\title{
Meaning in English
}

\author{
L2 attitudes, choices and pronunciation \\ in Norway \\ Ulrikke Rindal
}

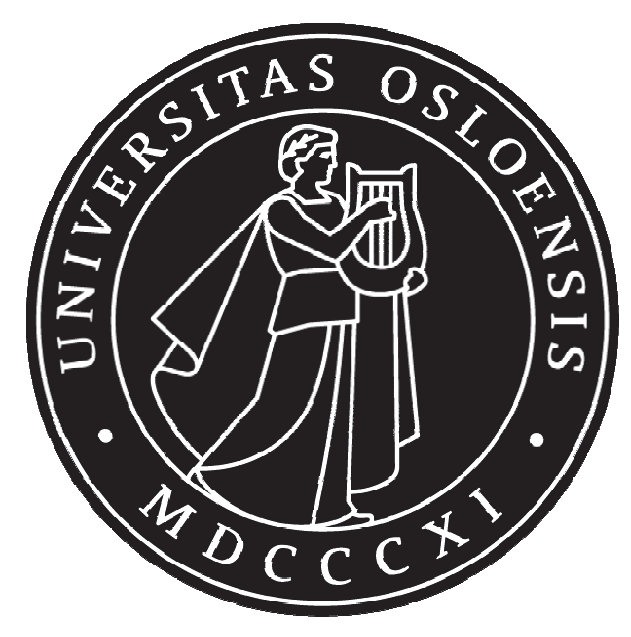

Dissertation for the degree of Philosophiae Doctor

Department of Teacher Education and School Research

Faculty of Educational Sciences

UNIVERSITY OF OSLO 



\section{Acknowledgements}

This thesis would not exist without the 100 students who patiently shared their English language practices with me. Thank you for allowing me to record you and for telling me about meanings. Thank you to their teachers for generously letting me into your classrooms.

I am very grateful to my supervisors. Thank you, Andreas Lund, for guiding me through everything and anything, for your faithful support and endless optimism. Thank you, Unn Røyneland, for academic and personal guidance, and for not letting me forget the Norwegian in the middle of all the English. Thank you, Paul Foulkes, for being so ambitious on my behalf from the very beginning. A big thank you to Andy Maul is also in order, for supervising me without getting credit for it.

Thank you to Stanford Linguistics, in particular Penny Eckert, John Rickford and the members of Sociolunch, for hosting me and for taking an interest in my work. Thanks also to Samy Alim's educational linguistics workshop for discussing and directing my data. Thank you to the Department of Language and Linguistic Science at the University of York for letting me listen and learn, and particularly to Huw Llewelyn-Jones for recording all the stimulus voices. Thank you, Caroline Piercy, for co-authoring one of the articles in this thesis and thereby drastically improving its quantity and quality, as well as the pleasantness of the process. Thank you, Lars Anders Kulbrandstad for conscientious, critical and encouraging mid- and final evaluation.

I would like to thank the Department of Teacher Education and School Research for funding and supporting my $\mathrm{PhD}$ thesis. I owe much of my research training to the National Graduate School in Education (NATED); many thanks to Track 2 for educational workshops and seminars, and specifically to Nils Otto Steen-Utheim, Toril Aagaard and Kenneth Silseth for post-seminar escapades. I am also grateful to the research groups SPRING, KIS and SISCO for academic and financial support. Thank you to the Text Laboratory at the Faculty of Humanities for developing a corpus for my data. Thank you, Are Burheim and Alex Iori for endless hours of transcribing and coding.

With such solid academic and administrative reinforcement, it goes without saying that any weaknesses remain my own. 
In addition, some people have to be thanked for just being there: Thank you, Maria Vetleseter Bøe, Fredrik Jensen and Margrethe Naalsund, for our invaluable collaborative avoidance of all things academic during lunch hours. Thank you, Kirsti Engelien, for emotional and nutritious support. Thank you, Inga Staal Jenset, for improving my office. Thank you, friends and family, for elegantly ignoring my rapidly deteriorating social competence.

Dear Christian, it is safe to say this thesis would not exist without you, not only because of your endless support and patience, but also because it was, after all, your idea.

Ulrikke Rindal, October 2012 


\section{Summary}

English is the language of international communication, and the status of English is increasingly characterised by speakers who use it as a second or later language (L2). People around the world appropriate and negotiate English into their local environments, which calls for research into new and developing Englishes. In an L2 environment such as Norway, with considerable English language proficiency and domain uses, we might expect an increase in language variation and with it the need to investigate social aspects of language use. This study therefore investigates the socially meaningful use of English among Norwegian adolescents.

The thesis reports a sociolinguistic investigation into L2 practices in a Norwegian English language teaching context, and is consequently highly interdisciplinary in nature; the theoretical and methodological framework is a composite of elements from both linguistics and education. Theory and methods are used related to language attitude and language variation research in sociolinguistics, as are frameworks related to the global development of English in applied linguistics. The study uses auditory analysis to investigate the pronunciation of English among Norwegian learners, and explores their language attitudes with an evaluation test combined with speaker commentary. Data from a questionnaire and interviews are used to discuss potential social meanings of L 2 choices. The thesis consists of three articles which form its foundation, as well as an extended abstract to create unity and discuss the overall themes and contributions.

The analyses show patterned variation in the L2 of Norwegian learners: English accents are socially evaluated by the participants, not only when these accents are spoken by native speakers of English, but also when these are appropriated by peers. The participants' pronunciation reflects the social reality in which they practice language, showing traces of social evaluations, pragmatic considerations, media influence and language competence. The overall results suggest that Norwegian learners can express local and individual identity through English.

This thesis shows that speaking English is a social practice for Norwegian adolescent learners. The acknowledgement of L2 as social has implications for educators concerned with English language teaching, who are encouraged to take social aspects into account when developing curricula and instructional design. 


\section{List of articles}

\section{Article 1:}

Rindal, U. (2010). Constructing identity with L2: Pronunciation and attitudes among Norwegian learners of English. Journal of Sociolinguistics, 14(2), 240-261.

\section{Article 2:}

Rindal, U. (forthcoming). Learner attitudes and L2 choices in Norway. Awaiting editor decision for Language Awareness

\section{Article 3:}

Rindal, U., \& Piercy, C. (forthcoming). Being 'neutral'? English pronunciation among Norwegian learners. In press for World Englishes. 


\section{Contents}

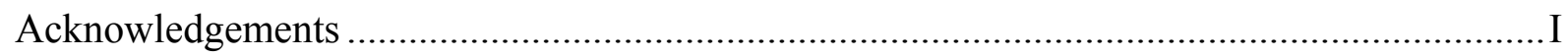

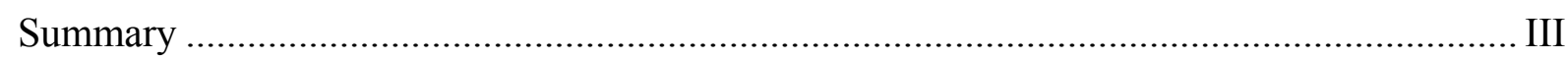

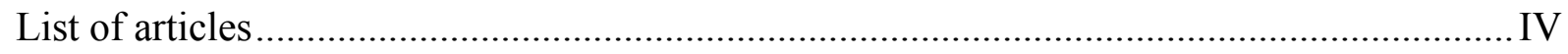

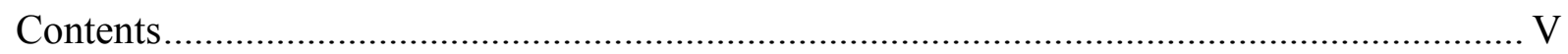

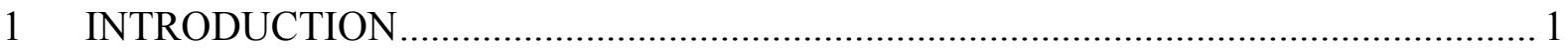

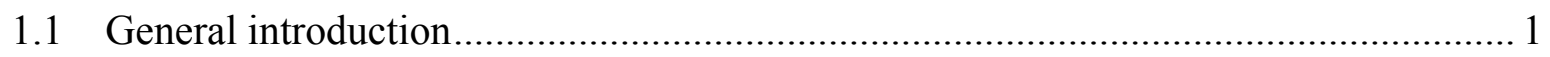

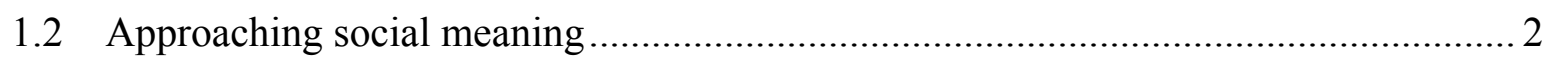

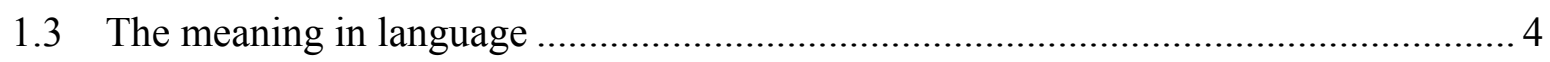

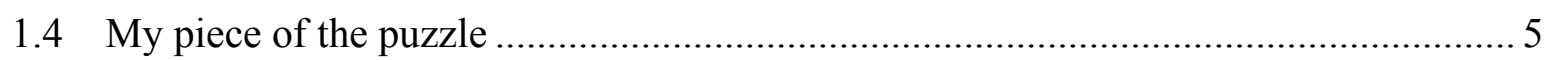

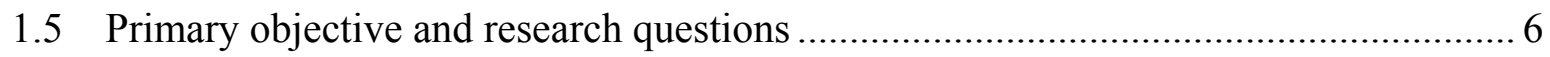

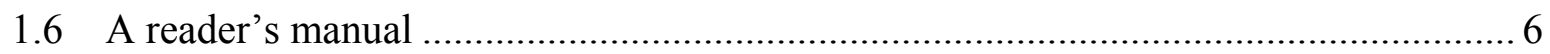

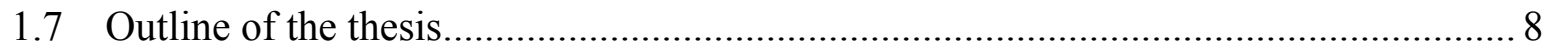

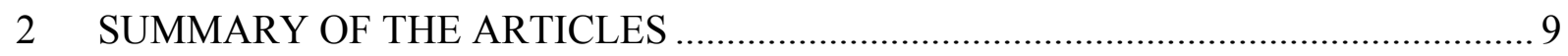

2.1 Article 1: Constructing identity with L2: Pronunciation and attitudes among Norwegian learners of English ..................................................................................... 9

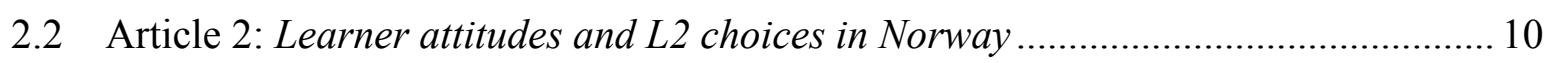

2.3 Article 3: Being 'neutral'? English pronunciation among Norwegian learners ........ 11

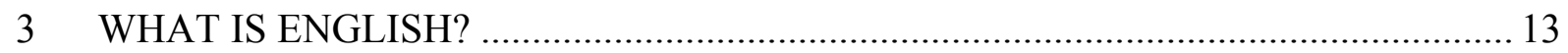

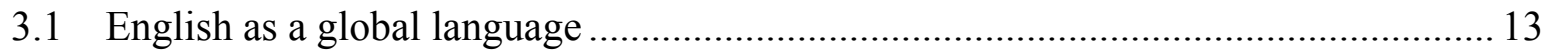

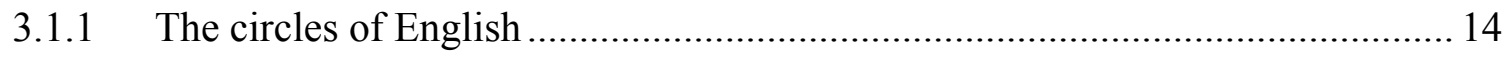

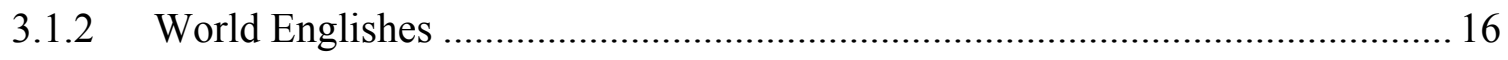

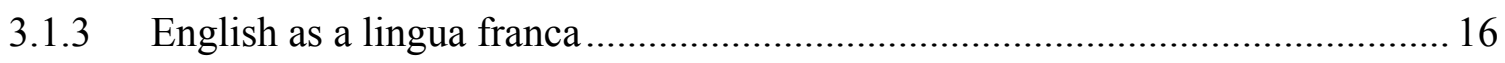

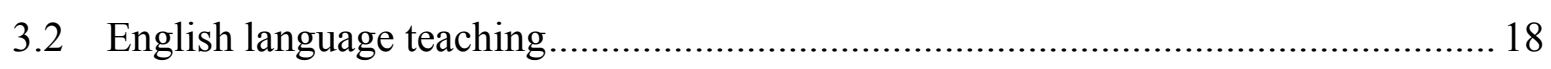

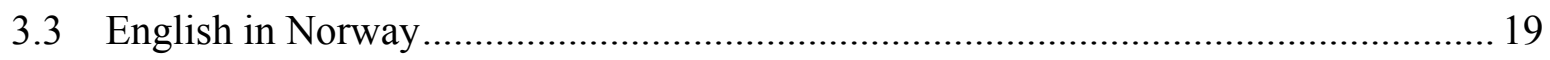

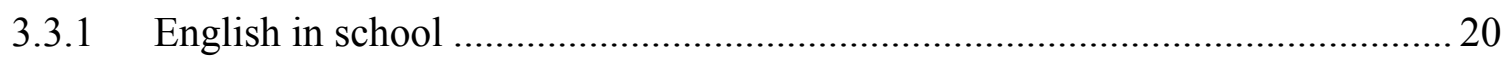

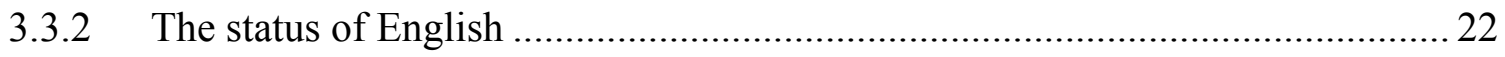

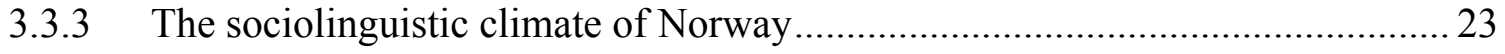

3.4 Variability as a functional design feature of language ........................................... 24

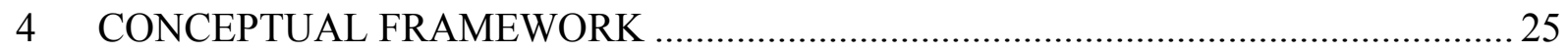

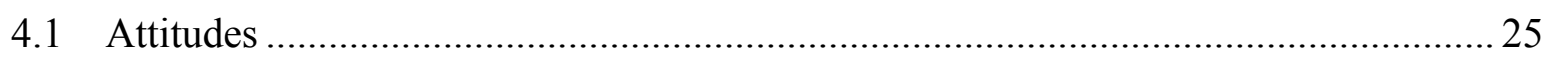

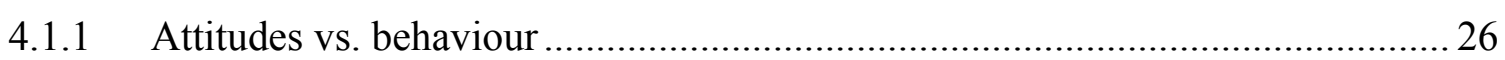

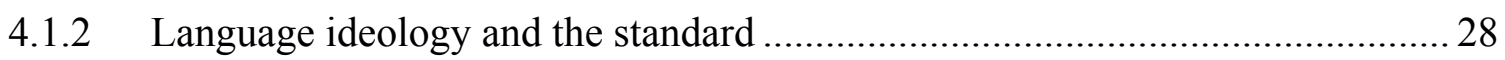

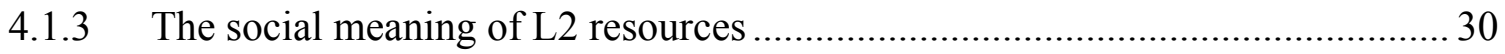

4.1.4 A note on the terminology related to L1 and L2 accents of English .................. 31

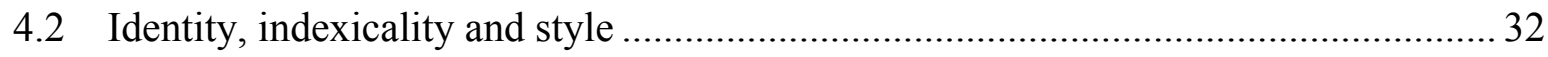

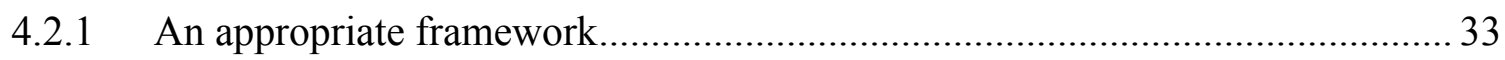




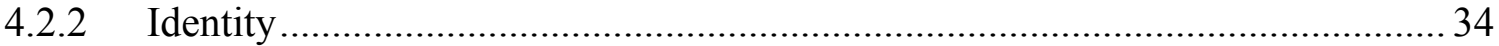

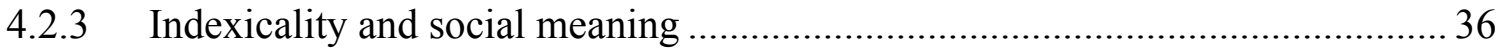

4.2.4 Language (learning) and identity in SLA .................................................. 36

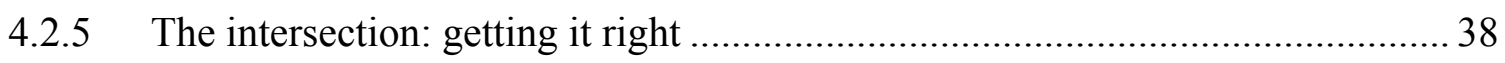

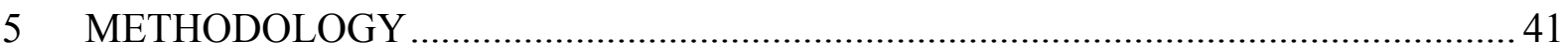

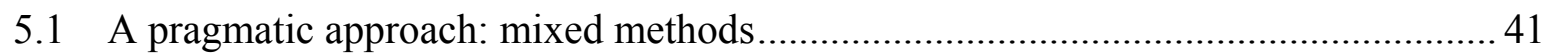

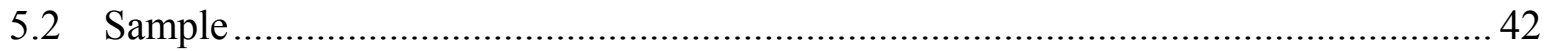

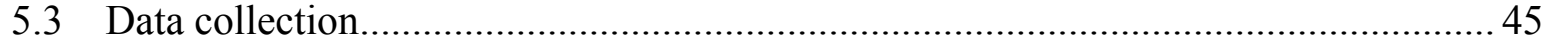

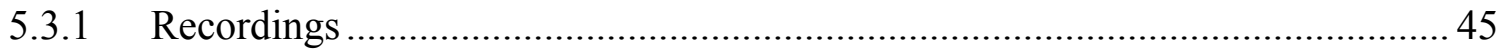

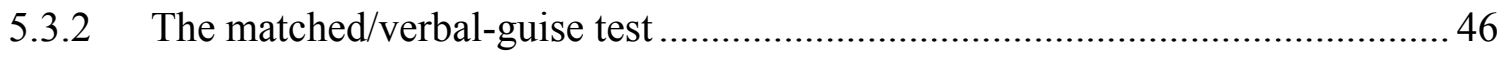

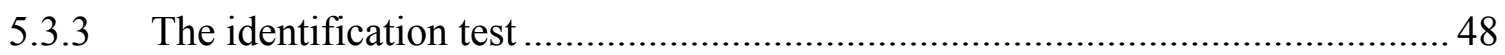

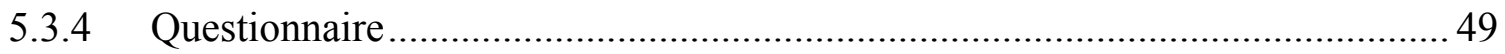

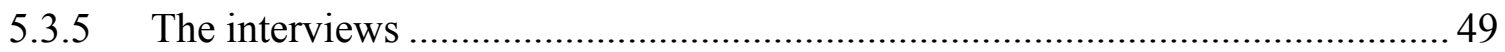

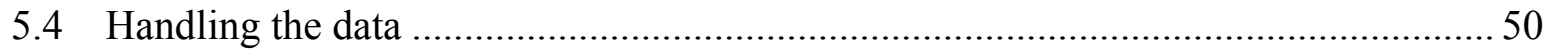

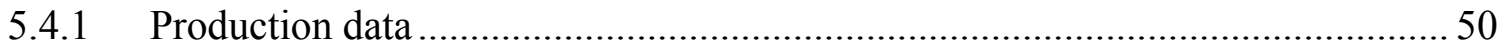

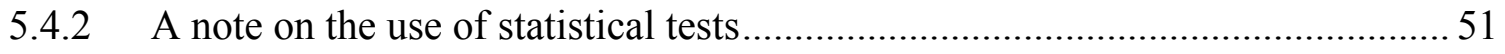

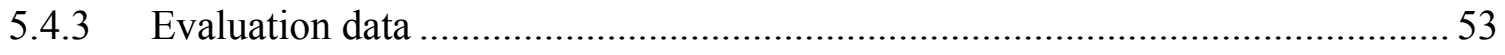

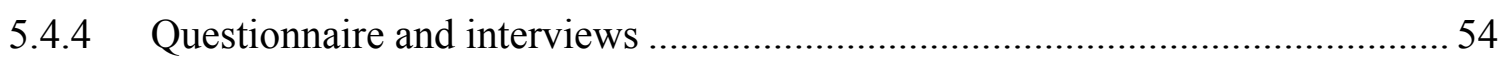

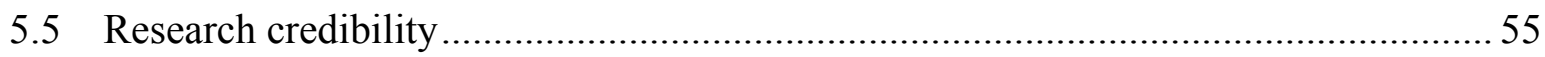

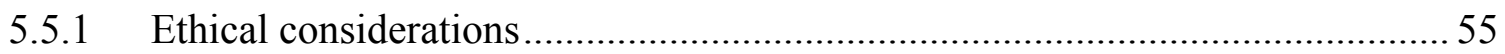

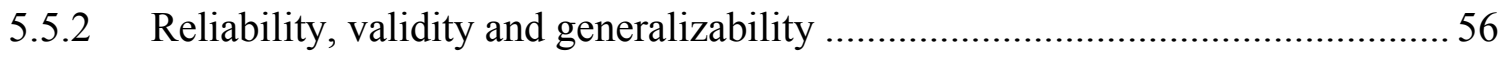

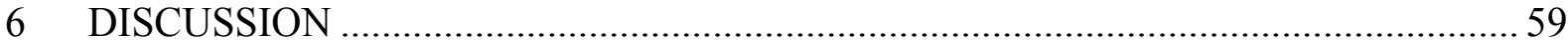

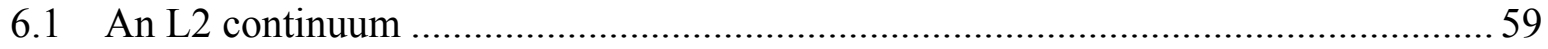

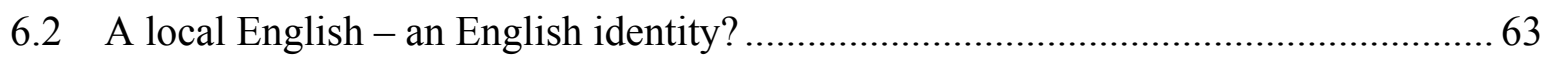

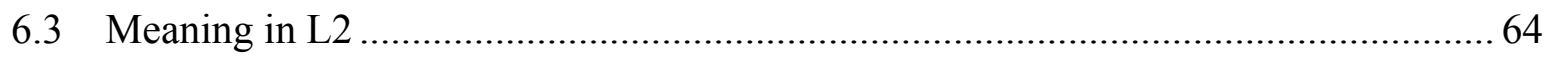

6.4 The future is social: educational implications and further research.......................... 66

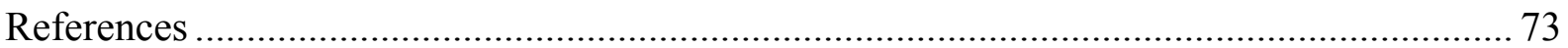

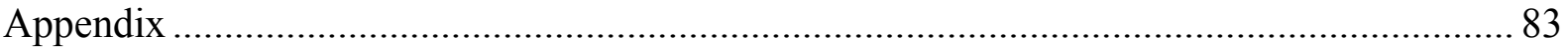

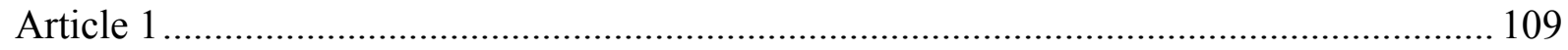

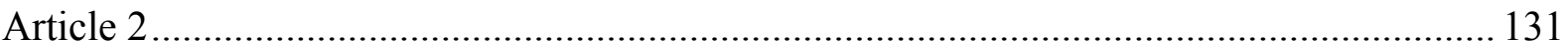

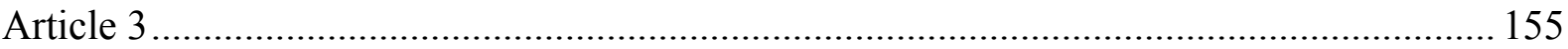

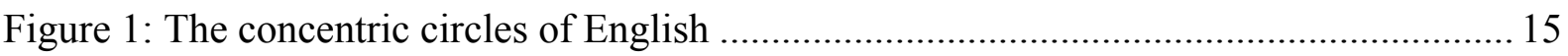

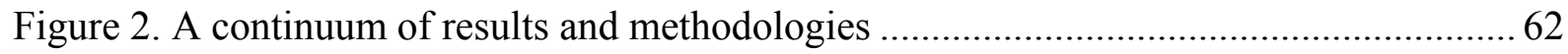




\section{$1 \quad$ INTRODUCTION}

\subsection{General introduction}

In an increasingly globalised world, English has become the foremost global language of communication. English is not only the result of a more economically, culturally and professionally interconnected world; it also provides the lingua franca that enables these connections. Because of this function as a transnational lingua franca, between one and two billion people are now learning English around the world (Crystal, 2003; Graddol, 2006), and the majority of English interactions involve only non-native speakers of English. The status of English in the world is increasingly characterised by those who use it as a second or later language, rather than by its native speakers (Kirkpatrick, 2010a). English is not merely spread around the world, but appropriated by speakers in different communities. The global development of English is thus characterised by variation and diversity, as more and more speakers negotiate English in their local environments. Speakers re-enact English to meet communicative and situational demands - in this way, the globalised English is being constantly localised through its use.

The global spread and local appropriation of English has elicited a growing body of research which describes and discusses the new and developing Englishes around the world (see e.g. Kachru, Kachru, \& Nelson, 2006; Kirkpatrick, 2010b). Most of this research has been conducted in postcolonial settings where English has official language status alongside one or more national languages and bilingualism has led to creole or indigenised Englishes. Furthermore, an emerging research trend is the investigation of English used as a lingua franca by non-native speakers. However, very little research focuses on environments where L2 speakers are proficient enough to use English as part of their linguistic and identity repertoire, but where English does not have status as an official second language or is used as a necessary language of communication. It is this sort of L2 environment which is the context for the study presented in this thesis.

In Norway, as in most other European countries, English has traditionally been labelled a foreign language; acknowledged for international travel, business and education, and taught at scheduled hours in the classroom. However, following increased out-of-school exposure and English language proficiency, English no longer feels foreign to Norwegians. Young Norwegians are frequent users of entertainment and social media, from which they are daily exposed to English. They travel to countries with both native and non-native speakers of 
English on holiday or to study. Almost half of the younger population (age 25-34) undertake higher education (OECD, 2011), where a considerable amount of written material and lectures are given in English (Ljosland, 2008; Schwach \& Dalseng, 2011). English language competence is increasingly considered a basic skill. And yet, Norwegians do not qualify as speakers of English as a second language as these are often described in the literature (e.g. Graddol, 2006); they are neither speakers of New Englishes in postcolonial countries nor immigrants to a native-English-speaking country, and English is not an official language in Norway. For young Norwegians, then, English is neither a first, second or foreign language. It is in this social reality, where English is characterised by diversity and variability globally, and without any clear status to its L2 speakers locally, that the participants of the present study practice English as L2. This thesis presents an overview of the L2 practices among Norwegian adolescents; their pronunciation of English, their L2 choices, and their social evaluations of the target language.

In an L2 environment with considerable development of language proficiency and domain use such as Norway, we might also expect an increase in language variation, and with it, the need to investigate social aspects of language. Importantly, although English is not an official second language or a necessary lingua franca for the participants of this study, English is still appropriated and negotiated to meet local demands. The three articles in this thesis investigate socially meaningful English language use on several levels, both related to established varieties of English and more local and individual constructions of the L2. Throughout the Extended Abstract, which summarises and discusses the results and implications of the three articles, I argue that speaking English is indeed a social practice, and that the social meaning of language should be the point of departure in the investigation of English language use in Norway. The acknowledgement of L2 as social has major implications for educational practices and how we think young Norwegians should learn English. The research presented here is therefore relevant to educators, who are encouraged to take social aspects into account when developing curricula and instructional design. Although this study clearly has educational concerns, sociolinguistic methods and perspectives seem the most appropriate for the purpose of investigating social meanings of language, and are therefore predominant in the approach applied here.

\subsection{Approaching social meaning}

By establishing correlations between linguistic variables and broad social categories such as sex, age and socioeconomic class, sociolinguist Bill Labov laid the foundation for the study of 
language variation (Labov, 1966). A more recent trend within variationist research is a focus on language practices against a wider system of social meaning, represented by for instance Penny Eckert (Eckert, 2004, 2012). According to this view, social categories like gender and class are not necessarily the source of social meaning, but also a result of social meaning, and so the focus should not be on pre-existing categories, but rather on the potential social meanings in variables and how these meanings are negotiated. The goal for this stylistic practice approach is "to understand linguistic practices and social meaning" (Quist, 2008: 43), aiming to describe what kind of meanings linguistic features can have, and how they can be used as a resource for self-positioning in a community of speakers. The point of departure in this thesis, reflected in the primary research objective in section 1.5 below, is social meaning, as in studies of language variation using a stylistic practice approach. In order to access potential social meanings in the English of Norwegian adolescents, the study first distinguishes the set of L2 features used by speakers, and investigates the associations to these features in the form of language attitudes. As what is most likely the first sociolinguistic investigation into L2 practices in a Norwegian English language teaching (ELT) context, it gives an overview of L2 sociolinguistic behaviour. From this foundation, the study investigates meaningful language use on several levels, investigating local negotiations of L2 styles.

Most of the research which is concerned with meaningful use of English linguistic resources focuses on native speakers (e.g. Eckert, 2000; Moore, 2010). The studies that do focus on English as a second language, are mostly concerned with the influence of English on the local language, for instance on the use of loan words and anglicisms and on domain loss (e.g. Graedler \& Johansson, 2002; Ljosland, 2008; Selback \& Sandøy, 2007). This is not a study about English in Norway in relation to Norwegian, but rather the appropriation of English by L2 speakers in Norway. It sees English in Norway not as foreign language elements that are imported into Norwegian, but as a language which is used by Norwegians and influenced by Norwegians. It is from this perspective that the study investigates the use of English among adolescents in an ELT context. This is done by investigating both the English pronunciation by Norwegian adolescents, with an auditory analysis of phonological variables, and their attitudes toward accents of English, with a speaker evaluation test and speaker commentary from a questionnaire and interviews. Data from the questionnaire and interviews are also used to discuss pronunciation in relation to attitudes, and potential social meanings of L2 choices. 


\subsection{The meaning in language}

In the social sciences, there is considerable agreement that language attitudes are dynamically related to language use; social cognition influences social action, and vice versa (e.g. Giles \& Coupland, 1991). Language attitude research can therefore provide explanations of language variation and change. This is the main reason for sociolinguists to investigate language attitudes. Language attitudes are also related to sociocultural norms, which constitute our communicative competence; language attitudes form a basis from which we listen to other people and process what they say in order to respond to their utterances. If language attitudes form a basis for other people's responses to our language use, language might be used to elicit a desired response from those people. Perhaps we want them to perceive us as formal, or we want to sound particularly intelligent, or we want them to trust us. Adjusting our language according to what we want language to do for us demands knowledge of both language forms and the sociocultural norms which accompany them.

The reciprocal relationship between language attitudes and language production makes research into this relationship especially relevant for educational research and language policy makers; knowledge about students' language attitudes and their impact on language use can inform educators to better meet students' needs and better plan school subjects. In the national English subject curriculum in Norway, considerable attention is appropriately paid to the global spread of English, and emphasis is given to intelligibility, pragmatic strategies and intercultural competence, rather than presenting the language of native speakers as a target. In line with the view of English as an international language, the syllabus does not offer learners any specific variety as 'correct', and no guidelines are offered related to pronunciation $(\mathrm{KD}$, 2006). Consequently, teachers are left with the responsibility to present and discuss with students the status and diversity of English, and to offer guidance related to personal language choices.

The relationship between social cognition and social action are not straightforward, especially not in contexts where language practices are less ingrained (Garrett, 2010), for instance an L2 environment. The relationship between attitudes and behaviour is discussed in section 4.1. The complexity of the English language domain in Norway is discussed at length in section 3 , but the approach applied to access these processes is briefly outlined here. 


\subsection{My piece of the puzzle}

The search for social meanings of L2 use among Norwegian adolescents requires investigations of the students' actual pronunciation, their attitudes towards different English accents, their desired pronunciation, and their opinions and attitudes about English in and out of school. Accordingly, this study is highly interdisciplinary in nature; the theoretical universe in which the research takes place is a composite of areas and theories from both linguistics and education, and the investigation uses various methods from both sciences. While the study is interested in language use and especially the social explanations of language use (sociolinguistics), it is also interested in the social relevance of language use (applied sociolinguistics), assuming that language educators will benefit from what research can say about speakers' perceptions and productions of language variation.

From sociolinguistics this study employs theories and methods related to language attitude and language variation research. From applied linguistics the study uses frameworks related to the global development of English, particularly perspectives which are concerned with the fluidity of language and bilingual speakers' rights to express national and individual identity through English. The shift in how language variation is viewed by many sociolinguists, from a reflection of a set of social macro-categories to a resource for social practice (cf. section 1.2), resonates in a shift in how language is viewed by some applied linguists, from fixed and static to fluid and dynamic. The research field that best incorporates the interdisciplinarity in this thesis, is that of sociocultural linguistics: "the broad interdisciplinary field concerned with the intersection of language, culture, and society", encompassing "sociolinguistics, linguistic anthropology, socially oriented forms of discourse analysis [...], and linguistically oriented social psychology, among others" (Bucholtz \& Hall, 2005: 586). This field resembles that of a broad definition of sociolinguistics, but ranges wider than sociolinguistics, both because the latter is "encumbered with a particular history of use" (Bucholtz \& Hall, 2005: 608), and because sociocultural linguistics better embraces the application of research in educational settings. This study applies sociolinguistic methods in educational environments in the attempt to answer not only how? and why? questions, but also so what?. Language variation research is central to answering these questions, as it may describe and provide explanations for what people think about other people because of how they speak, what impact these thoughts have for the language choices people make, and what effect these language choices in turn have on what people think - as well as what all this means for our society. 


\subsection{Primary objective and research questions}

The thesis has one primary research objective formulated as a main research question, and five sub-questions which contribute to elucidating the primary research objective. The primary research objective and main research question is:

What are the social meanings of L2 English as used by adolescents in Norwegian ELT?

The thesis as a whole is an attempt to answer this main research question. In order to do so, the results and discussions in the three journal articles and this Extended Abstract (EA) attempt to answer the following research questions (RQ):

1. What social evaluations do Norwegian adolescents make of English accents?

2. What characterises the pronunciation of English among Norwegian adolescents?

3. What characterises the relationship between attitudes, desired pronunciation and actual pronunciation?

4. How does English language use among learners relate to the status of English in Norway and the development of English as a global language?

5. What implications do social meanings of L2 have for English language education?

The first four of these research questions have been asked in Articles 1-3 in various forms, and have here been re-formulated to suit the thesis as a whole. RQ1 is treated in Article 1 and Article 2, while RQ2 is dealt with in Article 1 and Article 3. Article 2 and the EA consider RQ3, and RQ4 is discussed in Article 3 and the EA. Although RQs 1-4 are mainly handled in the separate articles and EA as reported here, they are also illuminated by the sum of these four texts. RQ5 refers to the educational implications of the results from the investigations in the study and is considered in all three articles, but mainly in the EA.

\subsection{A reader's manual}

This is an article-based thesis. During the last decade, the frequency of article-based doctoral theses in the educational sciences has increased, but the extended abstract genre is still under construction and there are few model texts. With only a short set of formal requirements as guidance, extended abstracts still come in a variety of forms, which is why a note on the purpose, structure and content of this particular EA is in order. 
Separately, each of the three journal articles attempts to answer one or more of the specific sub-questions given above. As a whole, and combined with the EA, they explore the primary research objective as formulated in the main research question. The main purpose of the EA is to create unity out of each of the articles and discuss the overall contribution of the research to the field. The content of the EA contributes to a framework for understanding the three separate article contributions, and central elements for this framework are the theoretical and methodological premises for the articles. Furthermore, discussions in the EA can present a more nuanced and elaborated argument than what the space-limited article genre can include.

Although the EA is mainly a framework for the three articles, it is also a reflection of the development of a doctoral project and my training as a researcher. An article-based thesis is limited by the publication process; not only is the article genre limiting as regards space, but the review process of publication might also to a certain degree restrict thematic content and structure. Furthermore, the most essential parts of the article-based thesis - the articles cannot be altered after they have been published, and therefore the processes of the research project become more transparent. Such traces of research processes are probably most apparent in the Methodology section.

The three articles are included at the end of this thesis, following the EA and appendices. The articles are given chronologically by journal submission and publication. The chronological order is also a thematic order: Article 1 considers both main themes of the thesis, attitudes and pronunciation, and extends its discussion beyond these themes to issues more immediate to the overall objective of the thesis as a whole, namely socially meaningful uses of L2. Article 2 and Article 3 explore and expand on one main theme each. The study as a whole consists of two data sets, of which Data set 1 was collected several years prior to Data set 2, and Article 1 is based on Data set 1, while Articles 2 and 3 are based on Data set 2.

Instead of a traditional literary review, I present in this EA a conceptual framework that lays out the theoretical premises for the thesis as a whole. This conceptual framework considers theoretical concepts which I use in the articles, such as attitudes, identity, meaning and style. Review of previous research is discussed throughout the Extended Abstract, mainly in section 4 , but the review should be regarded only as a supplement to the articles. The attempt to create unity out of each of the articles, and the discussion of the complexity and nuance of the empirical results, takes place throughout the EA, not only in the Discussion section. In line with this structural characteristic, the articles are summarised early in the text, 
as they are the foundation of the thesis and function as a backdrop for the discussions in the Extended Abstract. For the same reason it might be helpful to read the articles prior to the EA.

\subsection{Outline of the thesis}

As the foundation of the thesis, the articles are summarised immediately following this introduction to the thesis, in section 2. Following the article summary, in section 3 , is an account of the current status of the English language in Norway both in and out of the English language teaching context. This section marks the introduction to the framework for the three articles, as it presents the social reality in which the participants of the present study practice language. Section 4 defines and discusses the most central concepts used in the thesis, and outlines the general theoretical and conceptual framework. Section 5 is the Methodology section; it describes the methods used in the three articles, adding nuances which were left out of the articles due to spatial limitations. This section also discusses methodological considerations related to the overall thesis, such as validity, statistical issues, generalizability, ethics and limitations. The Methodology section is followed by the Discussion (section 6), which concludes the Extended Abstract by lifting to the surface the main contributions and implications of the thesis as a whole, and presenting directions for future research. 


\section{SUMMARY OF THE ARTICLES}

The foundation for this thesis consists of three articles which present empirical investigations of Norwegian adolescents' use of English, based on two data sets collected in English language teaching (ELT) environments. Details concerning the data sets and the methods and analyses applied in the three articles are described in section 5. This section briefly presents the main results and discussions of the articles.

\subsection{Article 1: Constructing identity with L2: Pronunciation and attitudes among Norwegian learners of English}

This article uses a combination of the methods used in Articles 2 and 3; auditory analysis of four phonological variables - Non-prevocalic/r/, Intervocalic/t/, GOAT and LOT, a matchedguise test with General American (GenAm) and Standard Southern British English (SSBE) stimulus, and a questionnaire and interviews. The article investigates English pronunciation among 23 Norwegian adolescents, as well as L2 attitudes and choices, and discusses negotiation of linguistic resources from English related to frameworks of stylistic practice and identity. I present four research questions in Article 1: 1) What is the dominant L2 pronunciation among the Norwegian participants and to what extent is there variation in L2 use across different formality situations?, 2) To what degree does L2 speech correlate with desired pronunciation?, 3) What social evaluations do the learners make of the available varieties of English?, and 4) How and to what extent are English linguistic resources used by Norwegian learners to signal style and identity?

The auditory analysis of speech produced in word list readings and conversational dyads showed considerable American English preference, indicating influence from English in the spoken media, which is dominated by American popular culture. Participants' pronunciation aligned with accent aims reported in the questionnaire; participants produced to a certain extent the variants found in their targeted variety of English. Results from the matched-guise test showed that SSBE was regarded as the most prestigious accent, rated considerably higher than GenAm for status and competence, as well as for linguistic quality. However, GenAm received the most favourable evaluation for social attractiveness qualities. As also suggested in Article 2, SSBE and GenAm seem to be assigned formal and informal functions, respectively. The results from the matched-guise test combined with speaker commentary suggest that the participants do in fact evaluate varieties of the L2, and make L2 choices based on these evaluations. In Article 1, I argue that Norwegian adolescents not only 
evaluate accents of English, but also their Norwegian peers based on which English accent they attempt to use. L2 use of English can thus index attitudes and qualities, and L2 speakers might make use of English resources in the construction of identity.

The article was published in Journal of Sociolinguistics 14(2), 2010.

\subsection{Article 2: Learner attitudes and L2 choices in Norway}

This article presents the social evaluations of native English accents among 70 Norwegian adolescents, and assesses the role of these evaluations for L2 pronunciation choices. The article asked 1) What social evaluations do Norwegian learners make of English accents?, and 2) How do language attitudes relate to L2 choices? Results from a verbal-guise test (VGT) showed that Standard Southern British English (SSBE) was regarded as the most prestigious English accent, rated considerably higher for status and competence, as well as for linguistic quality and social attractiveness, compared to General American (GenAm), Scottish English (ScE) and Leeds English (Leeds). An identification test showed that SSBE and GenAm were to a large extent identified correctly by the participants, while there was more confusion concerning the origin of ScE and Leeds accents. The participants reported their desired L2 pronunciation in a questionnaire: contrary to what could be expected from the VGT results, American English was the most popular accent aim (30/70), followed by British English (23/70). A large minority (11/70) reported to aim towards a 'neutral' accent of English. Participants gave reasons for these accent aims in the questionnaire and in focus-group interviews, and this speaker commentary corroborated with the VGT results: British English is assigned a formal function, related to competence and school, while American English is assigned an informal function. The rationale behind the participants' desired pronunciation seemed partly to be related to the social evaluations of the native accents: British English was preferred as target pronunciation because it was associated with e.g. formality and education, while American English was preferred because it was not associated with these qualities.

However, the discrepancy between the VGT results where SSBE emerged as an ELT standard, and the participants' reported target pronunciation which showed preference for American English (a discrepancy which is intensified by considerable American English preference in the production results presented in Articles 1 and 3), suggests that other factors and constraints apart from social evaluations are likely to have an impact on actual language behaviour. British English seemed to be a marked L2 pronunciation choice, conveying that the speaker is trying too hard, while American English was regarded as an easier and more accessible target, probably partly due to extensive exposure through popular media. 
Furthermore, these two most widely recognised native accents are associated with values and attributes that speakers might not always wish to convey. Instead, participants reported a desire to use a culturally and politically neutral accent of English, which would reflect their English proficiency without any cultural baggage. 'Neutral English' seemed to be a negotiation of resources from available accents of English.

In Article 2 I argue that the social meanings related to English accents are resources in the L2, and that Norwegian adolescents are first and foremost L2 speakers rather than predominantly L2 learners. However, language ideologies in the ELT environment are affected by other factors and constraints on evaluation, such as stance towards the evaluation and accessibility of linguistic and social resources. As an implication of the social evaluations of native English accents, I encourage critical distance in the use of target accents in English language teaching.

\subsection{Article 3: Being 'neutral'? English pronunciation among Norwegian learners}

This article describes the English pronunciation among Norwegian adolescents by presenting and discussing the results of an auditory analysis, and combining these with questionnaire and interview data concerning target pronunciation. The article is co-authored with Dr. Caroline Piercy, and the research questions we presented were: 1) What characterises the pronunciation of English among Norwegian learners?, and 2) How does English language use among learners relate to the status of English in Norway and the development of English as a global language? Seven phonological variables were investigated: Non-prevocalic /r/, Intervocalic /t/, Post-coronal /j/, BATH, LOT, GOAT, and Voiceless $t$. The auditory analysis of word list readings and conversational dyads among 70 participants showed considerable preference for variants that are also found in GenAm. The logical explanation for this result is that students are influenced by daily exposure to English language media, which is dominated by American English. However, despite considerable American English influence, there was considerable variation in the pronunciation of each variable. Statistical tests performed with a range of independent variables showed very little effect on production by school, teachers, gender or home language. The lack of variation across these social groups suggests that the participants constitute an L2 community with shared English linguistic practices, but also that there therefore is no obvious surface pattern in the variation.

Data concerning reported target pronunciation were combined with production data, and results showed that participants' realisation of variables aligned with their reported accent aim; participants produced to a certain degree the variants found in their targeted variety of 
English. Speakers who reported to aim towards a British English pronunciation ('BrE aimers') used lower levels of GenAm features than speakers who reported to aim towards an American English accent ('AmE aimers'), for all variables. Although the production results suggest an overall American English preference, most speakers used more than one variant for each variable, resulting in considerable intra-speaker variation. The overall speaker pattern, regardless of accent aim, is thus a blended use of variants from native English varieties, with some additional pronunciations, forming a hybrid and variable L2 accent. The strategy for participants who aimed towards a 'neutral' English accent ('Neutral aimers') seemed to be an attempt to avoid the associations related to native varieties by not aiming towards any recognisable English accent. Neutral aimers used less of the features found in GenAm than AmE aimers, but more than BrE aimers. Neutral aimers have thus positioned themselves in between in the traditional $\mathrm{BrE} / \mathrm{AmE}$ dichotomy. However, the pronunciation among these participants was also dominated by GenAm variants.

These production results reflect the L2 environment, where the role of English is characterised by transition and hybridity. Norwegian learners' L2 strategies seem also to be characterised by hybridity and negotiation, probably facilitated by the general acceptance of language variation in the Norwegian society. In this ELT context, factors such as media influence, language attitudes and language choices seem to better account for patterns in the L2 variation than frameworks such as World Englishes and English as a lingua franca, which are often used to describe the new uses of English in the world. However, similarly to the indigenised Englishes in postcolonial countries, English is also localised in this ELT environment, contributing to the increasing diversity in the development of English as a global language.

In Article 3 we argue that Norwegian students are proficient learners with a high level of L2 awareness, and that teacher education has a responsibility to make available recent and current research on English in the complex and globalising world, so that teachers can better meet the language needs among their learners. 


\section{WHAT IS ENGLISH?}

Rather than starting with a linguistic variable as in traditional variationist research, "it might be better to begin our search for sociolinguistic meaning by thinking about the range of social concerns held by a community of speakers" (Moore, 2012: 71). The framework of this thesis begins with a presentation of the social reality in which the Norwegian participants practice English, namely the global and local status of English as a language and as a school subject. Due to the interdisciplinary nature of this study, this section will present not only language paradigms, for instance World Englishes and English as a lingua franca, but also language learning traditions, for instance Communicative language teaching. As in the Extended Abstract in general, the aim is not to draw an extensive map of the field, but rather to navigate through the field and show where this study belongs. This is a field of many labels and abbreviations; a text box with a list of abbreviations used in this section is included here for reading facilitation. An extensive list of all abbreviations used in the thesis is given in Appendix 1.

CLT Communicative language teaching

EFL English as a foreign language

ELF English as a lingua franca

ELT English language teaching

ESL English as a second language

L2 Second (additional) language

WE World Englishes

\subsection{English as a global language}

The colonisation of the world during the last five centuries transformed a few European colonial languages - English, French, Russian and Spanish - into 'world languages', because they were used as vernaculars, exoglossic standards or lingua francas outside of their country of origin. With its large number of non-native speakers, the total number of English speakers is estimated to around 1,5 billion (Crystal, 2003), which is higher than for any of the other European world languages. However, a vast language does not automatically grant status as a world language; Mandarin Chinese, for instance, has more native speakers than English, but it is not used as a lingua franca except for in China and the Chinese Diaspora. It is because of its function as transnational lingua franca, that English has become the pre-eminent world language (Mufwene, 2010). English is at the centre of globalisation, it is both globalised and globalising: as a result of globalisation, English has become the lingua franca, but in addition, English provides the lingua franca that enables globalisation: 
If globalization is the means by which the world has become more interconnected, with our economic, cultural, political, professional and social spaces ever more entwined, then lingua franca interactions in English are the primary means by which those connections are made, by which human relations are maintained across conventional boundaries.

(Jenkins, Cogo, \& Dewey, 2011: 303)

In Norway, too, English surpasses all other languages in the establishment and preservation of economic, cultural, political and social relations with the rest of the world.

Following the global spread of English, the demography of English speakers is developing. For instance, analyses of international tourism show that three quarters of international visits are from one non-English speaking country to another (Graddol, 2006). This means that the majority of English interactions involve only non-native speakers of English. Learner motives, then, are increasingly instrumental and communication-oriented. The status of English in the world is increasingly characterised by those who use it as a second or later language, rather than the wealth and power of its native speakers. As a response to changing demands among learners of English, English language teaching is developing away from the traditional function of English as a 'foreign language' in the curriculum (Graddol, 2006).

\subsubsection{The circles of English}

The global community of English speakers has most commonly been represented by the concentric circles English, first introduced by Kachru (1985) (Figure 1). The inner circle represents the countries in which English is the primary (and often only) language, such as the UK, the USA, New Zealand, etc. The outer circle represents the countries in which English is identified as a 'second language' (abbreviated L2, but see comment about 'L2' vs. 'ESL' below). These are often former colonies, where English has official language status and is used as a lingua franca both with the outside world and among members of an elite class, for instance India and Singapore. In the expanding circle, English is identified as a 'foreign language' (EFL), and is recognised for international business, travel, education, etc. In expanding circle countries, English does not have official status, and is used as lingua franca with the outside world only. Norway has traditionally belonged to this expanding circle, along with e.g. China, Russia and Spain. 


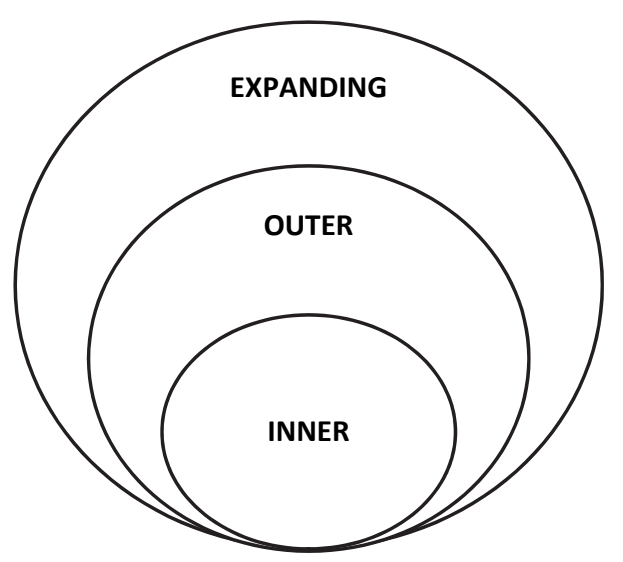

Figure 1: The concentric circles of English

This model has been criticised for being centrist, with monolingual English speakers in the centre. In a 1997 report for the British Council, Graddol argued that Kachru's model failed to portray the increasing importance of the outer circle, and the degree to which speakers in the expanding circle where becoming more like L2 users. In his report, Graddol listed a number of countries which he argued was part of a shift from EFL to L2 status due to increased intranational communication, for instance increased use of English in business and higher education. The list of 'transitional' countries comprised 19 countries, including for instance Argentina, Lebanon and Switzerland, and Norway was among them. Graddol also argued that "[t]he main distinction between a fluent EFL speaker and an L2 speaker depends on whether English is used within the speaker's community (country, family) and thus forms part of the speaker's identity repertoire" (Graddol, 1997: 11).

Graddol (1997: 10) defines 'L2', i.e. English as used by speakers who traditionally belong in the 'outer circle', as "a second or additional language [...] used in different contexts [...] a local form of English [or] international varieties". In comparison, speakers who traditionally belong in the 'expanding circle' are "people learning English as a foreign language (EFL)" (Graddol, 1997: 10). Conversely, it is problematic to assign labels of English status to speakers, because it is difficult to define such notions as language competence, language use and personal attachment to language (Engen \& Kulbrandstad, 2004). In his next report for the British Council, Graddol (2006), too, argues that it is increasingly difficult to define English speakers' bilingual status. Importantly, the label 'L2' is in this thesis used about any additional language, whether it is an official second language in a nation state or learned in school, and no matter the proficiency of the speaker. Accordingly, the Norwegian participants in this study are consistently labelled as 'L2 speakers'. When I nonetheless use 
labels such as 'EFL' and discuss Norwegian speakers' L2 status in relation to these, it is because these labels are extensively used in the literature which describes communities of English speakers and the development of ELT pedagogies in relation to these. For this purpose I use the label 'English as a second language (ESL)' to refer to the status assigned to 'outer circle' speakers, distinguishing them from speakers of English as a foreign language (EFL). As it happens, my discussion of the status of English in Norway (section 3.3.2) shows that these commonly used categories fail to include proficient Norwegian learners of English.

\subsubsection{World Englishes}

The World Englishes (WE) paradigm (Kachru, 1992; Kirkpatrick, 2010b) acknowledges the diversity in the global community of English speakers and recognises the legitimacy of modern English varieties, both native and non-native. WE research describes and discusses new Englishes, mostly creole or indigenised Englishes which have developed in postcolonial settings due to contact processes between English and local languages. However, although the WE paradigm allows for hybridity and appropriation, it is criticised for maintaining an elitist and centrist view (e.g. Graddol, 2006; Pennycook, 2005). In the concentric circles in Figure 1 above, English speakers' identity is constructed according to their nationality and its location within the circles. The inner circle represents native speakers who are speakers of core Englishes, and who are thus privileged over ESL speakers, who in turn are privileged over EFL speakers. Pennycook (2005: 15) argues that "as a sociolinguistic theory the WE paradigm is far too exclusionary to be able to account for many uses of English around the world".

\subsubsection{English as a lingua franca}

English as a lingua franca (ELF) is similar to the more established WE paradigm. Both paradigms explore the way English has spread and how non-native speakers, instead of using distant and unattainable native speakers as accent models, have formed new Englishes which express their sociocultural identities. The difference between the two paradigms is that many WE scholars still concern themselves with Englishes as (nationally) defined varieties, with native varieties as some kind of centre as reference for non-native varieties, while ELF scholars are more concerned with the fluidity and hybridity of language and want to abandon the traditional variety restriction (Jenkins et al., 2011). ELF is commonly defined as "an additionally acquired language system which serves as a common means of communication for speakers of different first languages" (Jenkins et al., 2011: 283). This definition does not exclude native speakers of English, and consequently ELF must be 'additionally acquired' by 
native speakers as well (granted they have a considerable advantage since they do not have to learn a grammar from scratch, but they have less experience with intercultural encounters and adjusting their language to other non-native speakers). Another definition of ELF excludes native speakers of English: “a 'contact language' between persons who share neither a common native tongue nor a common (national) culture and for whom English is the chosen foreign language of communication" (Firth, 1996: 240, emphasis in the original). This definition implies that all ELF speakers are EFL speakers, but today most ELF scholars separate distinctly between English as a lingua franca and English as a foreign language (Jenkins et al., 2011: 283-284, see Jenkins [2006a] for details).

The understanding of language as fluid and hybrid makes it difficult to attempt to describe ELF. Although an initial goal for ELF researchers was to codify a 'new' variety of English, this has now developed into an interest in the processes and motives of ELF communication:

the focus of research has shifted from an orientation to features and the ultimate aim of some kind of codification (an aim which, nevertheless, has not been dismissed out of hand), to an interest in the processes underlying and determining the choice of features used in any given ELF interaction. (Jenkins et al., 2011: 287)

Research into lingua franca English should thus be used as a perspective in ELT, not as another 'standard' or 'model' replacing native varieties. This is also a discussion among WE scholars: the term Global English is sometimes used to refer to an idea of a universal standard variety of English which can be used by all native and non-native speakers world-wide, (e.g. Crystal, 1997). This notion of a global Standard English has been regarded as utopian, since the majority of English speakers use indigenised varieties:

However 'global' the English language has become - in the sense of being a language that is spoken almost anywhere on our planet and permeates so many diverse domains of modern life $[\ldots]$ - it will continue to 'indigenize' everywhere, acquiring local characteristics in the same way it has done to date. (Mufwene, 2010: 47)

Mufwene argues that all use of English is embedded in local cultures and that English language diversity is only likely to increase. The evolution of English is not towards a uniform global standard, but rather to more diversity, due to variation in the appropriation by speakers. The term English as a global language refers to the spread of English around the world and should not be juxtaposed with the term Global English when this refers to the idea of a universal standard. Mufwene argues that this misled juxtaposition - "the myth of the emergence of a 'global English"' (Mufwene, 2010: 48) - is why some fear that English is 
endangering the vitality of other languages, believing that the global spread of English is a form of imperialism, reflecting global inequality (see e.g. Pennycook, 2005; Phillipson, 1992, 2003). The 'linguistic imperialism' discussion is a familiar one within applied linguistics, but it will not be addressed further in this thesis, since this study is not concerned with the relationship between English and Norwegian. In order to prevent terminology confusion, the term Global English is avoided altogether in this thesis.

\subsection{English language teaching}

English as a foreign language (EFL) and English as a second language (ESL) have coexisted within English language teaching (ELT) as the two main language learning traditions since the $19^{\text {th }}$ century (Graddol, 2006). The terms EFL and ESL describe the functions and status of English for communities of speakers, and consequently 'appropriate' pedagogies for these speakers. Traditionally, EFL has focused on language learning methodologies, and has endorsed learning about the culture and society of native speakers, and put these speakers forward as language models. ESL, on the other hand, acknowledges the society in which English is taught, but has commonly been restricted to two types of speaker communities: firstly, postcolonial countries, where local varieties have emerged from contact with local languages - the so-called 'New Englishes'. In these countries, the function of ESL classrooms is to teach a formal or standard variety, as opposed to the local English vernacular, and English is consequently often associated with certain domains, functions and elites. Second, ESL speakers are also immigrants to native-English countries, where many live in ethnic communities, and where bilingualism and identity issues become central elements in ELT.

In order to accommodate the development of English as a global language and changing demands among learners, departures from EFL and ESL have evolved in English language teaching, for instance communicative language teaching (CLT). CLT involves the teaching of English as an international language (Block, 2010), emphasising communicative competence and cultural pragmatic knowledge following the idea that language utterances have communicative functions in interactions. However, even though CLT places emphasis on 'intelligibility' and 'appropriateness', this can easily be, implicitly or explicitly, interpreted by for instance teachers or policy makers as intelligible and appropriate for native speakers. Consequently, even though focus is on communication and cultural competence, certain Englishes are still offered to learners as 'correct'. The role of native speakers as learner models in English language teaching has been questioned, not only for ESL speakers (e.g. Kachru, 1985; Phillipson, 1992), but also for speakers in countries where English is taught as 
a foreign language: scholars argue that native accents of English carry with them cultural identities that learners not necessarily want to adopt (e.g. Bex, 2008; Dürmüller, 2008). However, since education in nature is prescriptive, the lack of other alternatives often leaves native English accents as only valid targets for English learners.

These limitations are part of the motivation for ELF scholars, who suggest that the native speaker focus is due to lack of empirical research on lingua franca Englishes (Seidlhofer, 2001). The ELF paradigm attempts to challenge references and dichotomies such as L1/L2 and native/non-native. They argue that speakers negotiate and re-enact English to meet communicative and situational demands - in this way, the globalised English is being constantly localised through its use. In the ELF paradigm, ELT should reflect the needs of non-native speaker interactions, and consequently emphasise intelligibility and pragmatic strategies for intercultural communication. ELF researchers question the use of external models, especially American English and British English as prestige models (see Jenkins [2006a] for more); a condition for using English as a means of communication, is using lingua franca English and not native norms (Seidlhofer, 2010). Lingua franca English is typically characterised by linguistic properties and norms that are co-constructed and established in an ad hoc manner by speakers of different first languages in interactions where English is used to achieve a communicative goal (Seidlhofer, 2011). Lingua franca English will thus vary from speaker to speaker. The target model of English is a fluent bilingual speaker, who can communicate with other non-native speakers of varying proficiency, and still be able to express national identity in terms of English accent. The ELF contribution to education, then, is above all a perspective of English as variable and local:

a fundamental initial consequence of ELF research is the need to raise awareness of the relationship between language models (which are necessarily abstractions) and the variable nature of language in interaction. From this perspective, developing an ELF perspective in pedagogy entails above all, at least for now, the generating of an understanding among learners and teachers of the inherent variability (even instability) of human language in general and English more specifically. (Jenkins et al., 2011: 306)

ELF researchers thus attempt to make their research accessible to teachers so that they might (re)consider their beliefs about languages and English, and if necessary rethink their teaching practices.

\subsection{English in Norway}

As a nation with a history of navigation, Norway has had close ties with the English-speaking world for centuries. Following the internationalisation of business and education, as well as 
personal mobility and extensive exposure through the media, English has developed into a familiar language for Norwegians (Graedler, 2002; Simensen, 2011). English has been taught as a school subject since the end of the $19^{\text {th }}$ century, and increased in scale and significance until it became a mandatory subject for six years for all students in 1969 following the Primary and Lower Secondary Education Act (Simensen, 2011). English is now taught from year 1 (age six) and has its own syllabus separate from the other foreign languages. In addition to ten mandatory years of English teaching in primary and lower secondary school, students who attend upper secondary school have one more year of mandatory English and can choose English as programme subjects in their final two years. English as a mandatory subject throughout primary and secondary school follows an acknowledgement that Norwegians need language competence which will reach further than the Norwegian language (Simensen, 2011). English is by educational authorities regarded as a necessary skill to work and live in Norway, to communicate with non-native speakers around the world, and to communicate with native speakers and satisfy entrance requirements for tertiary education in native-speaking countries (KD, 2006). Although English does not have status as an official language, then, Norway has a de facto bilingual policy, and we can assume that all now living Norwegians have had some form of English language teaching (Graedler, 2002).

\subsubsection{English in school}

The escalation of English language teaching in Norwegian schools in the $20^{\text {th }}$ century resulted in an extensive demand for proficient teachers of English and English teacher educators. The British Council became central to meeting these demands, especially after getting its own representative in Norway from 1946. The British Council offered training to teachers through summer schools and courses both in Norway and in Great Britain. This training consisted of teaching methods and cultural content, as well as phonetics and intonation (Gundem, 1989; Simensen, 2011). Consultants were recruited from the British Council to the Ministry of Education and Church Affairs (today Ministry of Education and Research), and these influenced the development of teaching practices, training, language policy, curriculum material and exams. The British consultants had particular influence as regards pronunciation and intonation through curriculum material and teacher training, as well as classroom visits and introductions to cassette tapes with exemplary pronunciation (Gundem, 1989). British teachers also came to Norway to teach English during shorter periods of time. The training and teaching assistance from the British Council was gratefully accepted by a teaching 
community in dire need of English teachers, and lasted into the 1970s (Gundem, 1989; Simensen, 2011).

Although Norway is traditionally an EFL country, there have been considerable developments in Norwegian ELT in the last decades, seemingly apparent in the national curriculum from 2006, The Knowledge Promotion (KD, 2006). The English syllabus is considerably influenced by the Council of Europe's Common European Framework of Reference for languages and CLT perspectives, and secondary school ELT often includes general literacy skills and secondary materials which relate to another curriculum area, often social sciences, for instance global issues and human rights. However, even though materials and curriculum are increasingly non-centrist, learning about the culture and society of native speakers, especially in the UK and the US, is still endorsed to a certain degree (cf. section 4.1.2). The school syllabus does not present native varieties as target models to learners, but does not encourage learners to avoid native accents as targets either, or present an alternative to these. Without any pronunciation guidelines in the syllabus, we can assume that teachers of English only in varying degree allow for L1 characteristics and personal or national idiosyncrasy in learners' English production, even though the vast majority of these teachers are L2 speakers of English themselves. Furthermore, as a consequence of extensive influence from the British Council, it is reasonable to assume that an SSBE-like accent has been the de facto norm.

Although Norway has traditionally had more contact with the UK than with the US, American influence on the Norwegian society, particularly through import of popular culture, increased during the second half of the $20^{\text {th }}$ century and is now the dominant source of English influence (Graedler, 2002). Consequently, acceptance of American pronunciation in ELT has also increased. University students have been, and are still, introduced to SSBE and GenAm accents in courses which are part of their teacher education (University of Oslo, 2012). Furthermore, in my conversations with teachers and students of English during my years as both a student of English and an ELT educator and researcher, it seems as though there is general agreement that students in secondary school, at least in the 1980s and 1990s, were told by their teachers to choose British English or American English (implicitly the 'standard' varieties of these, see section 4.1.4) as target accent when speaking English in school. However, there is also general agreement that choosing British English was the wisest choice to make in the ELT situation, as successful appropriation of this accent could result in better grades and teacher preference. It might be that SSBE has kept its status as an implicit model of pronunciation, which is also indicated by the results in this thesis (cf. Article 2). 


\subsubsection{The status of English}

Outside of school, Norwegians experience massive exposure to English language media. Imported films and TV programmes are not dubbed but subtitled, and adolescents are confident users of new technologies and international media sources (ITU Monitor, 2009; Lund, 2006). Among their European peers, they are among the most proficient L2 speakers of English (Bonnet, 2004; Education First, 2011), and English is widely used in Norwegian business and higher education domains (Hellekjær, 2007; Homme Holstad, 2012; Ljosland, 2010; Språkrådet, 2011). Furthermore, the English language attitudes and behaviour presented in the three articles of this thesis suggests that English could indeed be part of adolescent speakers' identity repertoire. The language awareness and use demonstrated in this study suggests that English is very different from other foreign languages taught in school - and not at all a foreign language.

However, Norwegians do not qualify as ESL speakers according to how these are described in the literature related to learning traditions (e.g. Graddol, 2006, cf. section 3.2 above); they are neither speakers of 'New Englishes' in postcolonial countries nor immigrants to a native-English-speaking country. Furthermore, the ELT situation in Norwegian schools does not reflect the description of English as a lingua franca interactions, since English is not used as a necessary language of communication among Norwegians. Although upper secondary students, including the participants in my study, are a heterogeneous group with several home languages in addition to or instead of Norwegian, they all speak Norwegian. Most students would choose Norwegian as language of communication if possible - a constant headache for ELT teachers who practice monolingual classrooms. Even though business and academic domains do in fact experience increased use of English as lingua franca, research shows that Norwegians adhere to Norwegian if all participants share this L1 (Ljosland, 2010). Furthermore, English retains its separate identity as a discipline in school. Certain aspects of ELF, those in accordance with CLT, influence mainstream teaching, such as emphasis on intelligibility, pragmatic strategies and intercultural competence, but regardless of teacher and syllabus recognition of English as fluid and dynamic, the learning environment is still classroom-based and regulated by time tables and textbooks. Assessment is still carried out through national written exams with focus on writing texts with correct formal language and appropriate genre, or through oral exams with focus on presentation skills. This means that there is still a foreign language ambiance over English in Norway and in Norwegian schools. 
Consequently, the status of English in Norwegian ELT seems to be caught between language paradigms. What English is and thus how it is presented to Norwegian students seems to be in transition. We are moving away from an idea of English as a foreign language, but since Norwegian learners do not 'qualify' as ESL speakers, or lingua franca speakers, English remains in between. The status of English as transitional and variable does not apply only to Norway; in fact, variation and diversity seems to characterise the global development of English: as more and more speakers appropriate and negotiate English into their local environments, English is owned, and thus defined, by an increasing amount of speakers:

The crucial point here, then, is that it is not so much whether or not one is born in a particular type of community but rather what one does with the language. At the point of semiotic reconstruction, English users become native speakers of a new semiotic construction of language that cannot be predefined as a first, second or foreign language. (Pennycook, 2005: 31)

This perspective of English - as the world's preeminent language of communication, characterised by diversity and variability - is applied in this thesis. It is also the social reality in which the participants of this study practice English.

\subsubsection{The sociolinguistic climate of Norway}

Another characteristic of the participants' social reality is the public discourse on language in Norway. As discussed in Article 3, Norwegians are accustomed to considerable dialectal variation, and there is no explicit standard spoken variety in the form of a determined socially accepted linguistic variety. Whether or not there exists a perception among speakers of a superior norm is a much debated issue (e.g. Jahr \& Mæhlum, 2009), but either way, standard ideology in Norway is not prominent compared to other European countries (Røyneland, 2010). Norwegians are tolerant towards dialect use in the L1, as well as towards the general advance of English (Kristiansen \& Vikør, 2006a; Sandøy, 2007, 2011; Selback \& Kristiansen, 2006, but see Mæhlum \& Røyneland [2009] for a discussion about the limitations of the Norwegian dialect tolerance).

Furthermore, language issues and politics in Norway are largely interwoven (Kristiansen \& Vikør, 2006b; Trudgill, 2000). Language views reported by non-linguists have shown to align with those professed by scholars, suggesting that elite discourse and language politics are available to the public (Kristiansen, 2005, 2010; Kristiansen \& Sandøy, 2010). There is consequently a readiness among the Norwegians to discuss language matters (Kristiansen \& Vikør, 2006a), and this readiness has facilitated the execution of this research project: the participants were always willing to discuss English language choices with me, and 
I rarely encountered a student who did not have an opinion about English accents or L2 practices when confronted with such issues. Furthermore, the very public discourse on language in Norway strengthens the relevance of participant commentary on L2 issues in this study: we might assume that these students' views on English language resources and choices communicate a more public language-ideological discourse. The discussions of L2 ideologies and status in this study thus contribute to the sociolinguistic characterisations of Norway.

\subsection{Variability as a functional design feature of language}

The perspective described here in section 3, of English as fluid and variable, locally appropriated around the world, resonates well with the sociolinguistic view of language. Within sociolinguistics, language variation is seen as structured rather than random, and the origin and spread of variation is therefore investigated and plays a central role in the development of theory (Foulkes, 2006). Rather than regarding variability and diversity as a problematic interference of language patterns, sociolinguists view variation as a "functional design feature of language" (Foulkes, 2006: 654) and the central object of investigation. With this view of language variation as a backdrop, this study discusses the variability of Norwegian adolescents' English language use. If English no longer positions speakers within a nation state and within a concentric circle, the English language choices speakers make may reflect their positions or identities. This thesis concerns itself with such language choices. 


\section{CONCEPTUAL FRAMEWORK}

\subsection{Attitudes}

In social psychology and sociolinguistics, attitude is generally given the status of a social psychological construct, and has naturally been a much debated concept (Garrett, 2010; Kristiansen, Garrett, \& Coupland, 2005). Instead of defining attitude in detail, it might be more constructive to give a basic but perhaps slightly vague definition, and then elaborate and discuss the concept based on this definition, which is what this section does.

A much-used definition of attitude for language attitude research purposes is taken from Sarnoff (1970: 279): "a disposition to react favourably or unfavourably to a class of objects". This definition is elaborated by Garrett (2010: 20): "an attitude is an evaluative orientation to a social object of some sort, whether it is a language, or a new government policy, etc. and, as a 'disposition', an attitude can be seen as having a degree of stability that allows it to be identified". Having 'a degree of stability' does not mean that attitudes are not variable and dynamic: although attitudes are given the status of a psychological construct, they are not considered innate, but learned (Erwin, 2001; Garrett, 2010), from our social environment and from our personal experiences. Parents, teachers, friends, and the media contribute to the development of our attitudes, for instance towards language. Attitudes, then, are socially constructed, not entities that grow and exist independently in the individual.

As a psychological construct, a 'disposition', or 'evaluative orientation', attitudes are not directly observable, and can be difficult to access. They must be inferred from more obvious processes, such as statements, language behaviour, or spontaneous reactions to other people's language behaviour. It is these more obvious processes that this thesis refers to when discussing participants' attitudes; the evaluational reactions elicited with the verbal- and matched-guise tests, the participants' comments related to English accents, and their reported orientations towards English pronunciation which emerge in interviews. Some of these processes might access the individual's 'orientation' or 'disposition' more than other processes; the verbal/matched-guise test, for instance, is designed to elicit spontaneous reactions, while focus group interviews will probably restrain participants' reports due to the presence of peers and interviewer. This thesis does not value any of these processes more than others, but acknowledges that as complex concepts, attitudes can be manifested in different ways, and considering several manifestations can give a more complete or complex picture of attitudes. This acknowledgement is reflected in the research design of the present study, 
which investigates different manifestations of attitudes towards English, accessed through different methods.

\subsubsection{Attitudes vs. behaviour}

Regarding the structure of attitudes, there is some agreement on a tripartite structure of language attitudes into three components: cognition, affect and behaviour (Garrett, 2010; Kristiansen et al., 2005). The cognition aspect of attitudes encompasses beliefs about the social meaning of objects, such as for instance the belief that using a Standard Southern British English (SSBE) accent will signal qualities such as education and formality. The affective component concerns feelings towards the attitude object, for instance whether an SSBE accent is favoured or disfavoured by a speaker, or whether using this accent is approved or disapproved of. The third component, behaviour, concerns the relationship between social evaluation, i.e. the beliefs (cognition) and feelings (affect) related to the attitude object, and social action; for instance whether the evaluations of SSBE will in fact bring about the use of an SSBE accent. However, the links between cognition and affect on the one hand, and behaviour on the other, is problematic. Positive affect towards certain speakers does not mean that one necessarily wishes to behave like them; even though Norwegian L2 speakers of English find an SSBE accent attractive, they do not necessarily wish to imitate speakers of this variety. However, their beliefs and feelings about an SSBE accent might constitute part of their communicative competence, influencing the language choices they make when interacting with other speakers. The social meanings assigned to linguistic forms can thus function as resources in a language repertoire, not just among L1 speakers, but also among proficient L2 speakers.

However, there are likely to be other variables that are involved in determining language behaviour apart from beliefs and feelings related to linguistic forms. There are several possible levels of evaluations that determine language behaviour, for instance evaluation of the consequences of behaviour, beliefs about how others evaluate one's behaviour and the importance given to these evaluations (Ajzen \& Fishbein, 1980). What do teachers and peers think of me if I adopt an SSBE accent? Are their evaluations important to me? Will an SSBE accent give me a better grade? Such attitude factors can easily get conflicted with one another (Erwin, 2001); an SSBE accent is believed to be attractive and to invoke teacher approval and better grades, but it might also make an adolescent L2 speaker sound like s/he is trying too hard (cf. Article 2). These constraints from speakers' social surroundings also inform their L2 choices, as discussed in section 6 below. 
Furthermore, other variables involved in determining behaviour might be for instance whether the speaker feels s/he has the competence or ability necessary for desired language behaviour, or whether the language resources are available to the speaker. Although an SSBE accent is evaluated as attractive, these particular phonological forms might not be (or feel) attainable to the speaker. If acquiring SSBE forms is more of an effort due to limited availability or exposure, the attractive evaluation of an SSBE accent might be downplayed compared to a General American (GenAm) pronunciation model, or in the case of some of the participants in the present study: no native target accent at all. An SSBE accent might be considered an attractive accent, but this does not mean that Norwegian adolescents want to be associated with its speakers. In order to predict behaviour, attitudes are probably best investigated at the right level of specificity (Ajzen \& Fishbein, 1980); therefore, in addition to investigating cognitive judgements of native speakers of English, this study attempts to access cognitive and affective judgements related to participants' own use of English pronunciation, by requesting reports and explanations of L2 choices.

Kristiansen (2001) argues that it is the 'unaware' judgements of language which ultimately lead to language behaviour, not attitudes that people report when they are asked directly. Attitude research shows that people's behaviour generally does not mirror the attitudes they say they have (Garrett, 2010). 'Unaware' judgements can be elicited in evaluation experiments where participants do not know that language is the object of evaluation. Language attitude researchers therefore often avoid mentioning this fact to participants prior to the experiment. This concealment was not possible in the present study, where the stimulus in the evaluation tests was the participants' L2. Consequently, the language aspect was considerably more salient compared to investigations where the stimulus is the participants' L1. In the present study, it is very likely that there among the participants was an awareness of language as object of evaluation, even though any explicit mention of this was avoided (cf. section 5). Conversely, the relationship between level of consciousness related to attitudes and actual language behaviour is not as relevant when a second language adds to the complexity of the language domain: in the present study, second language behaviour is more closely linked to reported aims and motivations rather than the attitudes elicited with the verbal- and matched-guise tests (cf. section 6.1). 


\subsubsection{Language ideology and the standard}

In investigations of language attitudes towards varieties of English, Received Pronunciation (RP) or some other form of 'standard' British English has traditionally been evaluated as the most prestigious variety of English, associated with more competence and status than 'nonstandard' varieties of English, such as for instance Liverpool, Northern British English or Australian. The 'non-standards' have in turn been associated with more social attractiveness than competence, while Standard Southern British English (henceforth SSBE) has been regarded as socially unattractive. General American (GenAm) speakers have been evaluated moderately high for competence and prestige, but less so than SSBE speakers, and quite low for social attractiveness qualities (see Articles 1-2 for reviews of previous attitude research).

This attitude pattern was not only found in research several decades ago, for instance Ball (1983) or Giles (1970), but also in more recent attitude research, for instance in a survey conducted in collaboration with the BBC a few years ago (Bishop, Coupland, \& Garrett, 2005; Coupland \& Bishop, 2007), where SSBE-like accents were still found to be the most prestigious of native English accents. The authors of this recent research have attributed this attitudinal consistency to processes of social categorisation and language ideology. The participants in Bishop et al. (2005) were presented with accent labels, such as 'a standard English accent' and 'Queen's English', and asked to report associations related to prestige and pleasantness. The authors argue that this approach has elicited "the most abstract and most tightly structured language ideologies around accent variation in Britain [...] The method taps into stable conceptualisations of language variation, the traditional prejudicial myths that validate 'standard' varieties as prestige models" (Bishop et al., 2005: 152). However, even when such a conceptual approach is not applied in language attitude research, evaluation experiments seem to reproduce traditional conceptions of prestigious 'standard' varieties. For instance, in recent years, an increased number of studies have investigated attitudes towards varieties of English among non-native speakers, and these have also found that some form of 'standard' southern British English has been considered the most prestigious accent of English (cf. Articles 1-2). This is also the case in the present study: the Norwegian adolescents preferred SSBE over both GenAm and 'non-standard' varieties for status/competence and linguistic quality, thus retaining SSBE's status as an ELT standard. The participants thus reproduce stable conceptualisations of English accents and 'standardness', probably emanating from a standard language ideology (but see section 4.1.3 below about the attitudinal change related to SSBE as a standard accent). 
Ideology has been defined as "any constellation of beliefs or ideas, bearing on an aspect of social reality, which are experienced as fundamental or commonsensical and which can be observed to play a normative role" (Verschueren, 1999: vii). Language ideology, then, concerns the set of associations attributed to a language variety and its speakers (Irvine \& Gal, 2000). Similarities among speakers of the same variety, and differences between speakers of different varieties are often exaggerated, thus creating social groups which are assigned certain qualities and evaluated positively or negatively (Garrett, 2010). Language attitudes are influenced by ideologies, and by investigating language attitudes among Norwegian adolescents, this study taps into the language ideologies of these young L2 speakers and the social reality in which they practice language.

When qualities attributed to language varieties are idealisations made by people, attributing a standard quality to a language variety is thus a "consciousness among speakers of a 'correct', or canonical, form of language" (Milroy, 2007: 134). It is not an innate property of an accent to be prestigious, rather, its speakers are or have been prestigious, and these valueattributions have then been transmitted to the linguistic forms used by these speakers. The standardness assigned to language varieties is maintained through codification in dictionaries and grammars, thus granting them authority and legitimacy. Consequently, standard ideology is spread among speakers, and the variety is given supra-regional validity and a function as norm ideal for a larger society. These characteristics have often been given to GenAm and SSBE, thus granting them authoritative and official status world-wide. The canonisation of these varieties are still widely employed as models of pronunciation in English teaching across the globe (e.g. Locher \& Strässler, 2008), and are thus more comprehensible than more 'local' varieties of English (Milroy, 2007). In the English language syllabus for Norwegian schools, GenAm and SSBE are not explicitly presented as target accents (cf. section 3.3.1), but they are used as references to which other Englishes are compared. For instance, one of the competence aims for the students is to "give examples of other varieties of English than those that are used in the Anglo-American core area, and reflect on their distinctive character" $(\mathrm{KD}, 2006)$. On a similar vein, the Anglo-American core area is given as references in the presentation of cultural themes, for instance when students are asked to "discuss the way young people live, how they socialise, their views on life and values in Great Britain, the USA, other English-speaking countries and Norway" (KD, 2006). Because of the world-wide application of GenAm and SSBE as references for English pronunciation, these are also used as references (as codified by e.g. Cruttenden, 2008; Roach, Setter, \& Esling, 2011; Wells, 1982) in the data collection and analysis in this study. 


\subsubsection{The social meaning of $L 2$ resources}

Conversely, although GenAm and SSBE enjoy world-wide official status as 'standard' varieties of English, this does not necessarily mean that they always have standard functions. Since the label 'standard' is an ideological attribution assigned by speakers, the identification of standard variants must consequently take into account speakers' social evaluations (Coupland, 2009). In the verbal-guise test in the present study, GenAm speakers were evaluated similarly to the 'non-standard' speakers from Scotland and Leeds, while the SSBE accent was considered distinctly superior as regards to competence/status and linguistic qualities. However, although SSBE was attributed status as ELT standard, this accent was not a preferred choice for the participants. Other attitude manifestations than the cognitive judgements from the evaluation test showed that students did not necessarily want to assume this standard function - SSBE seemed to be, for some, too standard, and consequently, too marked. Interestingly, this SSBE reluctance reflects a tendency, both within the UK and internationally, of attitudinal change related to SSBE as a standard accent. Coupland (2009), for instance, suggests that because of language-ideological developments in society, an SSBE accent might not be such a favourable social investment; SSBE speakers are associated with 'posh', which entails an unreliable claim to superiority. In Norway, American English phonological variants become the more socially accessible choice, as considerable exposure has made these forms more familiar and thus less noticeable (cf. section 6.1).

The evaluations given to English linguistic forms among Norwegian adolescents are a part of their community's shared set of attitudes. From this set follows socially normative language expectations to other members of the community; due to the social meanings associated with English accents, L2 speakers are expected by peers to make language choices in line with the meanings in their social reality. The L2 choices students make in ELT situations become carriers of social meaning, which evoke attitudinal reactions from peers. Choices that counter the expected norms become noticeable: SSBE forms are less accessible than GenAm forms, and taking on SSBE forms is a marked L2 choice, associated with (excessive) educational aspirations. When Norwegian students choose a native target accent, they contribute to the maintenance of the attitudes and ideologies of English: they are themselves part of the construction of the social reality which is Norwegian ELT, and their language choices both represent and construe reality. Attitudes, then, are at once a socially structured and a socially structuring phenomenon. 


\subsubsection{A note on the terminology related to $L 1$ and $L 2$ accents of English}

Throughout this thesis, the labels Received Pronunciation (RP), Standard Southern British English (SSBE), British English, General American (GenAm) and American English are all used to refer to English accents. This diverse terminology use is not coincidental. Southern varieties of English in England are distinctly separated from Northern varieties in England by a selection of phonological features (Foulkes \& Docherty, 2007). The pattern typical for southern varieties is part of the idealised middle class pronunciation norm for England, often labelled $R P$. In this thesis, I use $S S B E$ rather than $R P$, as "a modern equivalent" of RP, "an accent of the south east of England which operates as a prestige norm there and (to varying degrees) in other parts of the British Isles and beyond" (International Phonetic Association, 1999: 4). SSBE is not only more accurate than RP, since few speakers actually speak RP (Wells, 1982: 279), but by using it I also avoid the particular history of the use of RP, and its connotations and reputations (e.g. Coupland, 2009; Garrett, Selleck, \& Coupland, 2011). Similarly to SSBE, GenAm is "regarded as a variety which transcends regional divides" (International Phonetic Association, 1999: 4). SSBE and GenAm are used in this thesis when referring to the stimulus voices in the verbal- and matched-guise tests, produced by linguists acquainted with the demarcations of these reference accents. In Article 1 the label $R P$ was used for this purpose, but for simplicity this is also referred to as SSBE in the Extended Abstract. SSBE and GenAm are also used when referring to these as native English accents available as references to L2 speakers. However, when the status and prestige of RP as a supra-local standard accent has been discussed in the literature, it is often related to exactly its particular history of use, and therefore the label $R P$ is used when referring to this previous literature.

The demarcations of these varieties and their labels can be baffling for any scholar, let alone the students of English in Norway. It was important that the labels presented to the participants would be familiar to them. Following a series of pilot studies and conversations with students comparable to the participants in this study, I chose to present the labels American English and British English as reference accents in the questionnaire, since most students would not know the labels RP or SSBE. It has always seemed to me, and it still does after working with the data presented in this study, that American English used by Norwegians generally refers to a GenAm accent. Similarly, SSBE, or alternatively RP, is by the participants simply referred to as 'British English', or often just 'English'. Very few participants have shown recognition of the extensive variation that exists within what scholars label British English. Support for these assumptions can be found in the data reported in this 
thesis. For instance, there is no trace of any patterned use of 'non-standard' features in the production data. Furthermore, results from the identification test reported in Article 2 show a general confusion as to the origins of the Leeds English and Scottish English voices. Also, when asked for reasons for choosing 'British English' as preferred target accent in the questionnaire and interviews, participants reported reasons similar to the social evaluations of SSBE which emerged in the verbal- and matched-guise tests. Because American English and British English are familiar labels to the participants, and thus used as labels in the questionnaire and interviews, these are also used as labels when referring to the accent aims reported by the participants, who are consequently referred to as American English (AmE) aimers and British English (BrE) aimers.

Related to the participants' actual production, I did not want to describe participants' L2 pronunciation as GenAm and SSBE, because although their variants seem to be chosen from these varieties, the participants' produced variants are not native variants of English. In Article 1, I simply referred to both the participants' L2 variants and the varieties they aimed towards, as British English (BrE) and American English (BrE), so as not to confuse them with more rigid demarcations of 'standard' native variants or varieties. Our strategy in Article 3, however, was to describe participants' variants in relation to the reference accent, for instance 'variants also found in GenAm', and I have extended this practice to the EA.

\subsection{Identity, indexicality and style}

Although this is not a study primarily about identity, this concept is, alongside style and indexicality, central in how this thesis understands the construction of social meaning. There are many definitions of identity in the social science literature, and there seems to be much uncertainty about its definition. Some use many labels for the same construct, while some use the same label - identity - for many constructs. Because it is such a much-used term, an account of what identity is in this thesis is in order. As in most of this Extended Abstract, this section, too, is characterised by the interdisciplinary nature of the study. Both sociolinguists and SLA scholars are concerned with identity as a subject for investigation. Within sociolinguistics, it is believed that language is used to express (in some way) identity (in some form). In line with such a belief, SLA scholars acknowledge that learning a new language has consequences for the identities of the language learners. However, the view of identity applied in SLA research (e.g. Block, 2007; Menard-Warwick, 2005; Norton, 2000; Norton \& Toohey, 2011 ) is not entirely appropriate for the present study (cf. section 4.2 .5 below). Instead, the views of identity professed by some sociolinguists seem to be a better match. 


\subsubsection{An appropriate framework}

The perspective of identity in this thesis aligns with that of sociocultural linguistics; i.e. a perspective of identity that agrees with the relationship and dynamics between language, culture and society (cf. section 1.4). As in my approach to attitudes presented above, I use a broad definition of identity as a basis for a more detailed and precise description of the concept identity. In their account of an identity framework appropriate for application in studies of language variation, Bucholtz and Hall (2005) offer such a broad definition of identity. Drawing on various subfields, mainly from social psychology (e.g. Giles, Coupland, \& Coupland, 1991; Tajfel \& Turner, 1979), linguistic anthropology (Ochs, 1992; Silverstein, 1979, 1985), and sociolinguistics (Eckert \& Rickford, 2001; Le Page \& Tabouret-Keller, 1985), identity is defined as "the social positioning of self and other" (Bucholtz \& Hall, 2005: 586). Below I present the principles of an appropriate framework of identity, as summarised by Bucholtz and Hall, and account for the view of identity in this thesis by focusing and expanding on some of these principles, relating them to this study. Unfortunately, the scope of this thesis is not wide enough to present a precise and extensive discussion about the construct identity. Identity is only one out of several constructs and concepts which combined constitute the theme of this research, and the theory presented here is thus limited to what is needed in order to conceptually position the thesis within the vast range of work on identity. I offer here the view of identity which forms the backdrop for discussions of identity in section 6.2 , and which also forms an appropriate basis from which to discuss style and social meaning - a discussion which is central in the view of language in this thesis.

The view of identity in this thesis resembles that of many sociolinguists concerned with social aspects of language variation (e.g. Androutsopoulos \& Georgakopoulou, 2003; Auer, 2007; Coupland, 2007; Llamas \& Watt, 2010; Omoniyi \& White, 2006), and can be summarised in the following five common positions, here adapted from Bucholtz and Hall (2005):

1. Identity emerges in social interaction, and is therefore essentially a social and cultural phenomenon

2. Identities are correlated with both broader social structures, as well as local cultural positions and temporary stances and roles

3. Identities are indexed through linguistic structures, for instance associations between linguistic forms and social meanings

4. Identities are constructed through several aspects of the relationship between self and other 
5. Identity processes can be both intentional and deliberate, or habitual and less aware, therefore they can change across interactions

Since this thesis is particularly concerned with the use of linguistic resources in the negotiation of meaning, this section will focus particularly on the third position, relating to indexicality and the semiotic links between linguistic structures and social meanings.

\subsubsection{Identity}

In this thesis, identity is viewed as emergent in local discourse rather than as a stable and static structure within the individual mind. Identity is thus predominantly a social phenomenon, constructed in relation to others. The social and emergent characteristics of identity are in line with poststructuralist theories of language, proposed for instance by Russian literary theorist Mikhail Bakhtin (e.g. 1981, 1986), who argued that the meaning in language forms is not independent of its speakers; language is social and meaning is created by speakers in dialogue. Bakhtin describes language as already imbued with the meanings of previous users: "overpopulated - with the intentions of others" (Bakhtin, 1981: 294), but argued that speakers could (with difficulty) express own meanings with previously used language forms. Other poststructuralists, such as feminist scholars Chris Weedon (1987) and Judith Butler (1990), follow in the footsteps of Bakhtin and remove themselves completely from a view of a stable and actual identity; drawing on Foucault (1980), they understand identity to be constructed through discourse. The subject is dynamic and changes over history and social space as people are constructed and construct themselves.

The development from a view of identity as a stable entity to dynamic and emergent reflects a general development from modernity to late modernity. This development is characterised by increased social complexity and cultural reflexivity, changing limits for trust and risk, detraditionalisation and deinstitutionalisation (Beck, 1999; Giddens, 1991; Harvey, 1989), and as regards identity, focus is moved from large groups to the individual's relations to these groups - how the individual presents him/herself and his/her identity. This development is also apparent within language variation research, more specifically in the criticism of traditional variationist sociolinguistics for looking at identity one-dimensionally as a reflection of relatively stable macro-level social categories (cf. section 1.2). In more dynamic approaches, identity is constructed and negotiated.

In the sociolinguistics of style (Auer, 2007; Coupland, 2007; Eckert \& Rickford, 2001), language is a practice - an activity of creating social meaning. Linguistic variables do not have fixed meanings, but speakers give them meaning through the construction of his or 
her style. Speakers pick from a range of linguistic resources to construct new meanings or change old meanings. Variables have potential meanings which are interpreted by the speaker and then the variable is used on a local level and mixed with other resources - the combination of these variables constitutes the speaker's constructed style. Style, then, is "a clustering of linguistic resources, and an association of that clustering with social meaning" (Eckert, 2001: 123, but see also: Bucholtz, 2010; Coupland, 2007; Maegaard, 2007; Moore, 2004; Podesva, 2007; Quist, 2005). People can use resources in a variety of combinations to generate new meanings or reorganise old meanings. Stylistic practice concerns "adapting linguistic variables available out in the larger world to the construction of social meaning on a local level" (Eckert, 2004: 44). In Norway, for instance, a range of English language resources are (more or less) available to L2 speakers; these resources can be imported into the Norwegian classroom and combined in new ways, so that their meanings are renegotiated and reassembled into a style of English that is socially meaningful to peers (cf. section 6).

Scholars concerned with stylistic practice often use persona to describe that 'something' that characterises an individual's language practices and which is socially recognisable on a local level (e.g. Eckert, 2004; Quist, 2005). A speaker combines several variables (which in combination is style) to create a socially recognisable persona. Persona, then, is the individual's stylistic presentation of self. The construct of persona seems thus to align with (or at least fit into) the framework of identity presented here, and indeed, 'persona' could be a more manageable term than the much-used 'identity' to describe speakers' local appropriation and negotiation of linguistic forms to show a desired version of themselves. When 'persona' is not used in the articles or more extensively in this Extended Abstract, it is mostly because a discussion of speakers' personae entails a detailed focus on the individual, which is beyond the scope of this thesis. Personae are best investigated and presented through ethnographic methods (as in e.g. Eckert, 1989; Moore, 2010; Quist, 2005), in order to access the complexities of stylistic practices and styles. The same might be said for identity and style; this thesis is not first and foremost a study of speakers' L2 identity or L2 style, but it investigates aspects of stylistic practice. Importantly, there are constraints related to speakers' language practices, particularly in an L2; not only do social and cultural issues in the ELT context or in the larger society delimit and structure speakers' language choices, but limited linguistic competence may also restrict the appropriation of language forms (cf. section 6). This thesis investigates meaningful language use on several levels; reflected and projected, as well as constructed and negotiated (cf. the second position in section 4.2.1 above). 


\subsubsection{Indexicality and social meaning}

To account for how speakers may exploit the semiotic links between linguistic forms and social meanings is the mechanism of indexicality (Ochs, 1992; Silverstein, 1979, 1985). A linguistic feature can index particular qualities or meanings. For instance, using features from Southern Standard British English can index formality, because SSBE features have become socially recognised as indexing formality following continuous production and reproduction of these features (cf. Agha's [2003] 'enregisterment'). These associations and meanings are not fixed; language forms possess potential meanings, which can be activated by speakers in a specific context for a specific purpose (Eckert, 2008, 2012; Moore, 2012). Because linguistic forms have the potential to take on meaning, all language variation is not necessarily socially meaningful or consciously controlled, and the same features can take on different meanings. For instance, an SSBE feature can index formality in one context for one speaker, and arrogance in another context for another (or the same) speaker. Either way, linguistic variables can be exploited for social meaning.

Linguistic forms derive their associations and meanings from language ideologies, which can be accessed by investigating language attitudes, as argued in section 4.1.2 above. For instance, potential meanings of English phonological variants can be found in Norwegian L2 speakers' evaluations of the people who use these variants: their impressions of these people's beliefs, values and qualities, their evaluation of these impressions, and their potential alignment with these people and these impressions. The constellation of potential meanings in linguistic forms constitutes an indexical field: "An indexical field is a constellation of meanings that are ideologically linked. As such, it is inseparable from the ideological field and can be seen as an embodiment of ideology in linguistic form.” (Eckert, 2008: 464). Social meaning is therefore best explored by investigating both the use of linguistic forms, and the ideologies related to these linguistic forms, as in this thesis.

\subsubsection{Language (learning) and identity in SLA}

The modernity to late-modernity shift in viewing identity not as a stable entity, but as dynamic and social, is also reflected in the second language acquisition (SLA) discipline, which deals with language learning in particular. SLA scholars, too, seem to draw on poststructuralist theories of language when theorising identity in relation to SLA research (e.g. Block, 2007; Menard-Warwick, 2005; Norton \& Toohey, 2011). They, too, seem concerned with the social context of the individual, and understand identity as changing over time and space. Drawing on Bakhtin, SLA scholars argue that language learning is not an 
individual process where language forms are internalised, but rather a process where the learner attempts to create meaningful dialogue with others so that they can participate in speech communities (Norton \& Toohey, 2011). SLA research also draws on Pierre Bourdieu, a French sociologist and poststructuralist who was concerned with the politics of language and the power and 'rights' of language forms (Bourdieu, 1977, 1991). Bourdieu argued that language forms were ascribed value and meanings depending on the cultural capital - the knowledge, credentials and ways of thinking - of the person who uses them. Participants in an interaction will have different 'rights' to speak, depending on their ascribed value. Language is thus a social and political practice, and the 'correct' language forms can be an asset. The power aspect of the poststructuralist language view is central to language educators, because they believe that educational practices can give learners access to language forms which can give them power, granting them access to social networks where they will get the opportunity to speak. Educational practices can offer learners more powerful positions, and assist in transforming them: "education can lead to individual and social change" (Norton \& Toohey, 2011: 417).

Another relevant theorist for SLA research is psychologist Lev Vygotsky. While Bakhtin and Bourdieu represent a poststructuralist theory of language, Lev Vygotsky (1978, 1987) represents a sociocultural theory of language learning, alongside contemporary scholars such as Linell (2009) and Lantolf (2006). Within this school, learning is a social process, and language is a symbolic, cultural and dynamic tool that can be used for learning. People are situated historically and culturally, and use cultural tools when participating in cultural activities. Many educational scholars draw on sociocultural theories, and they emphasise the activities and tools offered to learners.

SLA scholar Bonny Norton has had a central role in theorising identity related to language learning, and has introduced the constructs investment (Norton Pierce, 1995) and imagined communities and imagined identities (Kanno \& Norton, 2003; Norton, 2001). ${ }^{1}$ Language educators are concerned with motivation for language learning, and the impact of learners' identity for motivation (e.g. Dörnyei, 2001). While motivation is a psychological construct, investment is a sociological construct, which complements motivation. Investment concerns the relation between an individual's commitment and desire to learn a language and the practices of the classroom or community in which the learning is situated. The construct draws particularly on Bourdieu and his cultural capital: if people believe they will increase

\footnotetext{
${ }^{1}$ The term ‘imagined communities' was first coined by Anderson (1991).
} 
their cultural capital by learning a particular language, they will commit to learning it. The theoretical constructs imagined communities and imagined identities refer to how language learners can imagine who they can be and which communities they can be part of in the future, be it local, national or transnational communities. How a learner imagines himself or herself in the future has an impact on his/her investment in learning the target language.

\subsubsection{The intersection: getting it right}

However, even though SLA scholars often theorise identity similarly to sociolinguists, their discussions often concern the identity of the speaker as learner, and the challenges this learner is faced with when appropriating another language than one's own. These challenges are often related to new citizenship and power relations between home and target language and culture. The research focus in SLA seems often to be language acquisition in postcolonial or immigration settings - the same contexts of interest as for the World Englishes paradigm. However, as discussed in section 3.3.2, Norwegians do not correspond to this postcolonial/immigrant classification of ESL speaker. Furthermore, for much SLA research on language learning and identity, the main concern is with how the learner's identity develops (or refrains from developing) in line with the appropriation of another language, for instance how the learner can develop an imagined identity which will encourage learning the target language: "learners can, but sometimes cannot, appropriate more desirable identities with respect to the target language community" (Norton \& Toohey, 2011: 414). In this view, the learner seems to have status of an 'other', someone whose goal is to take on another's language and access another's community, not to create meaning with language. It assumes a pre-established standard and correct target, something which I have attempted to avoid in this research. However, although this perspective of learner as 'other' seems to prevail in SLA research, it is not exclusive. SLA scholar Claire Kramsch (2006, 2009), for instance, emphasises that L2 speakers have different associations to language forms than L1 speakers, and assign new meanings to these forms. Instead of seeing language as a means to an end, for reaching a communicative aim or for blending in with a target group, Kramsch is concerned with "the personal disturbance and realignment experienced by the language user" (Kramsch, 2006: 101) when using a foreign symbolic system. According to Kramsch, the L2 offers speakers imagined subjectivities which do not have to imply appropriating the communities and identities of someone else.

Nonetheless, the object of investigation for Kramsch, as in much SLA research on identity, is largely the thoughts and feelings of the language user, and for this reason, a 
preferred methodology for the investigation of identity is personal narratives, or a combination of narratives, observation, ethnography, interviews, and other methods which attempt to access an individual's thoughts, desires and commitments (Block, 2007; Norton \& Toohey, 2011). It seems as though SLA scholars do not to the same extent as sociolinguists go through language to access identity, that the object of investigation is language practice. This research project investigates the socially meaningful use of English as practiced by Norwegian adolescents in an ELT context, not their thoughts and commitments related to learning English (although their thoughts on speaking English is accessed in the research process). Therefore, it applies sociolinguistic methods to do so, and the most appropriate theoretical approach is thus based on sociolinguistic perspectives. However, the educational concern in SLA research on language and identity is very central to this thesis. SLA research on identity shows that learning is enhanced when the teacher engages the learners' identities (Menard-Warwick, 2005). SLA scholars therefore stress the importance of educators taking learner identity and social context into account when developing curricula and instructional design:

the issue of instructional design must always be seen as relative to the needs, goals, and indeed identities of the learners. A number of studies point not so much to 'poor instruction' as to incongruence between the way learners see themselves and the identities they are asked to assume during learning events. (Menard-Warwick, 2005: 266)

This normative application of research is relevant for this thesis, with its interdisciplinary nature and a foot in both sociolinguistics and language education. 


\section{METHODOLOGY}

\subsection{A pragmatic approach: mixed methods}

This study is an exploratory investigation which uses both quantitative and qualitative methods and analyses. The project is a mixed-model study (as defined in e.g. Johnson \& Onwuegbuzie, 2004; Tashakkori \& Teddlie, 1998), which pragmatically uses the methods necessary to meet its research objectives. In addition, several practical concerns placed certain restrictions on the research design: within the limited scope of one $\mathrm{PhD}$ study, the sample was geographically restricted to the Oslo area. However, in an attempt to reflect the diversity of the Oslo student population, students from schools located in different sociogeographical areas in Oslo participated. In order to access some sort of meaningful practice, it was preferred that the adolescents knew each other, at least to a certain extent, and that they shared some sort of community through a shared repertoire (cf. Eckert \& McConnell-Ginet, 1992; Wenger, 1998). Therefore, entire school classes were asked to participate in the study. Four school classes with a total of 97 students participated. See section 5.2 below for details about the sample.

97 students is a large enough sample to make claims (see section 5.5.2 below for a discussion on validity and generalizability), but small enough to collect extensive data about attitudes, language choices and language use. In order to collect such complex data, a mixed methodology was used. The purpose of a mixed methods design is twofold: on the one hand there is triangulation, i.e. seeking convergence of results by using different methods. The idea is that using different methods will show the research phenomenon from different angles and that this will give a more complete and true picture of the practices under consideration. However, social reality is complex, and in cultural research, the picture will in fact look different from different perspectives (Silverman, 2006). Using multiple methods can add the complexity, richness and depth appropriate to describe social practices. In addition to triangulation, therefore, the purpose of using mixed methods is complementarity and expansion. The research design in the present study consists of methods which are appropriate for the different parts of the study; L2 pronunciation, attitudes and reported choices - as well as for the study as a whole; social meaning in the L2 of this specific context. Table 1 below gives an overview of the methods and analyses used in the study. 
Table 1. An overview of the methods and analyses used in the study

\begin{tabular}{|c|c|c|c|}
\hline \multicolumn{2}{|c|}{ Quantitative data } & \multicolumn{2}{|c|}{ Qualitative data } \\
\hline Method & Analysis & Method & Analysis \\
\hline $\begin{array}{l}\text { Recordings of } \\
\text { speech in two } \\
\text { situations }\end{array}$ & $\begin{array}{l}\text { - auditory analysis } \\
\text { - production across } \\
\text { situations (paired samples t- } \\
\text { test) } \\
\text { - effects of reported accent } \\
\text { aim, school, gender, home } \\
\text { language (ANOVA, t-tests) }\end{array}$ & $\begin{array}{l}\text { Quest- } \\
\text { ionnaire }\end{array}$ & $\begin{array}{l}\text { thematic analysis of } \\
\text { accent aim reasons } \\
\text { discussion of } \\
\text { language choices }\end{array}$ \\
\hline $\begin{array}{l}\text { Verbal-/matched- } \\
\text { guise test }\end{array}$ & $\begin{array}{l}\text { - principal components } \\
\text { analysis } \\
\text { - comparison across } \\
\text { evaluational dimensions and } \\
\text { gender groups } \\
\text { - effects of reported accent } \\
\text { aim, school, gender, home } \\
\text { language (ANOVA, t-tests) }\end{array}$ & $\begin{array}{l}\text { Inter- } \\
\text { views }\end{array}$ & $\begin{array}{l}\text { discussion of } \\
\text { language choices in } \\
\text { social context }\end{array}$ \\
\hline Questionnaire & $\begin{array}{l}\text { - demographic information } \\
\text { - reported accent aims }\end{array}$ & & \\
\hline
\end{tabular}

The next subsections will present the different elements of the research design; the sample, the different stages of data collection, and the data handling processes. The final subsection discusses research credibility issues such as ethical concerns, generalizability and validity.

\subsection{Sample}

This thesis reports results from two data sets: Data set 1 is comprised of 23 participants from one Oslo school, collected in 2006 and reported on in Article 1. Data set 2 was collected in 2009/2010 and includes 74 participants from three different schools in Oslo. Of these 74 participants, 70 was present for the verbal-guise test and questionnaire, which constitute the material for Article 2, and 70 agreed to be recorded and are analysed for Article 3 (the four absentees are not the same across Articles 2 and 3, which explains the small difference in the accent aim results between the two articles). The participants and the methods applied in the two data sets are very similar and will be presented jointly; differences between them are reported when relevant. An overview of the material from Data sets 1 and 2 used in the three articles is given in Table 2. 
Table 2. Overview of the data used from the two data sets in the three articles

\begin{tabular}{|c|c|c|}
\hline $\begin{array}{l}\text { Article 1: } \\
\text { Constructing identity with L2: } \\
\text { Pronunciation and attitudes } \\
\text { among Norwegian learners of } \\
\text { English }\end{array}$ & $\begin{array}{l}\text { Article 2: } \\
\text { Learner attitudes and L2 } \\
\text { choices in Norway }\end{array}$ & $\begin{array}{l}\text { Article 3: } \\
\text { Being 'neutral'? English } \\
\text { pronunciation among } \\
\text { Norwegian learners }\end{array}$ \\
\hline $\begin{array}{l}\text { Data set } 1(\mathbf{N}=\mathbf{2 3}) \text { : } \\
\text { Recordings of word list } \\
\text { readings and conversational } \\
\text { dyads } \\
\text { Matched-guise test: } 2 \text { speakers, } \\
4 \text { guises, GenAm/SSBE } \\
\text { Questionnaire } \\
2 \text { focus-group interviews }\end{array}$ & $\begin{array}{l}\text { Data set } 2(\mathbf{N}=\mathbf{7 0}) \text { : } \\
\text { Verbal-guise test: } 9 \text { speakers, } \\
11 \text { guises, } \\
\text { GenAm/SSBE/ScE/Leeds } \\
\text { Identification test } \\
\text { Questionnaire } \\
3 \text { focus-group interviews }\end{array}$ & $\begin{array}{l}\text { Data set } 2(\mathbf{N}=\mathbf{7 0}) \text { : } \\
\text { Recordings of word list } \\
\text { readings and } \\
\text { conversational dyads } \\
\text { Questionnaire } \\
3 \text { focus-group interviews }\end{array}$ \\
\hline
\end{tabular}

Data set 1 was collected in a city-centre school, while the three schools in Data set 2 are situated in the east, west and centre of Oslo, respectively. The east and west areas of Oslo are traditionally separated economically and socially, as well as geographically by the Akerselva river. While the west is associated with higher economic and cultural capital (cf. Bourdieu, 1977), the east is more dominated by working-class neighbourhoods and socialistic political orientations (Mjaaland, 2011; Øia, 2007). Furthermore, the east has a higher concentration of immigrants and is considered an area with multicultural and multiethnic settings (Opsahl, 2009; Oslo Kommune, 2012). The city centre schools are urbanely located, have strong cultural profiles, and have the highest achievement level requirements for admissions, making them popular schools (Education Authority, 2012). The schools' sociogeographical locations are reflected in the demographic overview in Table 3 below; there are considerably more students with another home language instead of or in addition to Norwegian in the east side school (School C), less in the city centre school (School B), and few in the west side school (School A). All the schools had relatively high admission standards and consequently students would have had relatively high achievement levels in lower secondary school. Furthermore, most of the participants reported that they intended to go on to higher education. The students who constitute the sample are thus assumed to be relatively academically oriented. 
Table 3. Overview of participants' gender and home language in the four schools of Data sets 1 and 2. Participants in Data set 1 were not asked about home language. Information about home language is missing for three participants in Data set 2.

\begin{tabular}{|c|c|c|c|c|}
\hline \multirow[b]{2}{*}{ Total } & \multirow{2}{*}{\begin{tabular}{|c|} 
Data set 1 \\
School $\mathbf{S}$
\end{tabular}} & \multicolumn{3}{|c|}{ Data set 2} \\
\hline & & School A & School B & School C \\
\hline
\end{tabular}

\begin{tabular}{lccccc} 
Male & 39 & 6 & 16 & 9 & 8 \\
Female & 58 & 17 & 6 & 19 & 16 \\
& & & & & 5 \\
Norwegian only L1 & 37 & - & 15 & 17 & 17 \\
Other/additional L1 & 34 & - & 6 & 11 & \\
\hline
\end{tabular}

There were initially 28 students in the school class in Data set 1, but five were omitted from the study because they had not learned English in Norwegian schools: two exchange students, one student who had recently immigrated to Norway, and two participants who had resided and acquired a variety of English in native environments. Following my own increased awareness of the heterogeneous student community in Oslo, I decided not to omit any students from Data set 2, in order to best reflect the ELT community. In Data set 2, half of the participants reported to have another home language in addition to or instead of Norwegian, but $90 \%$ reported to have attended Norwegian school from year 1, and so most of the participants would have learnt English in the Norwegian school system and in the Norwegian society. The participants were recorded in Norwegian as well as in English, and although some had detectable influence from other languages than Norwegian in their pronunciation, they were all fluent Norwegian speakers. Furthermore, all participants in both data sets used more or less the same Norwegian spoken variety, namely Urban East Norwegian (Kristoffersen, 2000), with some traces of other L1s and multiethnolectic Norwegian (Svendsen \& Røyneland, 2008) for Data set 2 participants.

The participants were 17 years old and in their second year of upper secondary school when the data was collected. They had chosen English as a subject after several previous years (seven years for Data set 1, nine years for Data set 2) of English teaching in school, and could thus be considered motivated and proficient learners of English. This purposive sampling of students with an interest in the school subject English might limit the transference of results to learners who are precisely that: motivated and proficient. However, as a researcher I depended on the participants' willingness to be recorded while speaking English, as well as a certain level of second language awareness in order to access information about language attitudes and choices. The sample was chosen because I assumed they could provide 
more information about the research topic than younger learners in a mandatory English class. Motivated and proficient participants are thus both a strength and a limitation for the study.

The school classes were contacted through their respective English teachers, who in turn were recommended by an administrative contact within each school. The teachers were given limited information about the project beforehand, so that they would not alter any teaching practices or talk to their students about the research topic prior to the data collection. I wanted to avoid too much focus on language as object of investigation so that the participants would not drastically alter their pronunciation. However, attempting to avoid focus on speech would have been futile in the present study, since the students were asked to use an L2 and introductions were made through their English teacher. Instead, I attempted to avoid attention paid to pronunciation specifically, by being explicit about the English language focus of the research, but not mentioning pronunciation explicitly in the oral and written information presented to the students. Nevertheless, to avoid language accommodation or any general pleasing factor towards me as researcher, it was imperative that I did not speak English during the data collection. This decision was justified when I later returned to the schools for a presentation of the project (cf. section 5.5.1), which I gave in English: my L2 accent is strongly influenced by Standard Southern British English, and when I a few minutes into the presentation asked for their impression of me based on my English pronunciation, one student replied (in an L2 accent strongly influenced by American English) "that you think you're better than us".

\subsection{Data collection}

In the following I present some of the issues related to collecting the data, while the next section (5.4) presents issues related to handling the data. This information is to be regarded only as a supplement to the methodology sections in the three articles. Most of the differences between Data set 1 and Data set 2 are a result of a learning experience from the first set. The methods for Data set 1 were constructed following a pilot study using six Norwegians in their early twenties. The methods of Data set 2 were adjusted following the collection of Data set 1 and an additional pilot study with four Norwegians of the same age and in the same ELT environment as the participants in the study presented here.

\subsubsection{Recordings}

The participants were recorded in two speech situations; while reading a word list and in conversations with a class mate of their choice. The idea with a word list reading is that 
speakers, when not having to focus on what they are going to say, concentrate more on how they are going to say it. I was present at both the word list reading and the conversations, but there was still a difference in the formality level of the two situations: I was alone with the participant during the word list reading, but prior to the conversations they were informed that I was not to be part these. The participants were given a list of topics as a conversation starter. This proved very useful, which means there might have been some discomfort by being prompted to speak in the L2 while being recorded (although less so for the girls, who were overall much better at talking for ten minutes about anything). However, all participants had ten-minute conversations in English, with an additional two minutes in Norwegian (see section 3.3.2 for more about the 'naturalness' of speaking English in ELT contexts). The teachers were recorded while they were teaching, on my first visit to the class. The word lists as presented to the participants in Data sets 1 and 2 are presented in Articles 1 (p. 129) and 3 (p. 176), respectively.

\subsubsection{The matched/verbal-guise test}

The participants in both data sets listened to recordings of native speakers of English and evaluated them on semantically labelled scales in an evaluation form. In Data set 1 the stimulus included two speakers producing a total of four voices in Standard Southern British English (SSBE) and General American (GenAm), while in Data set 2 this was expanded to nine speakers producing a total of 11 voices, with Scottish and Leeds English varieties in addition to SSBE and GenAm. In both cases the evaluation test was administered after the recordings, so that the stimulus voices would not affect the participants' L2 production.

The rationale of a speaker evaluation test is an acknowledgement of the difficulty of turning language attitudes into something measurable, and it is an attempt to elicit people's private attitudes while avoiding social desirability bias (Garrett, 2010). The matched-guise technique (MGT) and its derivatives, such as the verbal-guise technique (VGT), is an indirect evaluation method meant to evoke attitudes towards language varieties and the social groups who use them. In a matched-guise test, recordings of two or more languages or accents produced by a single speaker is evaluated by listeners who are under the impression that they are listening to different speakers, thus allowing for evaluation of varieties irrespective of individual voice attributes. Results from matched-guise tests show that the listener's personality judgements change when the speaker modifies his style of speech. The matchedguise technique was used in Data set 1, and in order to ensure accent and mimicking authenticity, the stimulus was limited to two speakers who produced word lists in both SSBE 
and GenAm accents. The recorded word lists were checked by native speakers of both varieties, and any items that did not sound authentic were removed from all recordings. The final word list in the stimulus was the same as the one read by the participants (see appendix in Article 1, p. 129).

In Data set 2 the stimulus was expanded to nine speakers, both female and male, in an attempt to increase the validity of the test. In order to moderate stimulus formality, reading style was chosen instead of word lists; the speakers read the 114-word text The North Wind and the Sun (Appendix 2). Reading style was chosen (as in e.g. Dalton-Puffer, Kaltenboeck, \& Smit, 1997; Ladegaard, 1998) instead of spontaneous speech on a controlled topic (as in e.g. Maegaard, 2005) in an attempt to use a 'factually neutral' text and avoid personal voice characteristics (see Garrett [2010: 59] for a methodological discussion on stimulus text). However, this seemed to enhance the problem of accent and mimicking authenticity, and following a series of authentication assessments, several voices were removed, leaving only two recordings produced with an accent which was not the speakers' own. Two speakers produced two voices each: one SSBE voice and one GenAm voice were produced by a male speaker who was born and raised in the USA by an American mother and a Southern British father, and who had worked as a linguist in both the USA and England. One SSBE voice and one Scottish English voice were produced by a female speaker who was born and raised in Scotland, but where SSBE had been spoken in the family. The inclusion of these matchedguises preserves some of the original motivation for an MGT - to investigate whether accents are evaluated differently even though individual voice attributes are the same.

Apart from these two actual matched-guises, the final test for Data set 2 is a derivative of the matched-guise technique, namely the verbal-guise technique (VGT), which has separate speakers for each variety (Garrett, 2010). The pre-assessment of native-like authenticity favours the use of verbal-guises instead of matched-guises; using separate speakers for each variety gives more accurate representations of accents. However, this increases the possibility of listener evaluations being influenced by individual speaker attributes other than accent. Therefore, the two matched-guise voices were kept in the stimulus, resulting in a modified verbal-guise test. The results of the test presented in Article 2 supports the inclusion of these voices; for instance, the female speaker who produced two voices elicited significantly higher scores when using an SSBE accent than when reading with a Scottish English accent. The results for this matched-guise speaker strengthen the overall results which show that SSBE speakers are rated more favourably than Scottish English speakers. 
The test evaluation form is given as an appendix to Article 2 (p. 153). The instructions were similar for both data sets (but see Article 1, p. 115, for the qualities evaluated in Data set 1), and are described in Articles 1 and 2.

\subsubsection{The identification test}

The purpose of the identification test was twofold: firstly, it was an attempt to address the 'perception problem' (Garrett, 2010) of the matched-guise technique and its derivatives; whether participants geographically identify the stimulus accent as intended by the methodology. Secondly, the test was intended to explore which English varieties are most widely identified among the participants. The identification test was included in Data set 2 only, following the expansion from Data set 1 of stimulus pronunciation beyond the American English/British English dichotomy (see Appendix 3 for the test as presented to the participants). The identification test followed directly after the evaluation test, and the test appeared on the last page of the evaluation form.

The test proved difficult to design without imposing predetermined delimitations of English accents. Pilot study participants were given test versions with both an open-ended design and a multiple-choice design. The open-ended design turned out to be complicated for the participants; they were unsure about the expected detail of their answer - nation, state or city, and wrote lengthy deductions instead of simply the name of an English-speaking community. These sorts of answers would of course produce excellent data - but not for the purposes of this study, where the identification test was only one of a composite of methods, intended to give an overview of 70 participants' ability to correctly identify the origin of native speakers of English. Therefore, a multiple-choice design was chosen for the identification test, even though this meant presenting the participants with labels of Englishspeaking communities. Including the labels 'Great Britain' and 'USA' would limit the choices to only these two, and would not be able to test identification of Scottish English or Leeds English speakers. Therefore, participants were presented with the choices 'England', 'USA' and 'Other country', and asked to specify this last option. The participants were informed orally and in written instructions on the test form that not all English-speaking countries were represented, and that the number of people from different countries might not be evenly distributed. Prior to the identification test, the participants' teachers seized the opportunity to repeat with their students the notions of UK, Great Britain and England (of which knowledge is syllabus), which also ensured concept agreement. 
This design seemed to result in participants checking the 'Other country' box for the Scottish English speakers and the Leeds English speaker, because these in some way differed from the rest. It could be argued that the design therefore misled the participants into erroneous identification of the Leeds English speaker. However, the test gave an overall impression of the participants' familiarity with English accents; mostly correct identification of the 'standard' SSBE and GenAm accents, but relative uncertainty related to the 'nonstandard' Leeds English and Scottish English accents. Participants identified the SSBE and GenAm stimulus as intended by the methodology, and the Leeds English and Scottish English stimulus as 'something else'.

\subsubsection{Questionnaire}

Following the evaluation test, a questionnaire was administered. The questionnaire included both multiple-choice and open-ended questions about participants' experience with the English language, media use, interests, parents' education, home language, future plans, school results and language choices. As a sign of goodwill to the participants' English teachers, who were more inclined to let me take students out of English class if the reason was about English and in English, the questionnaire was given in English.

\subsubsection{The interviews}

A total of 12 participants across both data sets were interviewed in pairs or groups of three, generating five interviews. Interviews were semi-structured and were held in Norwegian for the participants' ease; the purpose was not to document language production, but to explore young L2 speakers' language attitudes and choices, their social reality and practices, and their thoughts about English in and out of school. The interviewees were chosen because they represented the three most common accent aims; American English, British English and Neutral English, and because they emerged as thoughtful and communicative learners in the questionnaires and during the recordings. For Data set 2, choice of interviewees and interview guide were specifically aimed towards what the questionnaire might have missed, namely reasoning for a Neutral accent aim. The interview sampling in this study is thus purposive and relevant to the theoretically defined universe in which the research is based, in line with sampling guidelines for qualitative researchers (Silverman, 2006). Teachers were also interviewed following the data collection among the students, but these interviews were mainly used as ethnographic information in my account of the Norwegian ELT environment. 


\subsection{Handling the data}

\subsubsection{Production data}

The recordings of the participants' conversations were transcribed verbatim by two assistants using the free downloadable transcription programme Transcriber. I proof-read and if necessary edited all transcriptions. The sound files and transcriptions were then loaded into a password-protected searchable internet corpus in cooperation with The Text Laboratory at the Department of Linguistics and Scandinavian Studies at the University of Oslo. The corpus proved helpful because it allowed for the coding annotations of phonological variables to be saved online. However, it was in addition necessary to play sound files using speech analysis software in order to be able to listen repeatedly to a word or part of a word. The programmes Praat and CoolEdit were used for this purpose.

From Data set 1 , the realisations of four phonological variables - Non-prevocalic $/ r$, Intervocalic /t/, GOAT and LOT - were analysed, amounting to a total of 3488 tokens. The analysis of the production data in Data set 1, presented in Article 1, categorised the participants' realisations as either 'American English' or 'British English'. In Article 3, a joint paper with Caroline Piercy, we wanted to give a more descriptive account of the L2 production. Therefore, we not only added three variables in addition to those included in Data set 1 , namely Post-coronal /j/, Voiceless th and BATH, amounting to a total of 7376 tokens, we were also determined to avoid assigning realisations to pre-determined categories of native forms. The tokens were therefore labelled as linguistic variants such as 'rhotic', 'zero', 'tap' or 'released alveolar plosive'. A random sample of at least $15 \%$ was coded a second time for all variables, as described in Article 3 (p. 162), in order to ensure reliable and accurate measures.

Despite our initial determination to avoid pre-determined categories, most of the variants were in fact described in the same way SSBE and GenAm variants are described, and few variants were coded as 'other'. This does not mean that the realisations were entirely native-like. For instance, many of the participants who realised Non-prevocalic /r/ tokens with rhotic variants produced less rhoticity than what would be expected by native speakers. There was also considerable variation in the 'frontness' of front onsets of GOAT vowels, but the pronunciation was still more front than back. There was a lot of variation in the production data, not only on variable level as discussed in Article 3 and section 6.1 below (see Appendix 8 for individual speaker production), but also on variant level - as can be expected by L2 speakers. However, our aim was to provide a broad overview of the English pronunciation 
used by the participants, and with seven variables and 70 participants, the scope of this study did not allow for detailed descriptions and acoustic measurements of every produced token. Nevertheless, between one native SSBE speaker and one L2 speaker from Norway, we reached consistency and agreement in our annotations, and are satisfied that our analyses reflect the participants' overall pronunciation.

\subsubsection{A note on the use of statistical tests}

The interdisciplinary character of this study, where social meaning is the point of departure, and consequently language and its speakers are interchangeably the object of investigation, brings about a note on the perspective of the data used in statistical tests. The different perspectives from which language use is investigated - language or people - are reflected in the methodology related to the production analysis. More specifically, the perspective for investigation can be reflected in what the unit of analysis is, and therefore what $N$ refers to; whether $\mathrm{N}$ refers to the number of tokens or whether $\mathrm{N}$ refers to the number of participants, i.e. the speakers of the tokens. In an Excel or SPSS spreadsheet, an N=token departure would be characterised by one row per token, while an $\mathrm{N}=$ participant departure would be characterised by one row per participant. The different $\mathrm{N}$ perspectives reflect what you want to say something about - whether you want to say something about language or you want to say something about the people that use it. In this study, I want to say something about both. For both data sets, i.e. in both Article 1 and Article 3, statistical tests have been performed to investigate the effect of reported accent aim on variant use; finding out whether the participants pronounce English the way they say they try to pronounce English. In Article 3, which presents the production data from Data set 2, Figures 1 and 2 show overall variant use and variant use by accent aim, presented with percentages of tokens. However, the statistical tests that accompany these figures, are performed with data organised by an $\mathrm{N}=$ participant perspective; the numbers used in the statistical tests are the percentages of variant realisation per speaker (represented by one row per participant in SPSS).

Compared to Data set 2, Data set 1, presented in Article 1, is smaller; $\mathrm{N}$ is lower for both tokens and participants. Table 4 in Article 1 (p. 117) says something about language; how much of the L2 among AmE aimers is realised as respectively American English and British English, and how much of the language among BrE aimers is realised as respectively American English and British English. The numbers in percentages in Table 4 are quite obvious: although both $\mathrm{AmE}$ aimers and $\mathrm{BrE}$ aimers use high percentages of American English variants, the percentages are much higher for AmE aimers than for BrE aimers. 
Results from a one-way ANOVA were presented in this table to support the obvious differences between the $\mathrm{AmE}$ aimers and $\mathrm{BrE}$ aimers. However, a chi-square test of independence might be a more appropriate means of showing the relationship between reported accent aim and variant use, as it allows for an investigation of the relationship between two categorical variables. When performing a chi-square test of independence with the data in Table 4, the results are much the same as those presented in Article 1; variant use is significantly associated with reported accent aim at the .001 level of confidence for all four phonological variables. $^{2}$

The chi-square is performed on a data set organised by an $\mathrm{N}=$ token perspective, which means that $\mathrm{N}$ is very high. We can investigate the effect of accent aim on production with speakers as unit of analysis instead of tokens, by performing tests on the data organised by participants, and with relative production data which will acknowledge the requirement for continuous dependent variables. After removing the participants who did not aim towards AmE or BrE, $\mathrm{N}$ is $19 .^{3}$ This is a low $\mathrm{N}$ for statistical tests, but worth performing for demonstration purposes: t-tests were performed with the production data from Data set 1 (presented in Article 1), after these were re-organised to percentages of variant realisation per speaker ( $\mathrm{N}=$ participant) as in Article 3 (although in Article 3 we did an ANOVA since there were more than two accent groups). Results from these t-tests support the impression given by the obvious percentages from the $\mathrm{N}=$ token departure in Table 4, Article 1: AmE aimers use significantly more rhotic variants of Non-prevocalic /r/, more tapped variants of Intervocalic /t/, more back-initial vowels for GOAT, and more unrounded LOT vowels than BrE aimers $(p<.05)$, i.e. all variants that are also found in GenAm. See Appendix 4 for the t-test results.

It should be noted that parametric tests, such as the ANOVA and t-test, are dependent on a number of assumptions, including random sampling, independence of observations, and normal distribution (Bryman \& Cramer, 2011; Johnson, 2008). Many of these assumptions for parametric techniques are probably violated in social science research. Kleven (2008), for instance, argues that educational research rarely meet the requirements of probability sampling, considering its interest in particular groups of students. Furthermore, one could imagine that social science data, perhaps especially sociolinguistic data, are often not normally distributed, as people tend to cluster. However, it seems as though, in the social sciences parametric tests are still used to investigate these kinds of data. In this thesis,

\footnotetext{
${ }^{2}$ Non-prevocalic $/ \mathrm{r} /: \chi^{2}(1, \mathrm{~N}=1182)=218.68, \mathrm{p}=.000 ;$ Intervocalic $/ \mathrm{t} /: \chi^{2}(1, \mathrm{~N}=454)=82.73, \mathrm{p}=.000 ;$ GOAT: $\chi^{2}(1, \mathrm{~N}=668)=41.64, \mathrm{p}=.000 ;$ LOT: $\chi^{2}(1, \mathrm{~N}=444)=70.47, \mathrm{p}=.000$.

${ }^{3}$ In both Articles 1 and 3, participants with less popular accent aims were removed from the analysis, since $\mathrm{N}$ must be higher than 5 for each group in order to perform an ANOVA or a t-test.
} 
statistical tests are used alongside graphical representations and numbers in percentages, as well as qualitative data, which combined form the basis from which my claims are presented. Even so, the issue of normal distribution is briefly dealt with here: following Shapiro-Wilk tests of normality which did not find the accent aim groups in either data set to be completely normally distributed, non-parametric tests were performed on both data sets to affirm the relationship between reported accent aim and variant use. Results from a Mann-Whitney test for Data set 1 and a Kruskal-Wallis test for Data set 2 closely align with the results from the parametric tests; these tests show significant effects of reported accent aim on variant use for most phonological variables, as argued in Articles 1 and 3. See Appendix 4 for an overview and comparison of all parametric and non-parametric test results.

From whichever perspective the data is examined, then, the conclusions are the same: American English variants dominate the pronunciation among Norwegian adolescents, but the speakers produce to a certain degree the variants found in their targeted variety of English, which suggests a high level of L2 awareness and competence.

\subsubsection{Evaluation data}

The scores from the verbal-guise test and the identification test were coded by an assistant. I coded a random sample of $10 \%$ a second time, and found only a minute discrepancy of 3/1456 scores. The codings were therefore thought to be reliable and accurate. Both the assistant and I checked the evaluation forms for obvious sabotage responses, such as patterns formed by circling specific scores on the evaluation sheet, but none were found. In cases with any doubts regarding participant intentions, e.g. one score crossed out and another circled, these were coded as missing values.

For Data set 1, presented in Article 1, the qualities of the scales in the matched-guise test were pre-grouped into three dimensions based on previous research in comparable contexts, i.e. contexts where L2 speakers of English evaluated native English accents. These three dimensions were labelled Status AND COMPETENCE, Social ATTRACTIVENESS and LINGUISTIC QUALITY, in line with previous research and the qualities that constituted them. ${ }^{4}$ For Data set 2, presented in Article 2, a principal components analysis (PCA) was performed on the scores given to each individual quality on the evaluation form. The PCA showed that the participants' attitudes patterned into three evaluative dimensions, reflecting those

\footnotetext{
${ }^{4}$ In Article 1, the qualities in the scales are labelled 'dimensions', while the larger categories STATUS AND COMPETENCE, SOCIAL ATTRACTIVENESS and LINGUISTIC QUALITY are labelled simply 'categories'. However, in order to reflect the terminology generally used in the field, the qualities in the scales are in Article 2 and in this EA labelled 'qualities' or 'traits', while the larger categories STATUS AND COMPETENCE, SOCIAL ATTRACTIVENESS and LINGUISTIC QUALITY are more appropriately labelled 'dimensions'.
} 
established by previous language attitude research (cf. Article 2, pp. 132-133) and those that I pre-grouped in Article 1 (based on the same previous research). This indicates consistency across data set results, and is a validation of the attitude methodology. However, a critical examination of the results from the verbal-guise test suggests that individual speaker attributes other than accent could have influenced participant judgement for one of the stimulus voices. This methodological limitation (discussed in Article 2) strongly suggests that data from such a test is best combined with other sources of data. In this study, the results from the quantitative evaluation test are triangulated with data from a questionnaire and focus-group interviews.

\subsubsection{Questionnaire and interviews}

Since I did not know how much and what type of data would be needed to answer my research questions prior to the administration of the methodology, the questionnaire was extensive and generated a vast amount of information, of which most is not used directly in the study. However, the information was not redundant - it constitutes ethnographic information which is useful for me as a researcher to construct the context in which the participants practice language. (Although I could probably, with the remaining data from the questionnaire, write another article, if not an entire thesis, about Norwegian adolescents' relationship to English.) The questionnaires from both data sets are given in their entirety in Appendices 5 and 6.

The questionnaire items most central to this study are the questions about which accent the participants aim towards when they speak English, and why (items 29-30 in Appendix 5 and 28-29 in Appendix 6). This question was developed from Data set 1 to Data set 2, by adding the alternatives 'Neutral' and Norwegian to the original alternatives American, British, Other and I don't care. Choices reported by the participants are in this thesis referred to as 'accent aims'. It seems as though even this array of accent aim alternatives could not aptly reflect all possible answers for the participants - one participant did in fact circle both American and British and wrote "depends" in the margin and "It can be useful to learn both" as answer to the Why-question. Also, the Why-question specifically asked the participants for reasons related to American English and British English accent aims, because an initial focus of the study was attitudes specifically towards these most widely identified accents. As my impression of the English language practices among the adolescents evolved, focus was redirected to the negotiation of linguistic resources and 
particularly the wish to speak 'neutral' English. Participants were therefore selected specifically to explore this further in the interviews.

Participants are in Article 1 referred to as $U S$ aimers and $G B$ aimers, based on their accents aims. However, following an acknowledgement that English not necessarily is unreservedly defined by the nation states in which it (by some) is used (cf. section 3.1), participants are in Articles 2-3, as well as in this EA, referred to as American English (AmE) aimers, British English (BrE) aimers and Neutral aimers.

Despite the fact that the two items about accent aim in the questionnaires might have worked better as open-ended items, answers to these questions have produced rich data on language choices. These answers contribute to showing how participants' English pronunciation correlates with their accent aim, that the participants do in fact evaluate English accents and make explicit pronunciation choices, and that these pronunciation choices are partly based on their accent evaluations and desired self-image.

Participants in the focus-group interviews were representatives from all the main accent aim groups: five BrE aimers, three AmE aimers, three Neutral aimers, and the participant who aimed towards both $\mathrm{AmE}$ and $\mathrm{BrE}$. The interviews tapped into various language experiences and attitudes, but data has been used pragmatically, following the rationale of a mixed methods design (cf. section 5.1). Interview data has been used to support data from the quantitative methods and the questionnaire, giving a more complete picture of L2 practices (triangulation), for instance related to evaluational judgements of native accents of English. It has also been used to add complexity to issues where other, more restricted data failed to provide sufficient material for inferences (expansion), for instance related to social meanings and language choices. Excerpts from the interviews are thus used in the articles and in section 6 below as examples and illustrations of quantitative data, as well as empirical agents of theoretical assumptions, adding depth and meaning to the analysis.

\subsection{Research credibility}

\subsubsection{Ethical considerations}

The study was reported to the Norwegian Social Science Data Services (NSD) ${ }^{5}$, and the material has been handled according to their guidelines (NESH, 2006). The participants gave their informed consent to participation in the study after having received written and oral information about how the recordings and transcripts would be handled. In an attempt to

\footnotetext{
${ }^{5}$ http://www.nsd.uib.no/nsd/english/index.html
} 
avoid too much focus on pronunciation and attitudes, the participants were not told the specific aims and focus of the study; they were informed that the study would investigate how Norwegian adolescents use English and what they think about English. However, I returned to the three schools after all the material had been collected to 'brief' the participants on the specific aims of the study. To further avoid that the participants would alter their linguistic practice for the study, there was no payment of any kind. The participants were taken out of class during lessons designated for individual study.

In a few cases, some stuttering and strained phonation (e.g. high pitch) in the recordings suggests that the participants could be uncomfortable about being recorded while using their L2 (or by being recorded in general). However, they were informed that participation was voluntary and that they were allowed to quit the project at any time without having to give reasons for this. Three participants did in fact choose not to be recorded, but nobody has asked to be removed from the study. All participants were given participant numbers, which linked the contributions to their respective source. The key between participants and their numbers has been kept non-electronically, and separate from the recordings and personal information. When transcribing the recordings, all proper names except public figures or locations were anonymised, in order to keep the risk of identification to a minimum.

\subsubsection{Reliability, validity and generalizability}

The scientific quality of a study's methods is not determined by whether they are quantitative or qualitative, but rather whether they are appropriate to the research purpose (Silverman, 2006). Therefore, the intention of this study was to choose methods on the rationale that they would meet the research objectives, both separately and combined. The resulting research design is a mixed methods study, where the methods combined can answer a broad range of research questions, strengthen and add complexity to the results by triangulation and expansion, and present more complete knowledge which will increase the generalizability of the study (cf. Johnson \& Onwuegbuzie, 2004). Below is a brief discussion of some of the reliability, validity and generalizability issues of this research design.

Reliability refers to "the degree of consistency with which instances are assigned to the same category by different observers or by the same observer on different occasions" (Hammersley, 1992: 67). In the quantitative methods of this study, namely the coding and analysis of the VGT and the production data, reliability was ensured by a second coding of a random sample (cf. section 5.4 above). Central to the reliability of qualitative methods, is the 
transparency of the research process (Silverman, 2006), which I have attempted to obtain in this section on methodology by presenting the rationale for my choices concerning e.g. sample methods and test design, as well as describing the collection and handling of the data. According to Silverman (2006), qualitative researchers can also improve reliability by making clear the theoretical stance from which the interpretations take place. By presenting an explicit theoretical stance through a conceptual and contextual framework, I have attempted to show how particular interpretations are produced and others excluded.

Transparency is also related to the overall validity of the research, which concerns whether the methodology investigates what it is intended to investigate (Silverman, 2006). Kleven (2008) argues that validity depends on the inferences that are drawn from the data, and is therefore mainly about rational argument. Validity, then, concerns the trustworthiness of the inferences reported by the researcher. Central to this study is construct validity, which involves making inferences from observable indicators to non-observable constructs or abstract concepts (Kleven, 2008). I make several such inferences in this study, for instance the inference from evaluation test data combined with participant reports to language attitudes, and the inference from quantitative production data combined with speaker commentary to suggestions about stylistic practice. The largest inference of all is from the sum of all observable indicators in the methodology to the abstract concepts of social meaning and identity. My argumentation for this inference is mainly theoretical; the empirical data are interpreted in light of a framework of theoretical and methodological premises, which are presented in the articles and in more detail in this EA. Construct validity, then, seems to be an issue of theory, where the empirical data test the theory's force of explanation.

Because inferences drawn from the empirical data are relevant for the theoretical assumptions within the field, construct validity is therefore also related to external validity, or generalizability. Generalizability concerns the degree to which the inferences drawn extend to other contexts or to other groups (Kvale \& Brinkmann, 2008). Educational research often has an applied nature, and it is important that the researcher makes external inferences - if not, somebody else will. In this study, I use the inferences drawn on the empirical data to present implications for ELT practices in both secondary and tertiary education, as well as implications for how to consider English as L2 in Norway, and by doing so I am generalising the results beyond the 97 students who participated in it. Generalisation is often associated with statistical generalisation - a requirement within a quantitative research tradition - where a large number of subjects are selected at random, and the sample therefore is representative and generalizable to other subjects and situations. However, qualitative research gives insight 
into local practices. Therefore, there is no reason to try to generalise findings globally, but rather to transfer them to similar and relevant situations. This requires analytical generalisation, which "involves a reasoned judgment about the extent to which the findings of one study can be used as a guide to what might occur in another situation" (Kvale \& Brinkmann, 2008: 262). Analytical generalisation can partly be obtained with rich contextual descriptions of the research project, as in the case of reliability. Furthermore, analytical generalisation can be obtained by demonstrating how the presented inferences and conclusions are based on theoretical assumptions and empirical data, as in the case of construct validity, as well as conclusions from previous and related studies. This is what I have attempted to do in the first five sections of this EA. In the next and final section, I present the main conclusions, implications and contributions of the study as a whole. 


\section{DISCUSSION}

This section presents and discusses the empirical, theoretical and methodological contributions of this thesis. All participant quotes in this section are excerpts from the interviews, and are thus translated from Norwegian. Quotes in the original are given in Appendix 7. ${ }^{6}$ Quotes are presented from interviews in all four schools; $S$ participants are students in Data set 1, while participants $A$ through $C$ are students from Data set 2. An overview of the participants who are quoted here, with their reported accent aim, is given in the text box, in order of appearance.

$\begin{array}{ll}\text { C21 } & \text { Neutral aimer } \\ \text { C02 } & \text { Neutral aimer } \\ \text { S06 } & \text { BrE aimer } \\ \text { B03 } & \text { Neutral aimer } \\ \text { S19 } & \text { BrE aimer } \\ \text { S21 } & \text { AmE aimer } \\ \text { A09 } & \text { BrE/AmE aimer } \\ \text { A10 } & \text { BrE aimer } \\ \text { A06 } & \text { BrE aimer }\end{array}$

\subsection{An L2 continuum}

Article 2 argues that there is a discrepancy between the attitudes elicited by the verbal-guise test and the pronunciation aims reported by the participants in the questionnaire: while the Standard Southern British English accent (SSBE) received evaluational judgements from the participants that suggest status as an ELT standard, only a minority reported this accent as their preferred accent aim. ${ }^{7}$ There seem to be other variables than cognitive judgements that have an impact on L2 choices. Even though speakers of SSBE are judged positively by the Norwegian adolescents, this does not necessarily mean that they wish to behave like speakers of SSBE, as argued in section 4.1. Native accents of English, and perhaps especially SSBE, carry with them social meanings which are transferred to their speakers, and in the case of L2 speakers, perhaps even strengthened: the formality function assigned to SSBE is attributed to its speakers, and in the case of the L2 speakers, this function is related to school and ELT and might signal a student who is trying too hard. GenAm might therefore be a more preferred accent aim, seeing as it is not only more linguistically accessible due to more extensive exposure, but also more socially accessible because it is not associated with formality and school like SSBE. Or, L2 speakers might agree to the positive evaluation of SSBE and judge

\footnotetext{
${ }^{6}$ Appendix 7 presents original quotes and translations of interview extracts used in Articles 1 and 3. Article 2 includes quotes in the original.

${ }^{7}$ A larger percentage of the participants reported British as accent aim in Data set 1 (reported in Article 1) than in Data set 2 (reported in Articles 2 and 3). The limited number of participants in Data set 1 prevents any significant inference to be drawn from this difference between the two data sets: it could just be a coincidence. It could also be due to a slight development in the Norwegian adolescents' attitudes towards English during the four years between the collection of Data sets 1 and 2. Or, it could be a reflection of the methdology, and specifically the restricted alternatives given to the participants in the questionnaire of Data set 1 when they were asked to report their accent aim (cf. section 5.4.4). It is therefore best to assume that the two data sets compliment each other, which is how they are treated in this discussion.
} 
it accordingly in the VGT, but still avoid both this accent and GenAm as accent aim, because they are not right for them - a native accent does not reflect who they are:

C21 if I suddenly should have started speaking British then that would just be weird because I don't live in Great Britain I'm not a Brit and I'm not influenced by British culture, like, at all, so that would, like, change parts of the identity

[...]

I think many of us want to be neutral because I want to, like, be thought of as someone who actually knows the language [...] I don't want to, like, be thought of as an American or a Brit

In the same vein, Article 3 argues that there is a discrepancy between reported accent aims and actual pronunciation. The vast majority of all analysed tokens in both data sets were pronounced with variants also found in GenAm. Although there was a statistically significant correlation between the reported accent aims and the realisation of linguistic variables, which means that the participants to a certain degree used the linguistic forms they aimed towards, the extent of GenAm-influenced pronunciation vastly exceeds what would be expected from the reported accent aims. The discrepancy between reported practice and actual practice suggests that language use is not necessarily always an intentional choice, perhaps particularly in an L2. The participants' L2 practices are most likely affected by other variables than cognitive and affective judgements and intentional target accent, for instance competence and exposure. For instance, some participants reported that they had 'settled' for an American accent because British forms were inaccessible (cf. Article 1). Furthermore, limited competence, for instance limited meta-linguistic knowledge of English pronunciation and/or limited opportunities to rehearse an accent might in part explain why most of the participants used more than one variant per variable (cf. Appendix 8), i.e. why they did not imitate a native accent entirely even though they reported one as accent aim: they might not have been able to. Conversely, it could be that this lack of intra-speaker uniformity across phonological variants was deliberate: even though the participants reported a native accent as target, they might not have wished to unconditionally imitate this accent, in an attempt to avoid trying to be someone else. This was a reason for some of the participants to report a Neutral English accent aim altogether, attempting to blend some of the available resources into an 'undetectable' accent:

C02 I speak, in a way, what I've learnt and what I've picked up, a little here and a little there 
Notwithstanding considerable intra-speaker variation, what many participants have 'picked up', regardless of accent aim, seems to be mostly GenAm resources. A deliberate blend of resources cannot account for the GenAm dominance in L2 pronunciation; Neutral aimers, too, realised the majority of tokens with variants also found in GenAm, in some cases even more so than AmE aimers (cf. Article 3). It is not possible to avoid ascribing the GenAm dominance at least in part to English language media, as I also argued in Article 1. Although sociolinguists traditionally have been reluctant to accept that television has any effect on language behaviour (e.g. Chambers, 1998), scholars argue that mass media offer an abundance of sociolinguistic resources (e.g. Coupland, 2007; Stuart-Smith, 2011). StuartSmith $(2007,2011,2012)$ argues that spoken media might affect speakers' phonology and awareness of varieties and ideologies. She concludes from a review of research on the field that television could be "a possible contributory factor in changes in social behaviour" (Stuart-Smith, 2012: 1077). However, it is assumed that other social factors, such as for instance established semiotic links between linguistic forms and social meanings restrain media influence: "We suspect that the overall net influence of television is continually constrained, restricted by existing linguistic patterning and local symbolic functioning of variation as well as by individuals themselves" (Stuart-Smith, 2012: 1085). Conversely, such constraints might not be as strong in an $L 2$, where semiotic functions might be less rigorously linked to linguistic forms (cf. Article 2). The results in the present study strongly suggest that television is not only 'a possible contributory factor' in the development of L2 behaviour, but a major agent of English language exposure and a significant source of linguistic resources influencing learners' pronunciation. Future research could explore the English-speaking styles offered by television in L2 environments, and the extent to which learners identify with these.

In effect, the participants' L2 practices amount to a reflection of their life worlds; the linguistic and social accessibility of linguistic resources, their cognitive and affective judgements of the linguistic resources available, and the negotiation of these resources and their meanings in a particular context with a particular audience. Overall, the results in this study form a continuum of attitudes - choices - behaviour, as proposed in Article 2: on one end of the continuum, the participants' responses to practice - the attitudes elicited from the evaluation tests - ranked SSBE over all other accents for prestige. Their reported practice the accent aims given in the questionnaire - showed that desired targets were more uniformly distributed between the two most widely identified native accents, with an additional group of participants reporting a wish to not aim towards any native accent, but rather 'Neutral English'. On the other end of the continuum is the actual practice - the realisation of 
phonological variables - which an auditory analysis showed to be dominated by GenAminfluenced features. The result continuum from the three articles of this thesis is thus also a continuum of language practices, and a continuum of the methods used to explore them, as shown in Figure 4.

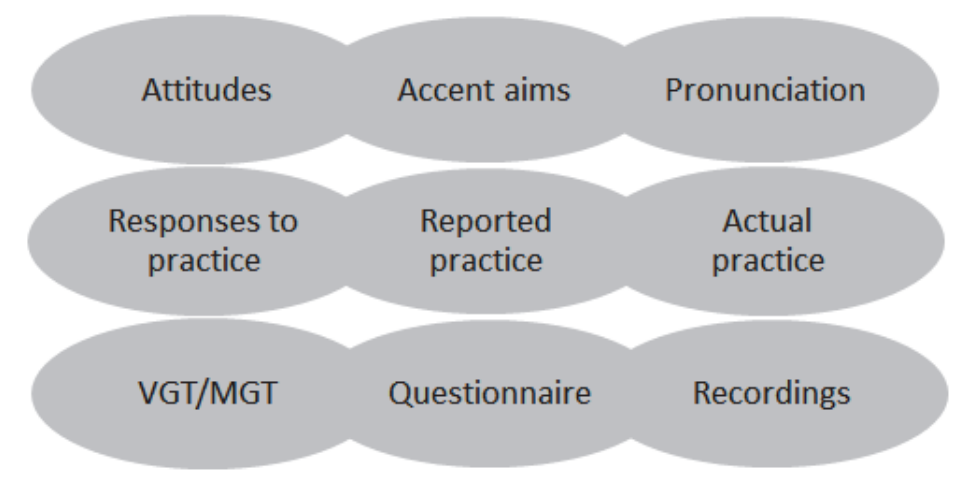

Figure 2. A continuum of results and methodologies

The continuum of language practices in Figure 2 shows another relationship between level of consciousness related to attitudes and language behaviour than traditionally found in language attitude research related to the $L 1$ (cf. section 4.1.1). Language behaviour in this study aligns more closely to the participants' reported choices than the judgements elicited with verbal-guise methodology. This suggests that the relationship between attitudes and behaviour in an L2 differs from that in the L1, where speakers' behaviour more often mirror their 'unaware' judgements of language than the attitudes they say they have (e.g. Garrett, 2010; Kristiansen, 2011). Although there was a certain level of awareness among the participants in this study that language was in fact the object of investigation, the proximate relationship between actual practice and reported practice, as opposed to responses to practice, encourages further investigation into the relationship between 'aware'/'unaware' attitudes and language behaviour in an $L 2$.

The discussions related to the main objective of this thesis - the social meanings of the L2 - arise from the combination of methods and pertaining results in Figure 2. The combination of qualitative and quantitative approaches enhances the validity of the results, as the different data sources and analyses both support and add complexity to the findings. The qualitative data from the questionnaire and interviews about meanings associated with English accents support the results from the quantitative evaluation test: SSBE is considered a prestigious standard, associated with school and formality. But the qualitative data also add levels to the results: SSBE is a marked accent, and thus avoided as target. The markedness of 
SSBE finds resonance in the infrequency of features from this accent in the quantitative data from the auditory analysis: participants will refrain from using an accent that is marked, but the evasion of an accent will also enhance its markedness. In the interview, participants express a desire to use an unmarked accent, which does not carry with it the cultural baggage of another's nationality and history. In the quantitative analysis of the production data, this desire could be reflected in considerable intra-speaker variation. Combined, the quantitative and qualitative data from the three articles tap into the social meanings related to the ways in which Norwegian adolescents use English.

\subsection{A local English - an English identity?}

The results presented in the articles of this thesis suggest that Norwegian adolescents are choosing linguistic resources from available native varieties of English, and assigning new meanings to linguistic forms as they are combined in new ways in a local context. As argued in section 4.2, the negotiation of meaning encompasses both macro-level classifications and local cultural positions. For instance, it seems to be possible for Norwegian L2 speakers to both project qualities associated with entire native varieties, such as Southern Standard British English, and to renegotiate the meanings associated with this accent by combining variants from this accent with variants from other accents. In Article 1, one of the participants negotiates the meaning of the SSBE-like accent she has appropriated into qualities she would like her language to reflect (emphasis added):

S06 [British English] is perceived as more posh [...] more upper class [...] to speak British one must have a certain attitude that can be interpreted as superior [...] but if that means superior as in educated, I don't mind

This participant was one of very few who realised more than $90 \%$ of tokens with variants also found in SSBE. Article 3, which takes a closer look at production, shows that intra-speaker variation is more the rule than the exception, and that the speakers who do in fact use SSBE variants, blend these with variants also found in GenAm, as well as with varying degree of L1 influence. In this way, new meaning is negotiated at a more local level; a bricolage of linguistic forms that in combination index a (for them) unmarked L2:

B03 a cleaner form of English, that there isn't anything dialect-distinctive about it [...] you sort of have to find that thing in between

Although this bricolage is a local stylistic move, it draws resources from an indexical field (cf. section 4.2.3) which is linked to broader structures of politics, culture and economy, which 
both emerge from and constrain the local linguistic practices. Part of this indexical field is also $L 1$ sociolinguistics: in a society with relatively low levels of formality and weak standard ideology (cf. section 3.3.3), speakers are accustomed to using the linguistic forms they are comfortable with. If speakers are not used to language having a standard in their L1, they might not aspire to acquire one in their L2 either. The general sociolinguistic climate of Norway might thus facilitate local uses of the L2.

\subsection{Meaning in L2}

The meanings of the locally constructed styles are socially recognisable to peers, because the peer community share attitudes towards English accents. The L2 resources only index certain meanings because of the backdrop of norms and attitudes widely shared by members in the local culture. Because members of the ELT community practice language against a shared backdrop of ideologies, qualities which are initially associated with established accents of English are assigned to its L2 speakers:

S19 In our class there are many people who take school very seriously, and these people speak British

S21 I think you are perceived as [...] a clever pupil if you speak British

The performance of meanings with language, enabled by a shared cultural backdrop, is not a novel finding. It is demonstrated in research on the negotiation of meaning using L1 linguistic resources (e.g. Bucholtz, 1998; Eckert, 2000; Llamas, 2006; Moore, 2010; Mæhlum, 1992; Podesva, 2007; Røyneland, 2005), as well as in investigations into bilingual speakers' negotiations of ethnicity (e.g. Alim, 2004; Cheshire, Kerswill, Fox, \& Torgersen, 2011; Opsahl, 2009; Rampton, 2005; Stuart-Smith, Timmins, \& Alam, 2011) and non-native speakers' use of English features for pragmatic purposes or to position themselves related to local communities (e.g. Drummond, 2012; Jenkins, 2006b; Mauranen \& Ranta, 2009; Sharma, 2005, 2011). However, in most of this research, speakers use language in meaningful ways, enabled by a shared backdrop of norms and attitudes, to create relations with other participants in the interaction. Interestingly, because of the particular context of Norwegian ELT, speakers make L2 choices based on the backdrop of norms and attitudes which they share with other speakers who are present during the production of language, but who are not necessarily an active part of the language interaction: as argued in section 3.3, Norwegian adolescents in the ELT environment do not need English for communication. They all speak Norwegian and will use Norwegian if not prompted to do otherwise. Although the production 
data in this study is taken from recordings of communicative interactions between peers (because I prompted them to have conversations in English), the L2 pronunciation they use in these interactions, and their reports of desired L2 pronunciations and reasons for these, derive from L2 choices they have made more due to social meaning and style, than due to demands from an interaction: in the ELT classroom, the individual speaker uses English in presentations with the characteristics of a monologue, in dialogues with the teacher, and in dialogue with peers (the latter only if prompted and monitored by the teacher). All the members of the classroom community are proficient in Norwegian, in almost all cases more proficient than in English. ${ }^{8}$ The linguistic choices made by an individual in a particular ELT context are probably, although possibly limited by accessibility and/or competence, a negotiation between desired qualities and meanings based on the backdrop of norms and attitudes shared with peers on the one hand, and desired qualities and meanings based on the predicted expectations of the teacher on the other hand, with whom the shared backdrop of norms and attitudes might be more fuzzy (see section 6.4 below for further discussions related to education). Even though Norwegian adolescents in the ELT context do not need English to communicate among themselves, English still has communicative functions; L2 practices can communicate who you are and what you want. This inference strengthens the significance given to the social aspects of L2 in this thesis: English is not a foreign language to the Norwegian adolescents in this study; English forms are part of a linguistic repertoire, from which resources can be exploited to negotiate meaning.

The social meaning of language, then, is a point of departure rather than an add-on in the investigation of language use. The priority of social meaning takes us to the social group in question, and their contexts, conditions and concerns. The L2 practices among the Norwegian adolescents - responses to practice, reported practice and actual practice - echo the transitional ELT community in which they are members. In a context where the status of English is hybrid, fluid, in transition from one place to a yet unknown other, speakers' use of English, too, is characterised by hybridity, negotiation and variability. This social sensibility and linguistic aptitude can only mean that speaking English is a social practice. As participants in social practice, Norwegian adolescents, regardless of the ELT context, are not primarily English language learners in a traditional sense; they do not attempt to access the cultures and opportunities of others. L2 use of English in Norway is not an interlanguage or

\footnotetext{
${ }^{8}$ There is, however, an increasing amount of students in Norway who are less proficient in both Norwegian and English, compared to another L1. This argues in favour of monolingual ELT classrooms, avoiding Norwegian for translation, and rather attempting to create an ELF environment (see e.g. Solberg, 2001).
} 
an 'incomplete' learner language; this study has shown that there is something systematic going on in the adolescents' use of English. Their L2 practices are in accordance with descriptions of languages and linguistic phenomena used by sociolinguists in other language contexts. Although this study found a great degree of variability, it is variability used in systematic - and meaningful - ways. The participants in the present study are first and foremost English language speakers (who naturally continue to learn and develop their language, like most speakers), and should probably be treated as such by the educational system.

\subsection{The future is social: educational implications and further research}

What does it mean, then, to treat students more like speakers than learners? The transitional status of English in Norway and the pertaining transitional L2 practices among Norwegian students are also echoed in the global status of English. As English continues to spread globally and be appropriated locally, the diversity and hybridity of English increases (Mufwene, 2010). This view of English (and language in general) as diverse and highly variable can be presented to students, rather than feeding 'inner circle' curricula to 'expanding circle' countries (cf. section 3.1.1). If English is an international language of communication, a global lingua franca, students in countries not intimately linked historically or politically with the US or the UK do not really need to know a lot about the culture and history of these countries (Dürmüller, 2008). Instead, culture and literature material could have, like the English language, a global orientation. The current national curriculum in Norwegian schools do in fact recognise the global character of English (cf. section 3.3), but remnants of a traditional Anglo-core orientation appear as recurring references to 'United States', 'Great Britain', 'American' and 'British'; perhaps these remnants should be filtered out of guiding policy documents.

However, more important than policy documents, are the teachers who interpret them. Teachers of English are responsible for discussing with students the local and global status of English. Teachers cannot educate students for the future language demands of society without being provided with current and relevant knowledge about these demands through their teacher education. The real responsibility, then, is with educators in tertiary education, who are in a position to present current and relevant research on diverse practices of English, like for instance the research presented in this thesis. The knowledge presented here about local practices of English in relation to more global and general developments might facilitate teachers' taking into account students' social realities (or life worlds), which in turn can have 
an impact on students' level of investment/involvement in ELT activities. SLA scholars concerned with identity issues argue that education can give learners access to other communities, other networks, in which English competence and education is available (cf. section 4.2.5). This thesis is also concerned with taking learners' life worlds into account, but instead of offering access to a correct target, to something else, language education should offer learners the possibility to be their desired selves in the target language. This implies that educators must not only, as professed by SLA scholars, take into account learners' identities, but also show learners the range of English identities possible, so that learners can find their L2 style.

Based on the discussions in this thesis, it seems clear that presenting native accents of English as 'correct' and asking Norwegian students to imitate these, is problematic. For some students, this implies not just putting on an accent, but also putting on an identity. To the extent that teachers do pronunciation training at all, this should reflect the local and global diversity of English, with the goal of enhancing intelligibility, not acquiring a native accent. Mutual intelligibility as a first and foremost goal of pronunciation training is also argued by Derwing and Munro in a TESOL Quarterly topic issue on pronunciation, but then mostly for reasons of linguistic accessibility:

Studies of ultimate attainment in general suggest that native-like pronunciation among those who acquire an L2 after early childhood is actually exceedingly rare [...] Indeed, we know of no study documenting a link between pronunciation instruction and the elimination of a foreign accent. (2005: 384)

Although I agree with Derwing and Munro's dismissal of native accent targets, the discussions in this thesis suggest that targeting native accents should not be avoided because it is impossible, but because it is unnecessary. Although linguistic accessibility is also an issue for the participants in the present study, their reasons for dismissing native targets are mainly social.

Derwing and Munro (2005: 379) call for "more research to enhance our knowledge of the nature of foreign accents and their effects on communication", in order to inform practitioners of ELT. Their concern is mainly ESL speakers who have immigrated to a nativeEnglish-speaking country, who, according to Derwing and Munro, must pursue an L2 accent which is intelligible to the native speakers in the host country, unlike lingua franca speakers of English, who can get away with adjusting their speech mostly to other non-native speakers. However, Norwegian adolescents will also need English to communicate with native speakers; the UK and the US are the most popular choices for exchange programmes and 
studies abroad for Norwegian students (Hagesæther, 2012; Ministry of Education and Research, 2012), and are likely destinations for holiday or longer stays. In the ELT context discussed here, however, it seems futile to limit pronunciation guidelines to either intelligibility or preservation of social identity. Such a limitation might also be to underestimate Norwegian speakers of English. Given the intra-speaker variability in the production data, and the social concerns expressed in the speaker commentaries, it is not impossible to imagine that these L2 speakers can adjust their L2 to a variety of audiences. This seems at least to be a desired use of the L2, as is shown below by excerpts from a student interview. The excerpts are from an interview with three students in School A; A06 and A10 who both reported to aim towards a British English accent, and A09 who circled both British and American, writing "depends" in the margin, and then, when asked to give reasons for his accent choice, wrote "It can be useful to learn both". In the interview, when asked about which accent of English they use, the boys in School A argue that their accent might vary:

A09 if you naturally try to speak English, like, without thinking about which manner of speech to use then it's more towards the American. If you're going to sit in class and impress the teacher a little then you should maybe try more towards the English- the British

A09's reasoning seems to confirm the school associations to SSBE argued in the articles and here in the Extended Abstract. When A10 is asked why he aims towards a British English accent, his answer indicates that the formality function of SSBE extends beyond the ELT classroom:

A10 it has something to do with what I think I need it for [...]

$U \quad$ so you're thinking that you would rather have British because you'll use it...?

A10 in a work context

$U \quad$ in a work context. then you would rather have the British?

A10 yes, very much

However, the contextual function of English accents seems not only to concern degree of formality, but also audience and location:

A10 if you're abroad, if you're in one area in England or in the US, then you of course automatically start talking like they do

U what if you're in a place which is not England or the US? Spain...?

$[\ldots]$

A06 then you would have spoken sort of Norwegian English, sort of, not a lot, but then you wouldn't have, you wouldn't put on the Oxford accent if you're in Spain, then you just 
speak [...] then you have to speak in a way so they understand because they're not very good at speaking English, many abroad, so then you have to speak a little slow and sort of get them to understand so then you wouldn't try to speak the way you try to speak in the classroom?

A06 no

A09 no

A10 no, never

$[\ldots]$

A10 and then it's like this, that you try to speak yourself up in class and then it can often happen that you speak yourself a bit down when you're abroad, if you're not in an English-speaking country

U 'up'? what do you mean 'up-down'?

A10 no, well, then nicer, try to speak nicer in class, and then rather actually on purpose speak a bit uglier when you're abroad

$U \quad$ for the sake of intelligibility?

A10 yes

A09 and the perception

A10 and maybe you become sort of stuck-up if you speak very sort of fluent English

U why?

A09 but then it's all this environment again. again it also depends which environment you're in in the foreign country, for example, if you're, like, sitting in, like, a shabby ghetto bar you don't pull out your British accent, I don't think so

$[\ldots]$

A09 and at the same time, on the other hand you might be sitting in a slightly nicer tea party later that day, then you would maybe alter your way of speech a bit, I would think

[laughter] [...]

A10 here it is: why?

A09 because you don't want to get beaten up [laughter] [...]

U but why, ok, so you sound stuck-up, in some environments you don't want to speak British because then you sound stuck-up

A06 that's sort of how it is, it also sort of depends who you're speaking with, or what kind of environment you're in. If you're in sort of a, a bit stuck-up, then it's the British

A09 you simply adjust to the surroundings

A06 yes, that's what you do, really

At this point, A09 is asked if 'adjusting to the surroundings' is what he meant when he circled both British and American, which he confirms.

$U \quad$ is it like this, then, that in an ideal world you should know both?

A09 yes, it's an advantage if you can do it

A06 you don't really need to have, like, real American, but you can, at least if you can do the really British and then you have a sort of 
A09 a little something in between that

A06 a little something in between, too

A09 which isn't so stiff

A06 which you can switch on if you're not, like, in the stiffest of companies

Some learners may want a native-like accent because they plan to study or work in a native-speaking country. However, which native norm should ELT teachers choose to present as target and teach to students? Seidlhofer (2010) argues that if learners learn ELF, i.e. how linguistic properties and norms are co-constructed and established in an ad hoc manner to achieve a communicative goal, they will be able to appropriate the local accent in the nativespeaking country to which they move. This would be a way for ELT to treat English as part of students' linguistic repertoire. It might seem as though teachers and learners want native models as targets (Jenkins, 2007; Tupas, 2010), even though sociolinguistic and applied linguistic research encourages otherwise. It could very well be that this yearning for native models is due to a lack of alternatives, as suggested by Seidlhofer (cf. section 3.2). However, presenting several Englishes to students is an alternative, showing the diverse practices of English as well as the social aspects of language. Awareness might be raised about the existence of different linguistic markets (cf. Bourdieu, 1991), about how the value attributed to language varieties varies between linguistic markets, and that this value is not constant. Meanings of language, which are culturally and historically determined, cannot be taught directly like grammar or vocabulary, but can be interpreted, discussed, modelled and examined. Students can observe and evaluate their own practices and beliefs about language, and be allowed to experiment and act out potential styles (Kramsch, 2009). Familiarity with such linguistic and social registers would encourage pragmatic and social competence, which seems to be what students want to do with English, according to the quote above.

Despite the indications in the data of varied L2 use across situations, this thesis does not present evidence of audience accommodation; the results from production in two different speech situations, i.e. word list reading and conversations with peers, are insufficient for discussions of social variation across speech situations. Further research is needed into L2 production across situations with different interlocutors, taking account of the range of language components, not just phonological variables. In particular, the discussions in the present study call for investigations into the individual's L2 strategies and styles. In addition to investigations into intra-individual variation, there is also a need for further research on 
intra-variant variation in L2 production (cf. section 5.4.1), in order to describe local appropriation of English in more detail.

SLA scholars Derwing and Munro call for research specifically on the intelligibility of foreign accents to native speakers. However, in this ELT context, perhaps attitudinal responses to L2 accents are even more relevant for future research. Although the attitude research in this thesis gives valuable information about the social evaluation of available English accents, the delimitation of test stimulus to native speaker Englishes has shown to be insufficient, as English seems to be negotiated locally. The participants explain the variability in their L2 production with a desire to use a neutral accent of English. Of course, there is no such thing as a neutral accent. Further research is needed into how these local English language practices are perceived by both Norwegians themselves and native speakers of English.

The contributions of this doctoral thesis are methodological, empirical and theoretical. Its main contribution might first and foremost be the (successful) application of sociolinguistic inquiry in an L2 context. With this study, I show that it makes sense to describe and analyse L2 use of English in Norway related to standard norms of English, by finding and distinguishing a set of phonological features used across a group of speakers. By doing so, I have included Norwegian L2 speakers of English in English sociolinguistics. Furthermore, by discussing theories of identity and style in relation to the data in this study, I have also shown that there is reason to study L2 English in Norway further using the stylistic practice approach. Through the application of sociolinguistic inquiry in an ELT context this study has accessed a vast field in the intersection between sociolinguistics and English language education in dire need of investigation. Hopefully, the inferences and discussions presented here will encourage scholars and students to take on the challenge. 


\section{References}

Agha, A. (2003). The social life of cultural value. Language and Communication, 23, 231273.

Ajzen, I., \& Fishbein, M. (1980). Understanding attitudes and predicting social behaviour. Englewood Cliffs, NJ: Prentice Hall.

Alim, H. S. (2004). You know my steez: An ethnographic and sociolinguistic study of styleshifting in a black American speech community. Durham, NC: Duke University Press.

Anderson, B. (1991). Imagined communities: Reflections on the origin and spread of nationalism. London: Verso.

Androutsopoulos, J. K., \& Georgakopoulou, A. (Eds.). (2003). Discourse constructions of youth identities. Amsterdam: John Benjamins.

Auer, P. (2007). Style and social identities: Alternative approaches to linguistic heterogeneity. Berlin: Mouton de Gruyter.

Bakhtin, M. (1981). The dialogic imagination: Four essays (C. Emerson, Trans.). Austin: University of Texas Press.

Bakhtin, M. (1986). Speech genres and other late essays (V. W. McGee, Trans.). Austin, TX: University of Texas Press.

Ball, P. (1983). Stereotypes of Anglo-Saxon and non-Anglo-Saxon accents. Some exploratory Australian studies with the matched-guise technique. Language Sciences, 5, 163-183.

Beck, U. (1999). What is globalization? Cambridge: Polity.

Bex, T. (2008). 'Standard' English, discourse grammars and English language teaching. In M. A. Locher \& J. Strässler (Eds.), Standards and norms in the English language (pp. 221-238). Berlin and New York: Mouton de Gruyter.

Bishop, H., Coupland, N., \& Garrett, P. (2005). Conceptual accent evaluation: Thirty years of accent prejudice in the UK. Acta Linguistica Hafsniensia, 37, 131-154.

Block, D. (2007). Second language identities. London and New York: Continuum.

Block, D. (2010). Globalization and language teaching. In N. Coupland (Ed.), The handbook of language and globalization. Chichester: Wiley-Blackwell.

Bonnet, G. (2004). The assessment of pupils' skills in English in eight European countries 2002. Paris: The European Network of Policy Makers for the Evaluation of Education Systems.

Bourdieu, P. (1977). Outline of a theory of practice (R. Nice, Trans.). Cambridge: Cambridge University Press.

Bourdieu, P. (1991). Language and symbolic power (G. Raymond \& M. Adamson, Trans.). Cambridge: Polity Press.

Bryman, A., \& Cramer, D. (2011). Quantitative data analysis with IBM SPSS 17, 18 and 19: A guide for social scientists. London and New York: Routledge.

Bucholtz, M. (1998). Geek the girl: Language, femininity and female nerds. In N. Warner, J. Ahlers, L. Bilmes, M. Oliver, S. Wertheim \& M. Chen (Eds.), Gender and belief systems: Proceedings of the Fourth Berkeley Women and Language Conference (pp. 119-131). Berkeley: Berkeley Women and Language Group.

Bucholtz, M. (2010). White kids: Language, race, and styles of youth identity. Cambridge: Cambridge University Press.

Bucholtz, M., \& Hall, K. (2005). Identity and interaction: A sociocultural linguistic approach. Discourse Studies, 7(4-5), 585-614.

Butler, J. (1990). Gender trouble: Feminism and the subversion of identity. New York: Routledge. 
Chambers, J. K. (1998). TV makes people sound the same. In L. Bauer \& P. Trudgill (Eds.), Language myths (pp. 123-131). London: Penguin.

Cheshire, J., Kerswill, P., Fox, S., \& Torgersen, E. (2011). Contact, the feature pool and the speech community: The emergence of Multicultural London English. Journal of Sociolinguistics, 15(2), 151-196.

Coupland, N. (2007). Style: Language variation and identity. Cambridge: Cambridge University Press.

Coupland, N. (2009). Dialects, standards and social change. In M. Maegaard, F. Gregersen, P. Quist \& J. N. Jørgensen (Eds.), Language attitudes, standardization and language change (pp. 27-49). Oslo: Novus forlag.

Coupland, N., \& Bishop, H. (2007). Ideologised values for British accents. Journal of Sociolinguistics, 11(1), 74-93.

Cruttenden, A. (2008). Gimson's Pronunciation of English (7th ed.). London: Hodder Education.

Crystal, D. (1997). English as a global language (1st ed.). Cambridge: Cambridge University Press.

Crystal, D. (2003). English as a global language (2nd ed.). Cambridge: Cambridge University Press.

Dalton-Puffer, C., Kaltenboeck, G., \& Smit, U. (1997). Learner attitudes and L2 pronunciation in Austria. World Englishes, 16(1), 115-128.

Derwing, T. M., \& Munro, M. J. (2005). Second language accent and pronunciation teaching: A research-based approach. TESOL Quarterly, 39(3), 379-397.

Drummond, R. (2012). Aspects of identity in a second language: ING variation in the speech of Polish migrants living in Manchester, UK. Language Variation and Change, 24, 107-133.

Dürmüller, U. (2008). Towards a new English as a foreign language curriculum for Continental Europe. In M. A. Locher \& J. Strässler (Eds.), Standards and norms in the English language (pp. 239-253). Berlin and New York: Mouton de Gruyter.

Dörnyei, Z. (2001). Motivational strategies in the language classroom. Cambridge: Cambridge University Press.

Eckert, P. (1989). Jocks and burnouts: Social identity in the high school. New York: Teachers College Press.

Eckert, P. (2000). Linguistic variation as social practice. Oxford: Blackwell.

Eckert, P. (2001). Style and social meaning. In P. Eckert \& J. Rickford (Eds.), Style and sociolinguistic variation (pp. 119-126). New York: Cambridge University Press.

Eckert, P. (2004). The meaning of style. Texas Linguistics Forum, 47, 41-53.

Eckert, P. (2008). Variation and the indexical field. Journal of Sociolinguistics, 12(4), 453476.

Eckert, P. (2012). Three waves of variation study: The emergence of meaning in the study of sociolinguistic variation. Annual Review of Anthropology, 41, 87-100.

Eckert, P., \& McConnell-Ginet, S. (1992). Think practically and look locally: Language and gender as community-based practice. Annual Review of Anthropology, 36, 461-490.

Eckert, P., \& Rickford, J. (Eds.). (2001). Style and sociolinguistic variation. Cambridge: Cambridge University Press.

Education Authority. (2012). Inntak til videregående opplæring [Admission to upper secondary school] Retrieved 24th August, 2012, from http://www.utdanningsetaten.oslo.kommune.no/videregaende/inntak/

Education First. (2011). EF English Proficiency Index. 
Engen, T. O., \& Kulbrandstad, L. A. (2004). Tospråklighet, minoritetsspråk og minoritetsundervisning [Bilingualism, minority languages and minority teaching]. Oslo: Gyldendal.

Erwin, P. (2001). Attitudes and persuasion. Hove: Psychology Press.

Firth, A. (1996). The discursive accomplishment of normality: On 'lingua franca' English and conversation analysis. Journal of Pragmatics, 26(2), 237-259.

Foucault, M. (1980). Power/knowledge: Selected interviews and other writings 1972-1977 (C. Gordon, Trans.). Brighton: Harvester Press.

Foulkes, P. (2006). Phonological variation: A global perspective. In B. Aarts \& A. McMahon (Eds.), The handbook of English linguistics (pp. 625-669). Oxford: Blackwell.

Foulkes, P., \& Docherty, G. J. (2007). Phonological variation in England. In D. Britain (Ed.), Language in the British Isles (pp. 52-74). Cambridge: Cambridge University Press.

Garrett, P. (2010). Attitudes to language. Cambridge: Cambridge University Press.

Garrett, P., Selleck, C., \& Coupland, N. (2011). English in England and Wales: Multiple ideologies. In T. Kristiansen \& N. Coupland (Eds.), Standard languages and language standards in a changing Europe. Oslo: Novus Press.

Giddens, A. (1991). Modernity and self-Identity: Self and society in the late modern age. Cambridge: Polity Press.

Giles, H. (1970). Evaluational reactions to accents. Educational Review(22), 211-227.

Giles, H., Coupland, J., \& Coupland, N. (1991). Contexts of accommodation: Developments in applied sociolinguistics. Cambridge: Cambridge University Press.

Giles, H., \& Coupland, N. (1991). Language: Contexts and consequences. Milton Keynes: Open University Press.

Graddol, D. (1997). The future of English? London: The British Council.

Graddol, D. (2006). English next. London: The British Council.

Graedler, A.-L. (2002). Norwegian. In M. Görlach (Ed.), English in Europe (pp. 57-81). Oxford: Oxford University Press.

Graedler, A.-L., \& Johansson, S. (2002). Rocka, hipt og snacksy: Om engelsk i norsk språk og samfunn [About English in Norwegian language and society]. Kristiansand: Norwegian Academic Press.

Gundem, B. B. (1989). Engelskfaget i folkeskolen. Påvirkning og gjennomslag fra 1870-årene til først på 1970-tallet [The English subject. Influence and support from the 1870s to the beginning of the 1970s]. Oslo: Universitetsforlaget.

Hagesæther, P. V. (2012). Rekordmange studenter reiser ut [Record-high number of students go abroad], Aftenposten. Retrieved from

http://www.aftenposten.no/nyheter/iriks/Rekordmange-studenter-reiser-ut6975851.html

Hammersley, M. (1992). What's wrong with ethnography? Methodological explorations. London: Routledge.

Harvey, D. (1989). The condition of postmodernity. Oxford: Blackwell.

Hellekjær, G. O. (2007). Fremmedspråk i norsk næringsliv - engelsk er ikke nok! (Vol. 3). Halden: Fremmedspråksenteret.

Homme Holstad, B. (2012). Språk $i$ et globalisert noeringsliv: Bruk av norsk og engelsk $i$ maritim industrisektor [Language in globalised business: Use of Norwegian and English in maritime industry sector]. MA thesis, University of Oslo.

International Phonetic Association. (1999). Handbook of the International Phonetic Association: A guide to the use of the International Phonetic Alphabet. Cambridge: Cambridge University Press. 
Irvine, J. T., \& Gal, S. (2000). Language ideology and linguistic differentiation. In P. V. Kroskrity (Ed.), Regimes of language: Ideologies, polities, and identities (pp. 35-84). Santa Fe, NM: School of American Research Press.

ITU Monitor. (2009). The digital state of affairs in Norwegian schools 2009: The Network for IT Research and Competence in Education (ITU).

Jahr, E. H., \& Mæhlum, B. (issue editors) (2009). Norsk Lingvistisk Tidsskrift, 27(1), Special issue on spoken standard.

Jenkins, J. (2006a). Current perspectives on teaching World Englishes and English as a Lingua Franca. TESOL Quarterly, 40(1), 157-181.

Jenkins, J. (2006b). English pronunciation and second language speaker identity. In T. Omoniyi \& G. White (Eds.), Sociolinguistics of identity (pp. 75-91). London and New York: Continuum.

Jenkins, J. (2007). English as a lingua franca: Attitude and identity. Oxford: Oxford University Press.

Jenkins, J., Cogo, A., \& Dewey, M. (2011). Review of developments in research into English as a lingua franca. Language Teaching, 44(3), 281-315.

Johnson, K. (2008). Quantitative methods in linguistics. USA, UK and Australia: Blackwell.

Johnson, R. B., \& Onwuegbuzie, A. J. (2004). Mixed methods research: A research paradigm whose time has come. Educational Researcher, 33(7), 14-26.

Kachru, B. (1985). Standards, codification and sociolinguistic realism: The English language in the outer circle. In R. Quirk \& H. G. Widdowson (Eds.), English in the world: Teaching and learning the language and literatures (pp. 11-30). Cambridge: Cambridge University Press.

Kachru, B. (1992). World Englishes: Approaches, issues, and resources. Language Teaching, $25,1-14$.

Kachru, B., Kachru, Y., \& Nelson, C. (Eds.). (2006). The handbook of World Englishes. Malden, MA: Blackwell.

Kanno, Y., \& Norton, B. (issue editors) (2003). Imagined communities and educational possibilities. Journal of Language, Identity \& Education, 2(4), Special issue on imagined communities.

KD. (2006). National Curriculum for Knowledge Promotion in Primary and Secondary Education and Training. English subject curriculum. Oslo: Ministry of Education and Research Retrieved from http://www.udir.no/Stottemeny/English/Curriculum-inEnglish/.

Kirkpatrick, A. (2010a). Introduction. In A. Kirkpatrick (Ed.), The Routledge handbook of World Englishes. London: Routledge.

Kirkpatrick, A. (Ed.). (2010b). The Routledge handbook of World Englishes. London: Routledge.

Kleven, T. A. (2008). Validity and validation in qualitative and quantitative research. Nordic Educational Research (Nordisk Pedagogik), 28, 219-233.

Kramsch, C. (2006). The multilingual subject. International Journal of Applied Linguistics, 16(1), 97-110.

Kramsch, C. (2009). The multilingual subject. What language learners say about their experiences and why it matters. Oxford: Oxford University Press.

Kristiansen, T. (2001). Two standards: One for the media and one for the school. Language Awareness, 10(1), 9-24.

Kristiansen, T. (2005) The power of tradition. A study of attitudes towards English in seven nordic communities. In T. Kristiansen, P. Garrett \& N. Coupland (Series Ed.), Acta Linguistica Hafniensia: Vol. 37. Subjective processes in language variation and change (pp. 155-169). 
Kristiansen, T. (2010) Conscious and subconscious attitudes towards English influence in the Nordic countries: Evidence for two levels of language ideology. In T. Kristiansen \& H. Sandøy (Series Ed.), The International Journal of the Sociology of Language: Vol. 204. The linguistic consequences of globalization: The Nordic countries (pp. 59-95).

Kristiansen, T. (2011). Attitudes, ideology and awareness. In R. Wodak, B. Johnstone \& P. Kerswill (Eds.), The SAGE handbook of sociolinguistics: SAGE.

Kristiansen, T., Garrett, P., \& Coupland, N. (2005). Introducing subjectivities in language variation and change. Acta Linguistica Hafsniensia, 37, 9-35.

Kristiansen, T., \& Sandøy, H. (2010) Introduction. The linguistic consequences of globalization: The Nordic laboratory. In T. Kristiansen \& H. Sandøy (Series Ed.), The International Journal of the Sociology of Language: Vol. 204. The linguistic consequences of globalization: The Nordic countries (pp. 1-7).

Kristiansen, T., \& Vikør, L. S. (2006a). Nordiske språkhaldningar - jamføring og konklusjonar [Nordic language attitudes - summary and conclusions]. In T. Kristiansen \& L. S. Vikør (Eds.), Nordiske språkhaldningar. Ei meiningsmåling [Nordic language attitudes. A survey] (pp. 199-214). Oslo: Novus.

Kristiansen, T., \& Vikør, L. S. (Eds.). (2006b). Nordiske språkhaldningar. Ei meiningsmåling [Nordic language attitudes. A survey]. Oslo: Novus.

Kristoffersen, G. (2000). The phonology of Norwegian. Oxford: Oxford University Press.

Kvale, S., \& Brinkmann, S. (2008). InterViews: Learning the craft of qualitative interviewing (2nd ed.). Los Angeles: Sage Publications.

Labov, W. (1966). The social stratification of English in New York City. New York: Center for Applied Linguistics.

Ladegaard, H., J. (1998). National stereotypes and language attitudes: The perception of British, American and Australian language and culture in Denmark. Language and Communication, 18(4), 251-274.

Lantolf, J. P. (2006). Sociocultural theory and second language learning: State of the art. Studies in Second Language Acquisition, 28, 67-109.

Le Page, R. B., \& Tabouret-Keller, A. (1985). Acts of identity. Cambridge: Cambridge University Press.

Linell, P. (2009). Rethinking language, mind, and world dialogically: Interactional and contextual theories of human sense-making. Charlotte, NC: Information Age Publishing.

Ljosland, R. (2008). Lingua franca, prestisjespråk og forestilt fellesskap: Om engelsk som akademisk språk $i$ Norge [Lingua franca, prestige language and imagined community: About English as academic language in Norway]. Ph.D. dissertation, NTNU, Trondheim.

Ljosland, R. (2010). Teaching through English: Monolingual policy meets multilingual practice. Hermes - Journal of Language and Communication Studies, 45, 99-113.

Llamas, C. (2006). Shifting identities and orientations in a border town. In T. Omoniyi \& G. White (Eds.), Sociolinguistics of identity (pp. 92-112). London and New York: Continuum.

Llamas, C., \& Watt, D. (Eds.). (2010). Language and Identities. Edinburgh: Edinburgh University Press.

Locher, M. A., \& Strässler, J. (Eds.). (2008). Standards and norms in the English language. Berlin and New York: Mouton de Gruyter.

Lund, A. (2006). The multiple contexts of online language teaching. Language Teaching Research, 10(2), 181-204.

Maegaard, M. (2005). Language attitudes, norm and gender: A presentation of the method and results from a language attitude study. Acta Linguistica Hafsniensia, 37, 55-80. 
Maegaard, M. (2007). Udtalevariation og -forandring i københavnsk - en etnografisk undersøgelse af sprogbrug, sociale kategorier og social praksis blandt unge på en københavnsk folkeskole [Variation and change in pronunciation in Copenhagen - an ethnographic study of language use, social categories and social practice among youth in a Copenhagen school]. (Doctoral dissertation). Københavns Universitet, Copenhagen.

Mauranen, A., \& Ranta, E. (Eds.). (2009). English as a lingua franca: Studies and findings. Newcastle upon Tyne: Cambridge Scholars Publishing.

Menard-Warwick, J. (2005). Both a fiction and an existential fact: Theorizing identity in second language acquisition and literacy studies. Linguistics and Education, 16, 253274.

Milroy, J. (2007). The ideology of the standard language. In C. Llamas, L. Mullany \& P. Stockwell (Eds.), The Routledge companion to sociolinguistics (pp. 133-139). London and New York: Routledge.

Ministry of Education and Research. (2012). Tilstandsrapport: Høyere utdanning 2012 [Survey report: Higher education 2012].

Mjaaland, O. (2011, 24th september). Elevene deles av elven [The students are divided by the river], Aftenposten, p. 12.

Moore, E. (2004). Sociolinguistic style: A multidimensional resource for shared identity creation. Canadian Journal of Linguistics, 49, 375-396.

Moore, E. (2010). Interaction between social category and social practice: Explaining was/were variation. Language Variation and Change, 22(3), 347-371.

Moore, E. (2012). The social life of style. Language and Literature, 21(1), 66-83.

Mufwene, S. S. (2010). Globalization, Global English, and World English(es): Myths and facts. In N. Coupland (Ed.), The handbook of language and globalization (pp. 31-55). Chichester: Wiley-Blackwell.

Mæhlum, B. (1992). Dialektal sosialisering. En studie av barn og ungdoms språklige strategier i Longyearbyen på Svalbard [Dialectal socialisation: A study of language strategies among children and adolescents in Longyearbyen on Svalbard]. Oslo: Novus.

Mæhlum, B., \& Røyneland, U. (2009). Dialektparadiset Norge - en sannhet med modifikasjoner [The dialect paradise Norway - a truth with modifications]. In H. Hovmark, I. S. Sletten \& A. Gudiksen (Eds.), I Mund og bog. 25 artikler om sprog tilegnet Inge Lise Pedersen på 70-årsdagen d. 5. juni 2009. Afdeling for Dialektforskning, Nordisk Forskningsinstitut, Københavns Universitet.

NESH. (2006). Guidelines for research ethics in the social sciences, law and the humanities. The National Committees of Research Ethics.

Norton, B. (2000). Identity and language learning. London: Longman.

Norton, B. (2001). Non-participation, imagined communities, and the language classroom. In M. Breen (Ed.), Learner contributions to language learning: New directions in research (pp. 159-171). London: Pearson Education Limited.

Norton, B., \& Toohey, K. (2011). Identity, language learning, and social change. Language Teaching, 44(4), 412-446.

Norton Pierce, B. (1995). Social identity, investment, and language learning. TESOL Quarterly, 29(1), 9-31.

Ochs, E. (1992). Indexing gender. In A. Duranti \& C. Goodwin (Eds.), Rethinking context: Language as an interactive phenomenon (pp. 335-358). Cambridge: Cambridge University Press.

OECD. (2011). Education at a glance 2011: OECD indicators. OECD Publishing. 
Omoniyi, T., \& White, G. (Eds.). (2006). Sociolinguistics of identity. London and New York: Continuum.

Opsahl, T. (2009). "Egentlig alle kan bidra!" - en samling sosiolingvistiske studier av strukturelle trekk ved norsk i multietniske ungdomsmiljøer i Oslo [Acutally everybody may contribute! - A collection of sociolinguistic studies of structural features associated with Norwegian as spoken among adolescents in multethnic areas in Oslo]. (Doctoral dissertation). University of Oslo, Oslo.

Oslo Kommune. (2012). Statistical yearbook of Oslo 2011. The Municipality of Oslo. Oslo: Oslo Kommune.

Pennycook, A. (2005). Global and worldly Englishes: Discommunities and subcultural empires. Paper presented at the Institute of European Studies, Berkely, CA, February, Berkely, CA.

Phillipson, R. (1992). Linguistic imperialism. Oxford \& New York: Oxford University Press.

Phillipson, R. (2003). English-only Europe? Challenging language policy. London: Routledge.

Podesva, R. J. (2007). Phonation type as a stylistic variable: The use of falsetto in constructing a persona. Journal of Sociolinguistics, 11(4), 478-504.

Primary and Lower Secondary Education Act, Act no 24 of 13 June 1969 concerning primary and lower secondary education.

Quist, P. (2005). Stilistiske praksisser i storbyens heterogene skole - en etnografisk og sociolingvistisk undersøgelse af sproglig variation [Stylistic practices in the urban, heterogeneous high school - an ethnographic and sociolinguistic study of language variation]. Ph.D. dissertation, Københavns Universitet, Copenhagen.

Quist, P. (2008). Sociolinguistic approaches to multiethnolect: Language variety and stylistic practice. International Journal of Bilingualism, 12(1-2), 43-61.

Rampton, B. (2005). Crossing: Language and ethnicity among adolescents (2nd ed.). Manchester: St. Jerome.

Roach, P., Setter, J., \& Esling, J. (Eds.). (2011) Cambridge English Pronouncing Dictionary Daniel Jones (18th ed.). Cambridge: Cambridge University Press.

Røyneland, U. (2005). Dialektnivellering, ungdom og identitet: Ein komparativ studie av språkleg variasjon og endring i to tilgrensande dialektområde, Røros og Tynset [Dialect levelling, adolescents and identity]. (Doctoral dissertation). Oslo: Acta Humaniora.

Røyneland, U. (2010). Vertical convergence of linguistic varieties in a language space. In P. Auer \& J. E. Schmidt (Eds.), Language and space: An international handbook of linguistic variation (pp. 259-274). Berlin and New York: Mouton de Gruyter.

Sandøy, H. (2007). Avisspråket i Norden - ei jamføring [The newspaper language in the Nordic countries - a summary]. In B. Selback \& H. Sandøy (Eds.), Fire dagar $i$ nordiske aviser [Four days in Nordic newspapers] (pp. 127-155). Oslo: Novus.

Sandøy, H. (2011). Language culture in Norway: A tradition of questioning standard language norms. In T. Kristiansen \& N. Coupland (Eds.), Standard languages and language standards in a changing Europe. Oslo: Novus Press.

Sarnoff, I. (1970). Social attitudes and the resolution of motivational conflict. In M. Jahoda \& N. Warren (Eds.), Attitudes (pp. 279-284). Harmondsworth: Penguin.

Schwach, V., \& Dalseng, C. F. (2011). Språk i pensumlitteratur [Language in curriculum material]: NIFU.

Seidlhofer, B. (2001). Closing a conceptual gap: The case for a description of English as a Lingua Franca. International Journal of Applied Linguistics, 11(2), 133-158.

Seidlhofer, B. (2010). Lingua franca English in Europe. In A. Kirkpatrick (Ed.), The Routledge handbook of World Englishes (pp. 355-371). London: Routledge. 
Seidlhofer, B. (2011). Understanding English as a lingua franca. Oxford: Oxford University Press.

Selback, B., \& Kristiansen, T. (2006). Noreg [Norway]. In T. Kristiansen (Ed.), Nordiske sprogholdninger. En masketest [Nordic language attitudes. A matched-guise test] (pp. 65-82). Oslo: Novus.

Selback, B., \& Sandøy, H. (Eds.). (2007). Fire dagar i nordiske aviser [Four days in Nordic newspapers]. Oslo: Novus.

Sharma, D. (2005). Dialect stabilization and speaker awareness in non-native varieties of English. Journal of Sociolinguistics, 9(2), 194-224.

Sharma, D. (2011). Style repertoire and social change in British Asian English. Journal of Sociolinguistics, 15(4), 464-492.

Silverman, D. (2006). Interpreting qualitative data. Methods for analyzing talk, text and interaction (3. ed.). Los Angeles: Sage Publications.

Silverstein, M. (1979). Language structure and linguistic ideology. In P. R. Clyne, W. F. Hanks \& C. L. Hofbauer (Eds.), The elements: A parasession on linguistic units and levels (pp. 193-247). Chicago: Chicago Linguistic Society.

Silverstein, M. (1985). Language and the culture of gender: At the intersection of structure, usage, and ideology. In E. Mertz \& R. J. Parmentier (Eds.), Semiotic mediation: Sociocultural and psychological perspectives (pp. 219-259). Orlando, FL: Academic Press.

Simensen, A. M. (2011). Europeiske institusjoners rolle i utviklingen av engelskfaget i norsk skole [The role of European institutions in the development of the English subject in Norwegian schools]. Didaktisk Tidskrift, 20(3), 157-181.

Solberg, H. (2001). Teaching English in a multicultural classroom. Språk og språkundervisning, 3, 20-25.

Språkrådet. (2011). Språkstatus 2011: Språkpolitisk tilstandsrapport fra Språkrådet: Språkrådet (The Language Council of Norway).

Stuart-Smith, J. (2007). The influence of the media. In C. Llamas, P. Stockwell \& L. Mullany (Eds.), The Routledge companion to sociolinguistics (pp. 140-148). London: Routledge.

Stuart-Smith, J. (2011). The view from the couch: Changing perspectives on the role of television in changing language ideologies and use. In T. Kristiansen \& N. Coupland (Eds.), Standard languages and language standards in a changing Europe (pp. 223239). Oslo: Novus.

Stuart-Smith, J. (2012). English and the media: Television. In A. Bergs \& L. J. Brinton (Eds.), English historical linguistics: An international handbook. Berlin: De Gruyter Mouton.

Stuart-Smith, J., Timmins, C., \& Alam, F. (2011). Hybridity and ethnic accents: A sociophonetic analysis of 'Glaswasian'. In F. Gregersen, J. K. Parrott \& P. Quist (Eds.), Language variation - European perspectives 3: Selected papers from the 5th International Conference on Language Variation in Europe (ICLaVE 5), Copenhagen, June 2009 (pp. 43-57). Amsterdam/Philadelphia: John Benjamins Publishing Company.

Svendsen, B. A., \& Røyneland, U. (2008). Multiethnolectal facts and functions in Oslo, Norway. International Journal of Bilingualism, 12(1\&2), 63-83.

Tajfel, H., \& Turner, J. (1979). An integrative theory of intergroup conflict. In W. G. Austin \& S. Worchel (Eds.), The social psychology of intergroup relations (pp. 33-47). Monterey, CA: Brooks/Cole.

Tashakkori, A., \& Teddlie, C. (1998). Mixed methodology: Combining qualitative and quantitative approaches (Vol. 46). Thousand Oaks, California: SAGE Publications. 
Trudgill, P. (2000). Sociolinguistics: An introduction to language and society (4th ed.). Harmondsworth: Penguin.

Tupas, T. R. F. (2010). Which norms in everyday practice - and why? In A. Kirkpatrick (Ed.), The Routledge handbook of World Englishes. London and New York: Routledge.

University of Oslo. (2012). ENG1103 - English phonetics and intonation, an introduction Retrieved Accessed on 04.10.2012, from http://www.uio.no/studier/emner/hf/ilos/ENG1103/index-eng.xml

Verschueren, J. (Ed.). (1999). Language and ideology. Selected papers from the 6th International Pragmatics Conference (Vol. 1). Antwerp: International Pragmatics Association.

Vygotsky, L. S. (1978). Mind in society: The development of higher psychological processes. Cambridge, MA: Harvard University Press.

Vygotsky, L. S. (1987). Thinking and speech (N. Minick, Trans.). In R. W. Rieber \& A. S. Carton (Eds.), The collected works of L. S. Vygotsky (Vol. 1, pp. 39-285). New York and London: Plenum.

Weedon, C. (1987). Feminist practice \& poststructuralist theory. Oxford: Blackwell.

Wells, J. C. (1982). Accents of English. Cambridge: Cambridge University Press.

Wenger, E. (1998). Communities of Practice: Learning, Meaning and Identity. Cambridge: Cambridge University Press.

Øia, T. (2007). Ung i Oslo: Levekår og sosiale forskjeller [Young in Oslo: Living conditions and social differences]. Oslo: NOVA. 


\section{Appendix}

\section{APPENDIX 1: Abbreviations}

CLT Communicative language teaching

DS1 Data set 1

DS2 Data set 2

EA Extended Abstract

EFL English as a foreign language

ELF English as a lingua franca

ELT English language teaching

ESL English as a second language

GenAm General American

L1 First language

L2 Second (additional) language

MGT Matched-guise test/technique

RP Received Pronunciation

RQ Research question

SLA Second language acquisition

SSBE Standard Southern British English

UEN Urban East Norwegian

VGT Verbal-guise test/technique

WE World Englishes

AmE aimers/US aimers Participants who reported in the questionnaire to aim towards an American English accent

BrE aimers/GB aimers Participants who reported in the questionnaire to aim towards a British English accent

Neutral aimers Participants who reported in the questionnaire to aim towards a 'Neutral' accent of English 
APPENDIX 2: Stimulus text for the verbal-guise test, Data set 2

The North Wind and the Sun

The North Wind and the Sun were arguing one day about which of them was stronger, when a traveller came along wrapped up in an overcoat. They agreed that the one who could make the traveller take his coat off would be considered stronger than the other one.

Then the North Wind blew as hard as he could, but the harder he blew, the tighter the traveller wrapped his coat around him; and at last the North Wind gave up trying.

Then the Sun began to shine hot, and right away the traveller took his coat off. And so the North Wind had to admit that the Sun was stronger than he was.

(as read in the AUE Audio Archive, transcribed by Dr Lucinda Hart-Gonzalez. From The Principles of the International Phonetics Association, 1949) 
APPENDIX 3: The instructions and design of the identification test. English translation in italics

Del 2 - Identifiseringsskjema

Part 2 - Identification form

Nå får du høre de samme opptakene igjen, men bare halve opptaket og i en annen rekkefølge. Hvilke engelskspråklige land tror du de forskjellige personene er fra? (Hvis du krysser av for Annet land, skriv hvilket land du tror personen er fra.)

NB: Ikke alle engelskspråklige land er representert, og det er ikke sikkert antallet personer fra ulike land er jevnt fordelt. Ikke tenk strategisk!

Now you get to hear the same recordings again, but only half the recording and in another order. Which English-speaking countries do you think the different people come from? (If you check the Other country box, write which country you think this person is from.)

Note: Not all English-speaking countries are represented, and the number of people from different countries might not be evenly distributed. Don't think strategically!

\begin{tabular}{|c|c|c|c|}
\hline Opptak 1: & $\square$ England & $\square$ USA & $\square$ Annet land: \\
\hline Recording 1: & $\square$ England & $\square U S A$ & Other country: \\
\hline Opptak 2: & $\square$ England & $\square$ USA & $\square$ Annet land: \\
\hline Recording 2: & $\square$ England & $\square U S A$ & $\square$ Other country: \\
\hline
\end{tabular}

Etc... 


\section{APPENDIX 4: Results parametric and non-parametric tests}

Effect of accent aim on variant production for Data set $1(\mathrm{~N}=19)$. Data are presented as word list and conversations combined, as in Article 1.

\begin{tabular}{llll}
\hline Variable & Result & T-test & Mann-Whitney \\
\hline $\begin{array}{l}\text { Non-prevocalic } \\
\text { r/ } /\end{array}$ & $\begin{array}{l}\text { AmE aimers more }[\mathrm{r}] \text { than BrE } \\
\text { aimers }\end{array}$ & $\begin{array}{l}t(17)=2.858, \\
\mathrm{p}=.011\end{array}$ & $U=13.5, \mathrm{p}=.012$ \\
\hline Intervocalic $/ \mathrm{t} /$ & $\begin{array}{l}\text { AmE aimers more }[\mathrm{r}] \text { than BrE } \\
\text { aimers }\end{array}$ & $\begin{array}{l}t(17)=2.912, \\
\mathrm{p}=.010\end{array}$ & $U=19, \mathrm{p}=.039$ \\
\hline GOAT & $\begin{array}{l}\text { AmE aimers more }[\mathrm{ov}] \text { than BrE } \\
\text { aimers }\end{array}$ & $\begin{array}{l}t(17)=2.230, \\
\mathrm{p}=.040\end{array}$ & $U=17, \mathrm{p}=.022$ \\
\hline LOT & $\begin{array}{l}\text { AmE aimers more }[\mathrm{a}] \text { than BrE } \\
\text { aimers }\end{array}$ & $\begin{array}{l}t(17)=2.668, \\
\mathrm{p}=.016\end{array}$ & $U=16, \mathrm{p}=.021$ \\
\hline
\end{tabular}

Effect of accent aim on variant production for Data set $2(\mathrm{~N}=62 / 54)$. Data are presented as word list $(\mathrm{N}=62)$ and conversations $(\mathrm{N}=54)$ separately, as in Article 3.

\begin{tabular}{|c|c|c|c|}
\hline Variable & Result & $\begin{array}{l}\text { One-way } \\
\text { ANOVA }\end{array}$ & $\begin{array}{l}\text { Kruskal- } \\
\text { Wallis }\end{array}$ \\
\hline BATH (wordlist) & $\begin{array}{l}\text { AmE aimers more }[æ] \text { than } \\
\text { BrE aimers }\end{array}$ & $\begin{array}{l}F(2,59)=9.545 \\
\mathrm{p}=.000\end{array}$ & $\begin{array}{l}H(2)=14.230 \\
\mathrm{p}=.001\end{array}$ \\
\hline BATH (conversations) & $\begin{array}{l}\text { AmE aimers more }[æ] \text { than } \\
\text { BrE aimers }\end{array}$ & $\begin{array}{l}F(2,50)=8.328 \\
\mathrm{p}=.001\end{array}$ & $\begin{array}{l}H(2)=11.223 \\
\mathrm{p}=.004\end{array}$ \\
\hline LOT (wordlist) & $\begin{array}{l}\text { AmE aimers more }[a] \text { than } \\
\text { BrE aimers }\end{array}$ & $\begin{array}{l}F(2,59)=17.461, \\
\mathrm{p}=.000\end{array}$ & $\begin{array}{l}H(2)=21.806 \\
\mathrm{p}=.000\end{array}$ \\
\hline LOT (conversations) & $\begin{array}{l}\text { AmE aimers more }[a] \text { than } \\
\text { BrE aimers }\end{array}$ & $\begin{array}{l}F(2,51)=7.775 \\
\mathrm{p}=.001\end{array}$ & $\begin{array}{l}H(2)=13.544, \\
\mathrm{p}=.001\end{array}$ \\
\hline GOAT (wordlist) & $\begin{array}{l}\text { AmE aimers more [o-] than } \\
\text { BrE aimers }\end{array}$ & $\begin{array}{l}F(2,59)=5.479 \\
\mathrm{p}=.007\end{array}$ & $\begin{array}{l}H(2)=8.972 \\
\mathrm{p}=.011\end{array}$ \\
\hline GOAT (conversations) & $\begin{array}{l}\text { AmE aimers more [o-] than } \\
\text { BrE aimers* }\end{array}$ & $\begin{array}{l}F(2,51)=2.669 \\
\mathrm{p}=.079\end{array}$ & $\begin{array}{l}H(2)=7.474 \\
\mathrm{p}=.024\end{array}$ \\
\hline $\begin{array}{l}\text { Non-prevocalic /r/ } \\
\text { (wordlist) }\end{array}$ & $\begin{array}{l}\text { AmE aimers more }[r] \text { than } \\
\text { BrE aimers }\end{array}$ & $\begin{array}{l}F(2,59)=3.907 \\
\mathrm{p}=.026\end{array}$ & $\begin{array}{l}H(2)=9.055 \\
\mathrm{p}=.011\end{array}$ \\
\hline $\begin{array}{l}\text { Non-prevocalic } / \mathrm{r} / \\
\text { (conversations) }\end{array}$ & $\begin{array}{l}\text { AmE aimers more }[\mathrm{r}] \text { than } \\
\text { BrE aimers }\end{array}$ & $\begin{array}{l}F(2,51)=5.576 \\
\mathrm{p}=.006\end{array}$ & $\begin{array}{l}H(2)=12.704, \\
\mathrm{p}=.002\end{array}$ \\
\hline $\begin{array}{l}\text { Intervocalic /t/ } \\
\text { (wordlist) }\end{array}$ & $\begin{array}{l}\text { AmE aimers more }[r] \text { than } \\
\text { BrE aimers }\end{array}$ & $\begin{array}{l}F(2,59)=3.631 \\
\mathrm{p}=.033\end{array}$ & $\begin{array}{l}H(2)=6.952 \\
\mathrm{p}=.031\end{array}$ \\
\hline $\begin{array}{l}\text { Intervocalic /t/ } \\
\text { (conversations) }\end{array}$ & & $\begin{array}{l}F(2,51)=1.247 \\
\mathrm{p}=.296\end{array}$ & $\begin{array}{l}H(2)=2.397 \\
\mathrm{p}=.302\end{array}$ \\
\hline $\begin{array}{l}\text { Post-coronal /j/ } \\
\text { (wordlist) }\end{array}$ & & $\begin{array}{l}F(2,59)=1.509 \\
\mathrm{p}=.230\end{array}$ & $\begin{array}{l}H(2)=3.876 \\
\mathrm{p}=.144\end{array}$ \\
\hline $\begin{array}{l}\text { Post-coronal /j/ } \\
\text { (conversations) }\end{array}$ & & $\begin{array}{l}F(2,40)=0.025, \\
\mathrm{p}=.975\end{array}$ & $\begin{array}{l}H(2)=0.256 \\
\mathrm{p}=.880\end{array}$ \\
\hline Voiceless th (wordlist) & $\begin{array}{l}\text { AmE aimers more }[\theta] \text { than } \\
\text { BrE/Neutral aimers* }\end{array}$ & $\begin{array}{l}F(2,51)=2.743 \\
\mathrm{p}=.074\end{array}$ & $\begin{array}{l}H(2)=6.686 \\
\mathrm{p}=.035\end{array}$ \\
\hline
\end{tabular}

$* \mathrm{p}<.05$ for non-parametric test only 


\section{APPENDIX 5: Questionnaire, Data set 1}

1. Name:

2. Class:

3. Apart from English, what other subjects have you chosen for this school year?

4. Where did you grow up? (If you grew up in Oslo, please specify which part of town)

5. Have you ever visited or lived in an English-speaking country? If yes, where? For how long?

6. Does your father or mother have English as a native language? Please explain.

7. What is your father's occupation and/or education?

8. What is your mother's occupation and/or education?

9. What do you plan to do after upper secondary school?

10. Which profession would you like to have?

11 . What is your last average term grade?

12. How many hours a week do you spend on homework?

13. Are you a member of an organization or society in your school? If yes, which?

14. What do you do in school breaks, and in which areas of the school do you normally spend time if you are not in class (cafeteria, school yard, classroom etc)?

15. What do you do after school and in weekends, and where do you spend most of your spare time (home, café, city centre, etc)?

16. Please explain your "style": What clothes, shoes, accessories etc. do you normally wear?

17. Do you smoke?

18. Do you drink alcohol?

Circle one alternative for the following questions:

19. How many hours a week do you listen to music with English lyrics?

none $\quad 1-5 \quad 6-10 \quad 11-15 \quad 16-21 \quad$ more than 21

20. What kind of music have you listened to the most during the last 2-3 years? rap/hiphop/R\&B pop/rock both categories other

21. Who is your favourite artist?

22. How many hours a week do you watch American TV/films/cinema?

none $\quad 1-5 \quad 6-10 \quad 11-15 \quad 16-21 \quad$ more than 21

23. How many hours a week do you watch British TV/films/cinema? 
none $\quad 1-5 \quad 6-10 \quad 11-15 \quad 16-21 \quad$ more than 21

24. If you had to choose, where would you rather move? the US Great Britain

25. If you had to choose, who would you rather marry? an American a Brit

26. Which accent/pronunciation did your English teacher last year have?

American British Norwegian other

27. Which accent/pronunciation have most of your teachers had in primary and lower secondary school?

American British American and British other

28. In your opinion, which accent/pronunciation is favoured when teaching English in Norwegian schools?

American British American and British Norwegian other

29. Which accent/pronunciation are you aiming at when you speak English?

American English British English other don't care

30. If you answered American English or British English on the previous question, why do you not aim at the other accent?

31. Is one of the accents more difficult to speak than the other? Please explain. 


\section{APPENDIX 6: Questionnaire, Data set 2}

Dear student,

Here are some questions about you and what you think about English. This is not a test - we are interested in what you personally think. Please take your time, and do not hesitate to ask if you have any questions!

\section{SOME QUESTIONS ABOUT YOU AND YOUR BACKGROUND}

1. $\square$ Male $\square$ Female

2. Where did you grow up?

$\square$ Østlandet

$\square$ Sørlandet

$\square$ Vestlandet

$\square$ Nord-Norge

$\square$ Abroad: Where?

3. Do you have another first language than Norwegian (Do you speak another language at home, in addition to or instead of Norwegian)? $\square$ Yes $\square$ No

If Yes: Please write your (additional) first language:

4. From which grade/year have you gone to school in Norway?

$\square$ School year 1

$\square$ School year 4 or before

$\square$ School year 7 or before

School year 10 or before

$\square \mathrm{Vg} 1$

5. What is your parents' highest level of education? (Give one answer for each parent)
Mother Father
Lower secondary school (ungdomsskolen)
Upper secondary school (videregående)
University education (universitet eller høyskole)
(Bachelor or higher degree)

6. Which year of Upper Secondary School (Videregående skole) are you in?

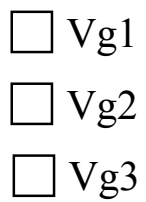


7. Which Education Programme (Utdanningsprogram) are you in?

$\square$ Specialization in General Studies (Studiespesialiserende)

$\square$ Music, Dance and Drama (Musikk, dans og drama)

$\square$ Sports and Physical Education (Idrettsfag)

$\square$ External Candidate (Privatistelev)

$\square$ Other:

8. If you are in the program Specialization in General Studies (Studiespesialiserende), which program area (programområde) are you in?

$\square$ Natural Science and Mathematics Studies (Realfag)

$\square$ Languages, Social Sciences and Economics Studies (Språk, samfunnsfag og økonomi)

$\square$ Art, Craft and Design Studies (Formgivingsfag)

$\square$ Other:

9. Do you intend to go on to higher education? $\square$ Yes $\square$ No

10. Which job would you like to have in the future? (You may give several answers)

11. Do you intend to study or work outside Norway? (Give only one answer)

$\square$ No

$\square$ Yes, in an English speaking country. Which?

Yes, in a non-English speaking country. Which?

12. How many hours per week do you spend doing homework (in sum for all subjects)?

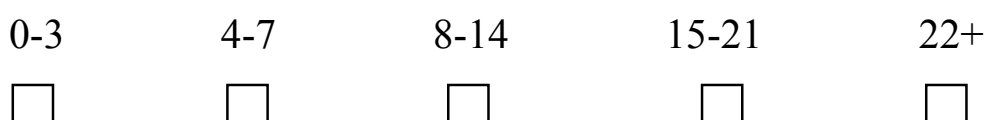

13. How important is achieving good grades to you?

Not important

at all
Very important
$\square 1$
$\square 2$
$\square 3$
$\square 4$

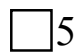

14. Are you a member of one or more organization(s) (including activities organized through your school)?
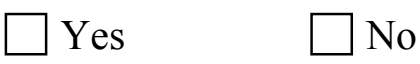

If yes, what kind of organization, and which? (You may give several answers)

\section{Political:}

Environmental:

Sports:

$\square$ Music/Performance/Arts:

Academic: 
$\square$ Religious:

Social work:

15. Are you a member of an online community, such as Facebook, World of Warcraft, Counter Strike or Blogspot.com? If yes, which? (You may give several answers)

$\square$ Yes:

$\square$ No

\section{SOME QUESTIONS ABOUT YOUR BACKGROUND IN ENGLISH}

16. Have you ever lived in or visited English-speaking countries? If yes, how long was your longest coherent stay?

Never 3 weeks or less 1-3 months 3-12 months 1 year +

17. Do you have any other special background in English? (you may give several answers)

$\square$ I have no special English background.

$\square$ One or both of my parents are speakers of English as their first language.

$\square$ I have had schooling in an English-speaking country (6 months or more)

$\square$ I have attended an English language upper secondary school in Norway

$\square$ I have a different background in English. (Please describe)

18. How often do you speak English on your spare time (for example with friends, at home, at work etc)?

Never Very rarely 1-2 times a month 1-2 times a week Every day

19. What grade did you achieve in English last term? (Give only one answer)

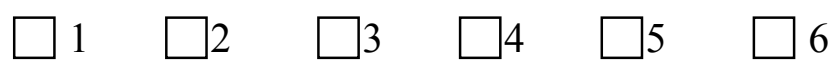

20. How many hours per week do you use the following media when English is the dominant language?

$\begin{array}{lccccc} & 0-3 & 4-7 & 8-14 & 15-21 & 22+ \\ \text { Films on DVD or cinema } & \square & \square & \square & \square & \square \\ \text { TV } & \square & \square & \square & \square & \square \\ \text { Internet } & \square & \square & \square & \square & \square \\ \text { Computer games } & \square & \square & \square & \square & \square \\ \text { Books } & \square & \square & \square & \square & \square \\ \text { Magazines/newspapers } & \square & \square & \square & \square & \square\end{array}$


Music

\section{SOME QUESTIONS ABOUT WHAT YOU THINK ABOUT ENGLISH}

21. How interested are you in English as a school subject?

Not interested

at all
Very

interested

22. If you had to choose, to where would you rather move? $\square$ the US $\square$ Great Britain

23. When you read a text or watch a programme on TV dealing with the history and culture of an English-speaking country, which country do you prefer to read/hear/learn about? (Give only one answer)

$\square$ the US $\square$ Great Britain $\square$ Other:

Why?

24. We are interested in your opinion about where you have learnt English. How much of your English knowledge have you acquired through school instruction, how much through the media, and how much in other ways? Give your answers in percent. Make sure the total adds up to $100 \%$ !

Through school:

\begin{tabular}{l}
$\%$ \\
\hline
\end{tabular}

In other ways: $\%$ Specify:

$$
=100 \%
$$

25. Which accent/pronunciation do you think your present English teacher has? (Give only one answer)

American British Norwegian "Neutral" Other I don't know

26. Which accent/pronunciation have most of your previous English teachers had throughout your years in Norwegian schools? (Give only one answer)

American British Norwegian "Neutral" Other I don't know

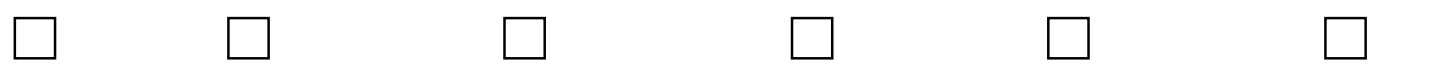

27. In your opinion, which accent/pronunciation is favoured when teaching English in Norwegian schools? (Give only one answer)

American British American \& British Norwegian "Neutral" Other I don't know 
28. Which accent/pronunciation are you aiming at when you speak English? (Give only one answer)

American British Norwegian "Neutral" Other I don't care

29. If you answered American English on the previous question, why do you not aim at British English? If you answered British English on the previous question, why do you not aim at American English?

30. Is one of the accents (American or British) more difficult to speak than the other? Please explain.

THANK YOU! 
APPENDIX 7: Excerpts from interviews, used in the EA and in the articles, in the original wording and translated into English.

Excerpts in Article 1 which are not given in the original here, are in fact the participants' original responses, since the questionnaire was given in English.

\section{C21 (Neutral aimer, excerpt used in EA 6.1, and in Articles 2 and 3)}

hvis jeg plutselig skulle begynne å snakke britisk så ville det bare vært rart fordi jeg bor ikke i Storbritannia jeg er ikke brite og jeg er ikke påvirket av britisk kultur i det hele tatt liksom, så det ville liksom forandret på deler av identiteten

$[\ldots]$

jeg tror mange av oss også vil være nøytrale fordi jeg vil liksom bli oppfattet som en som faktisk kan språket ikke sånn jeg vil liksom ikke bli oppfattet som en amerikaner eller som en brite

if I suddenly should have started speaking British then that would just be weird because I don't live in Great Britain I'm not a Brit and I'm not influenced by British culture, like, at all, so that would, like, change parts of the identity

[...]

I think many of us want to be neutral because I want to, like, be thought of as someone who actually knows the language [...] I don't want to, like, be thought of as an American or a Brit

\section{C02 (Neutral aimer, excerpt used in EA 6.1 and in Article 3)}

jeg snakker på en måte det jeg har lært og det jeg har plukket opp litt her og litt der I speak, in a way, what I've learnt and what I've picked up, a little here and a little there

\section{B03 (Neutral aimer, excerpt used in EA 6.2 and in Article 2)}

en mer ren form for engelsk, at jeg ikke har noe sånt dialekt-preget over det [...] på en måte, skal man finne den der mellomtingen

a cleaner form of English, that there isn't anything dialect-distinctive about it [...] you sort of have to find that thing in between 


\section{S06 (BrE aimer, excerpt used in EA 6.2 and in Article 1)}

[britisk engelsk] blir oppfattet som mer snobbete [...] mer borgerskapets språk [...] for å snakke britisk må man ha en viss holdning som kommer med aksenten, og den kan virke overlegen [...] overlegen som i utdannet, tenker jeg, og det har jeg ikke noe imot

[British English] is perceived as more posh [...] more upper class [...] to speak British one must have a certain attitude that can be interpreted as superior [...] but if that means superior as in educated, I don't mind

\section{S19 (BrE aimer, excerpt used in EA 6.3 and in Article 1)}

i klassen vår er det veldig mange mennesker som tar skolen veldig alvorlig, og de snakker britisk

In our class there are many people who take school very seriously, and these people speak British

\section{S21 (AmE aimer, excerpt used in EA 6.3 and in Article 1)}

jeg tror du blir oppfattet som [...] skoleflink hvis du snakker britisk

I think you are perceived as [...] a clever pupil if you speak British

\section{A06 (BrE aimer), A09 (BrE/AmE aimer) and A10 (BrE aimer), excerpt used in EA 6.4}

(Excerpt in the original only, see section 6.4 for translations)

A09 hvis du naturlig prøver å snakke engelsk da uten at du på en måte tenker veldig på hvordan hvilken talemåte du skal bruke, da heller det mer mot den amerikanske. Hvis du skal sitte i timen og imponere læreren litt så må du kanskje prøve å helle litt mer mot den engelske da britiske

A10 det har noe med hva jeg tror jeg trenger det til [...]

U så du tenker at du vil ha britisk fordi du skal bruke det...?

A10 i en jobbsammenheng

$\mathrm{U} \quad \mathrm{i}$ en jobbsammenheng. og da vil du helst ha det britiske?

A10 ja, veldig 
A10 hvis du er i utlandet hvis du er i ett område i England eller i USA, da begynner du jo selvfølgelig automatisk å snakke som de gjør

U hva hvis du er et sted som ikke er England eller USA? Spania...?

$[\ldots]$

A06 da hadde man snakket litt sånn norsk engelsk, litt sånn, ikke sånn veldig, men da hadde du ikke, du hadde ikke lagt an Oxford-aksenten hvis du er i Spania, da snakker du bare [...] da må du snakke litt sånn at de forstår det fordi de er ikke så veldig gode i engelsk, mange i utlandet, så da må du jo snakke litt sakte og liksom få de til å forstå

U så da ville dere ikke ha prøvd å snakke sånn som dere prøver å snakke i klasserommet?

A06 Nei

A09 Nei

A10 Nei, aldri

$[\ldots]$

A10 og så er det sånn at du prøver å snakke deg opp i timen og så kan det ofte hende at man snakker seg litt ned når man er i utlandet, hvis man ikke er i engelsktalende land

U opp...? hva tenker du på 'opp-ned'?

A10 nei, altså, penere da, prøve å snakke penere i timen, og heller faktisk med vilje snakke litt styggere når du er i utlandet

U for forståelsens skyld?

A10 ja

A09 og oppfattelsen

A10 og kanskje du blir litt snobbete hvis du snakker veldig sånn flytende engelsk

U hvorfor det?

A09 men alt dette miljøet igjen da. det kommer jo også igjen an på hvilket miljø du er i i det fremmede landet, for eksempel, altså hvis du sitter på en litt sånn slum ghetto bar så drar du ikke på den britiske aksenten din, det tror jeg ikke

$[\ldots]$

A09 og samtidig som, på den andre siden at du kanskje da sitter i et litt penere teselskap senere på dagen, da ville du kanskje endret littegrann på talemåten din da, skulle jeg tro

[latter $][\ldots]$

A10 nå kommer det: hvorfor det?

A09 fordi du vil jo ikke få juling

[latter] [...] 
U men hvorfor, ok, så dere høres snobbete ut, i noen miljøer vil dere ikke snakke britisk for da høres dere snobbete ut

A06 det er litt sånn, da vil det jo si hvem du snakker med også på en måte, eller hva slags miljø du er i, da. hvis du er i litt sånn, litt snobbete så er det jo den britiske

A09 man tilpasser seg omgivelsene rett og slett

A06 ja, det er jo det du gjør

\section{C02 (Neutral aimer, excerpt used in Articles 2 and 3)}

du uttaler det ut ifra det da, ut ifra hvordan det høres ut i hodet sånn naturlig, enn at du liksom skal forandre på det for å høres med britisk eller mer amerikansk ut. Det er rett og slett bare å lese og snakke sånn som du føler er naturlig for deg (School C)

you pronounce it based on how it sounds in your head, like, naturally, not that you, like, change it to sound more British or more American. It's actually just reading and talking the way that feels natural to you

\section{S21 (AmE aimer, excerpts used in Article 1)}

jeg har alltid vært sånn stor tilhenger av amerikansk, kanskje på grunn av at samtlige lærere jeg har hatt har snakket britisk engelsk, og jeg har vel ikke akkurat vært så veldig forkjyst i alle sammen

I have always been a fan of American, maybe because all the teachers I ever had have spoken British English, and I haven't really been very fond of them

den norske skole prøver å lære alle britisk engelsk fra starten av, men så er det mye enklere for elevene å lære amerikansk, for det er mye mer amerikansk TV og alt mulig sånn the Norwegian school tries to teach everyone British English from the beginning, but it's so much easier for the students to learn American, because there's much more American TV and stuff like that 


\section{S22 (AmE aimer, excerpts used in Article 1)}

Jeg liker England bedre, jeg vil heller dra dit enn til USA. Det er vel mer språket som er lettere for meg enn kulturen. [...] Det er vel sånn at jeg har blitt mer utsatt for amerikansk enn britisk

I like England better, I would rather go there than to the U.S. It is more the language that is easier for me, and not the culture [...] I guess I have been more exposed to American than British

man kan være minst like utdanna som man oppfatter britene, og fortsatt snakke med den amerikanske aksenten jeg har valgt, det er mer nord-øst

one can be at least as educated as one perceives the Brits and still speak the American accent I have chose, which is more North East

\section{S06 (BrE aimer, excerpt used in Article 1)}

jeg ville brukt amerikansk med ungdom og britisk med voksne [...] når vi er sammen med venner og sånn da skal vi ikke snakke den britisk-engelsken vi prøver å lære på skolen, da skal vi heller gjøre det vi synes er kult

I would use American with adolescents and British with grown-ups. [...] When we hang out with friends [...] we don't want to use the British English we try to learn at school, we would rather do what we think is cool 
APPENDIX 8: Individual production results for all participants in Data set 1 (DS1) and Data set 2 (DS2). Accent aim is given for each participant on the y-axis.

The production of Non-prevocalic / $r$ / in conversational speech for individual speakers (DS1)

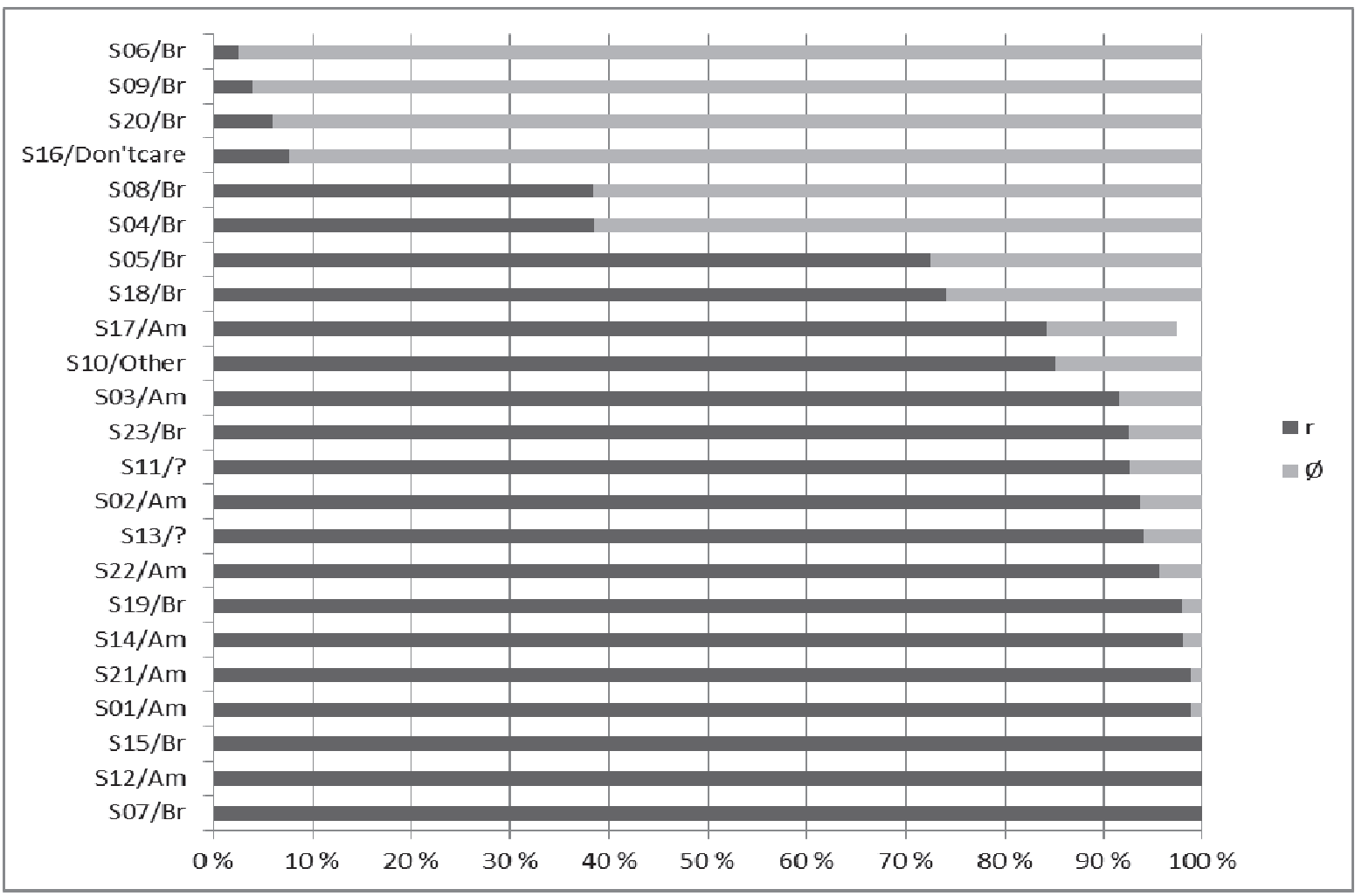

The production of Intervocalic / $t$ / in conversational speech for individual speakers (DS1)

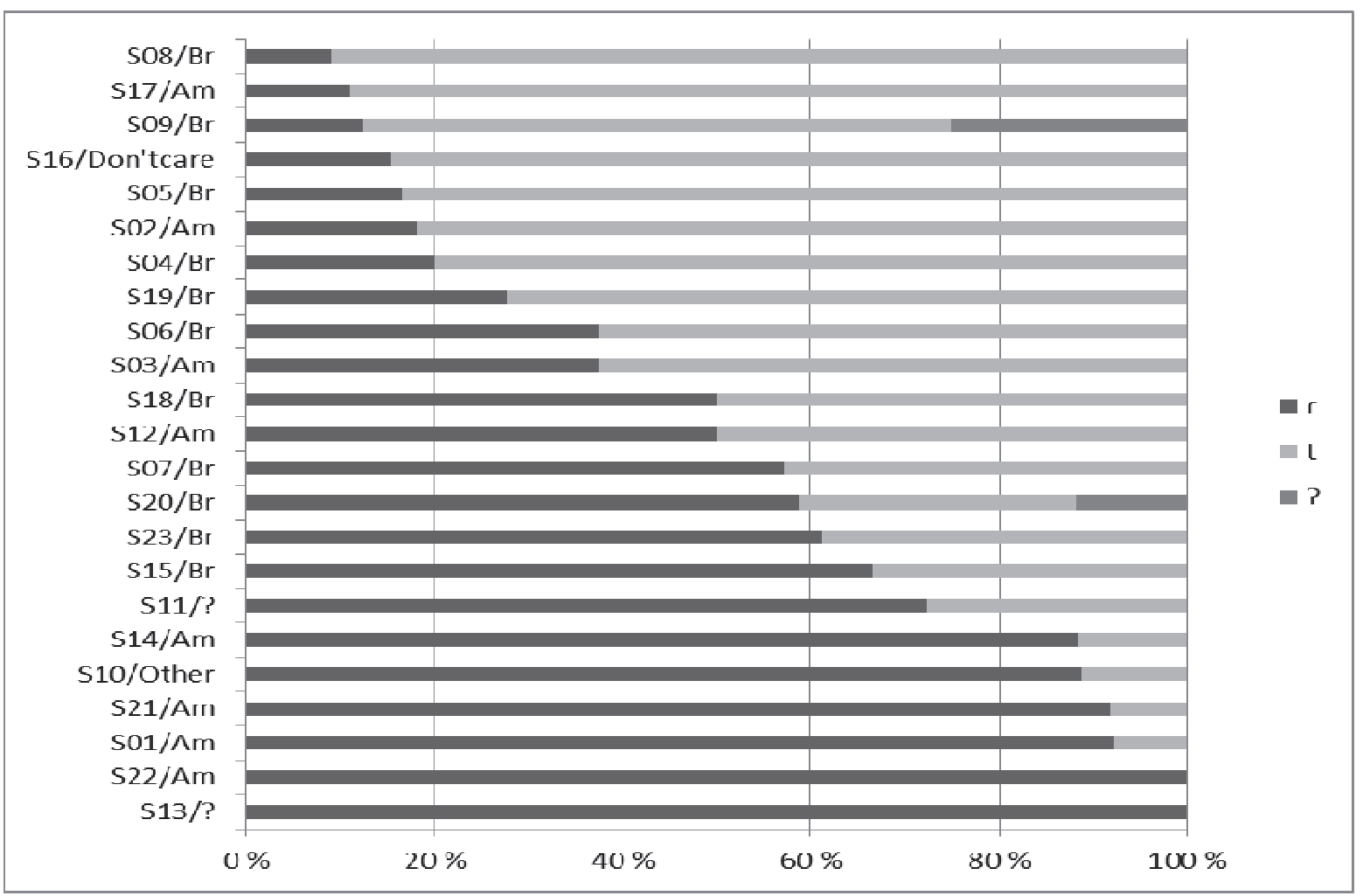


The production of GOAT in conversational speech for individual speakers (DS1)

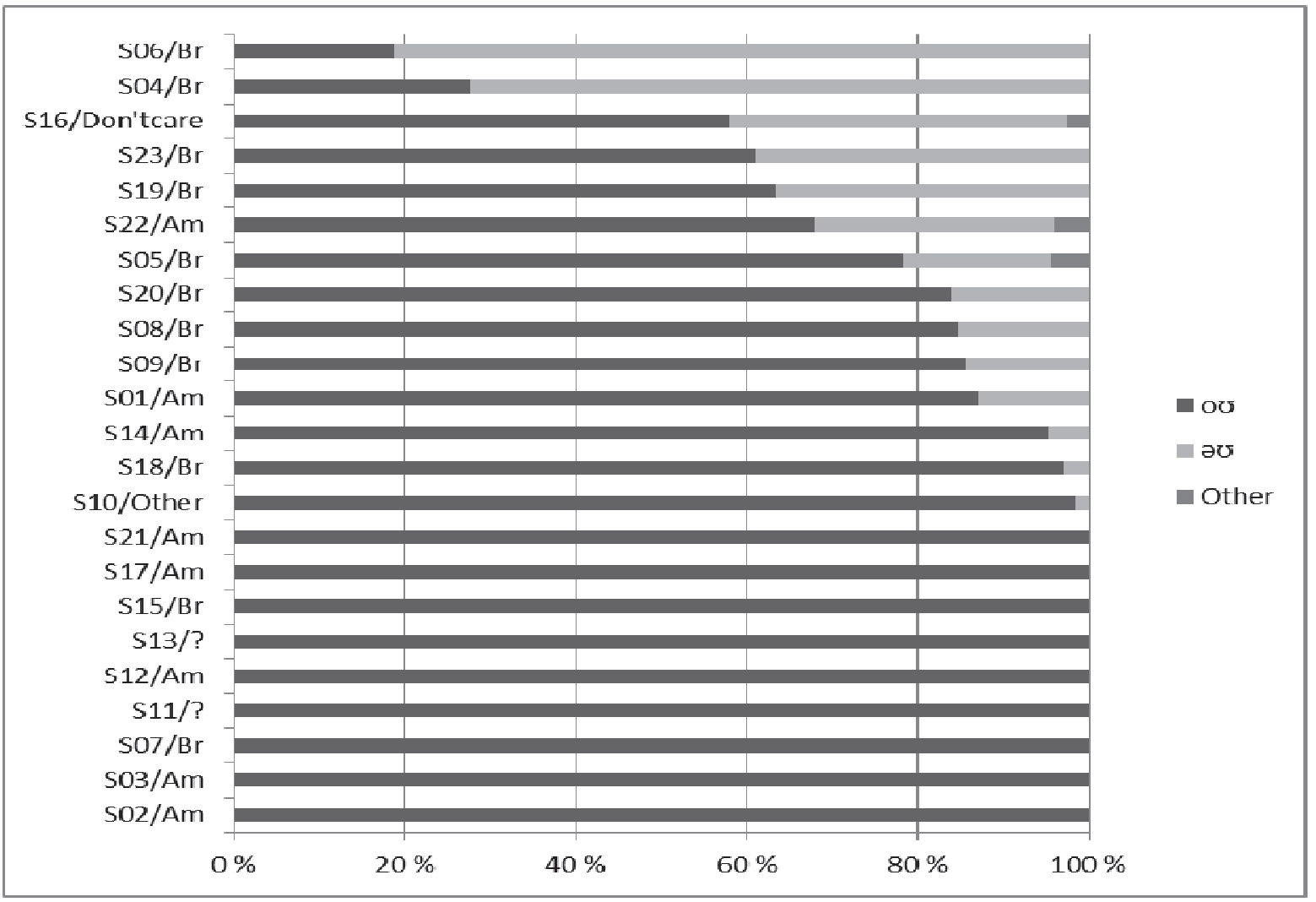

The production of LOT in conversational speech for individual speakers (DS1)

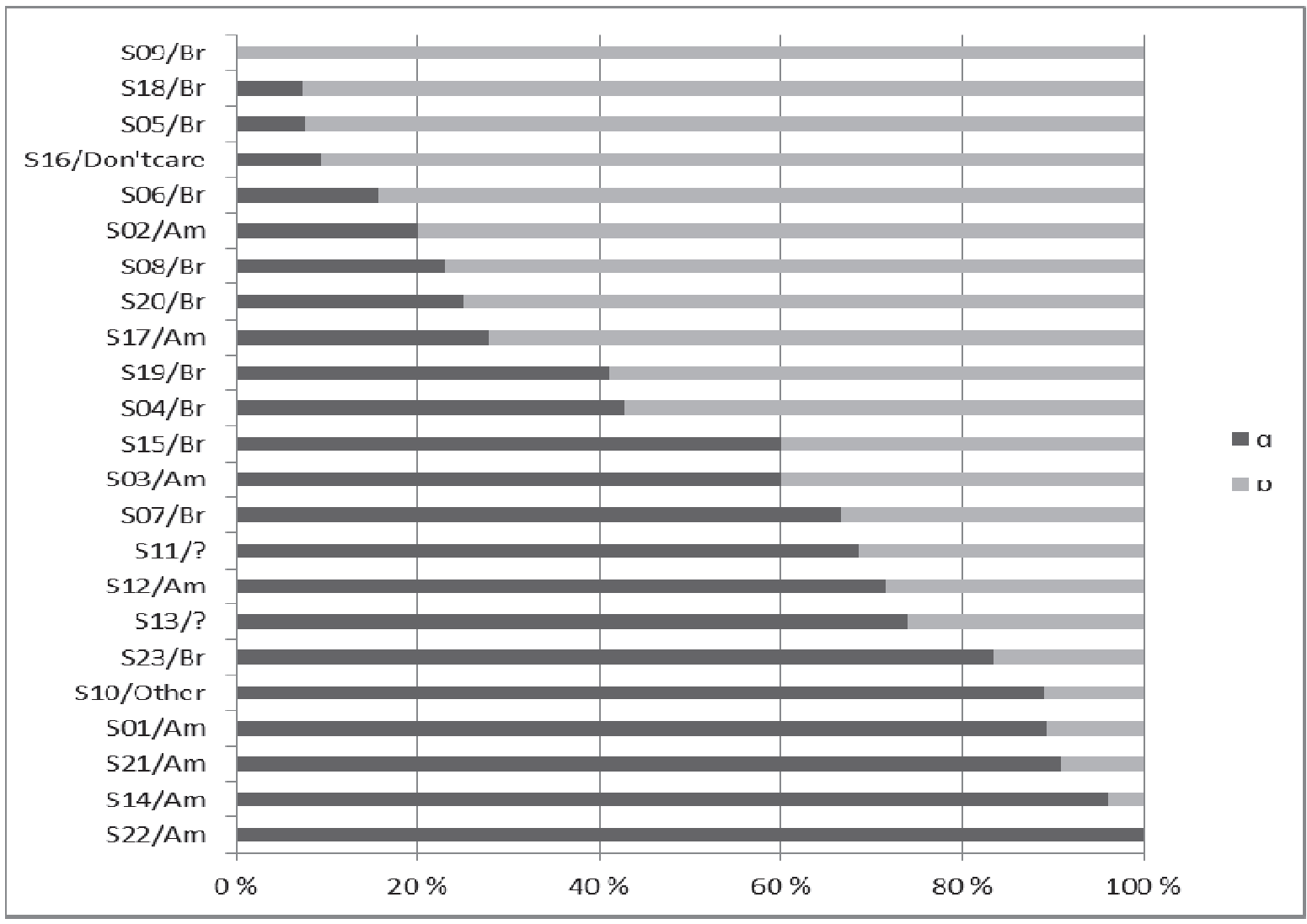


The production of BATH in conversational speech for individual speakers (DS2)

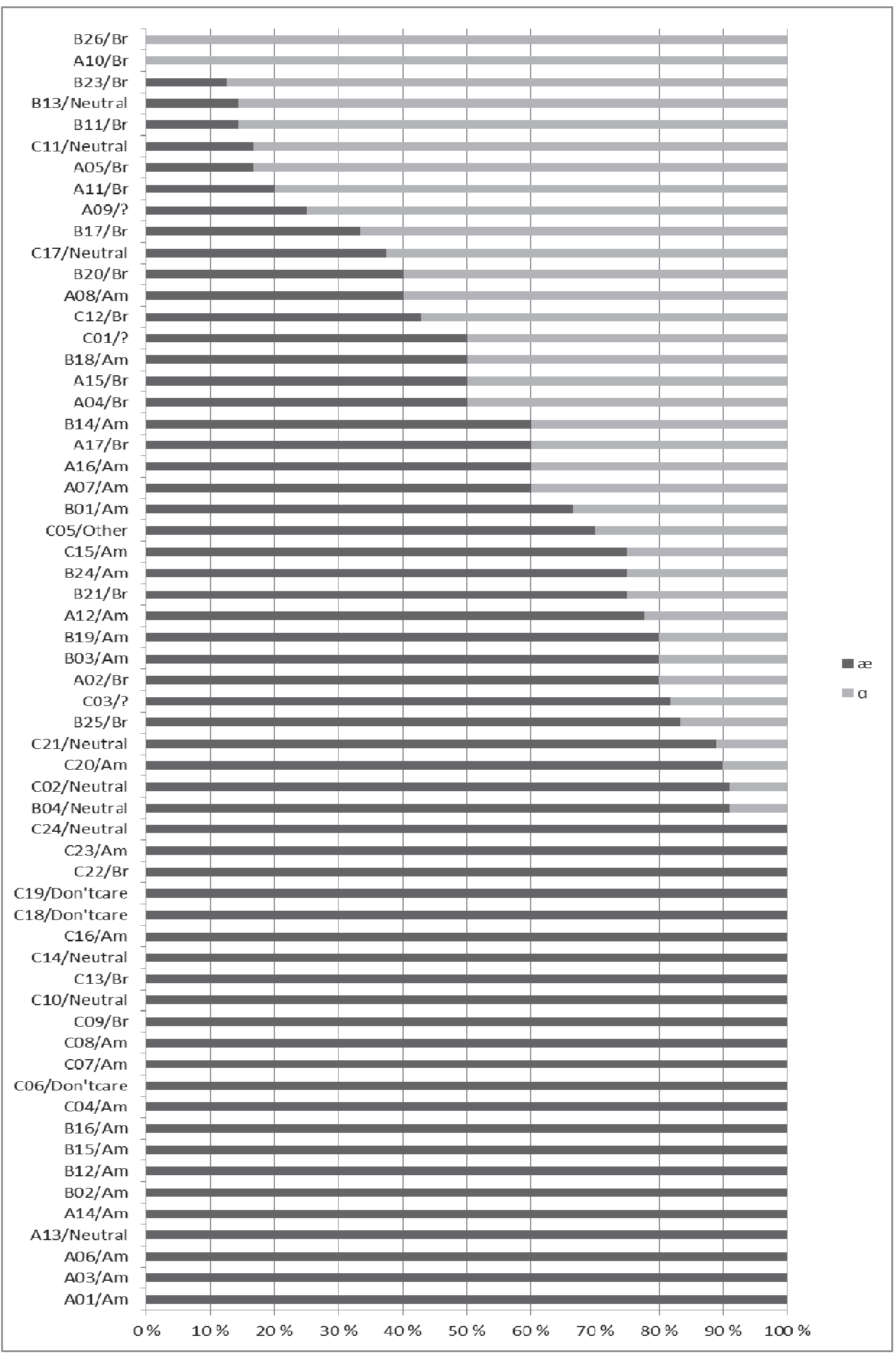


The production of Non-prevocalic/r/ in conversational speech for individual speakers (DS2)

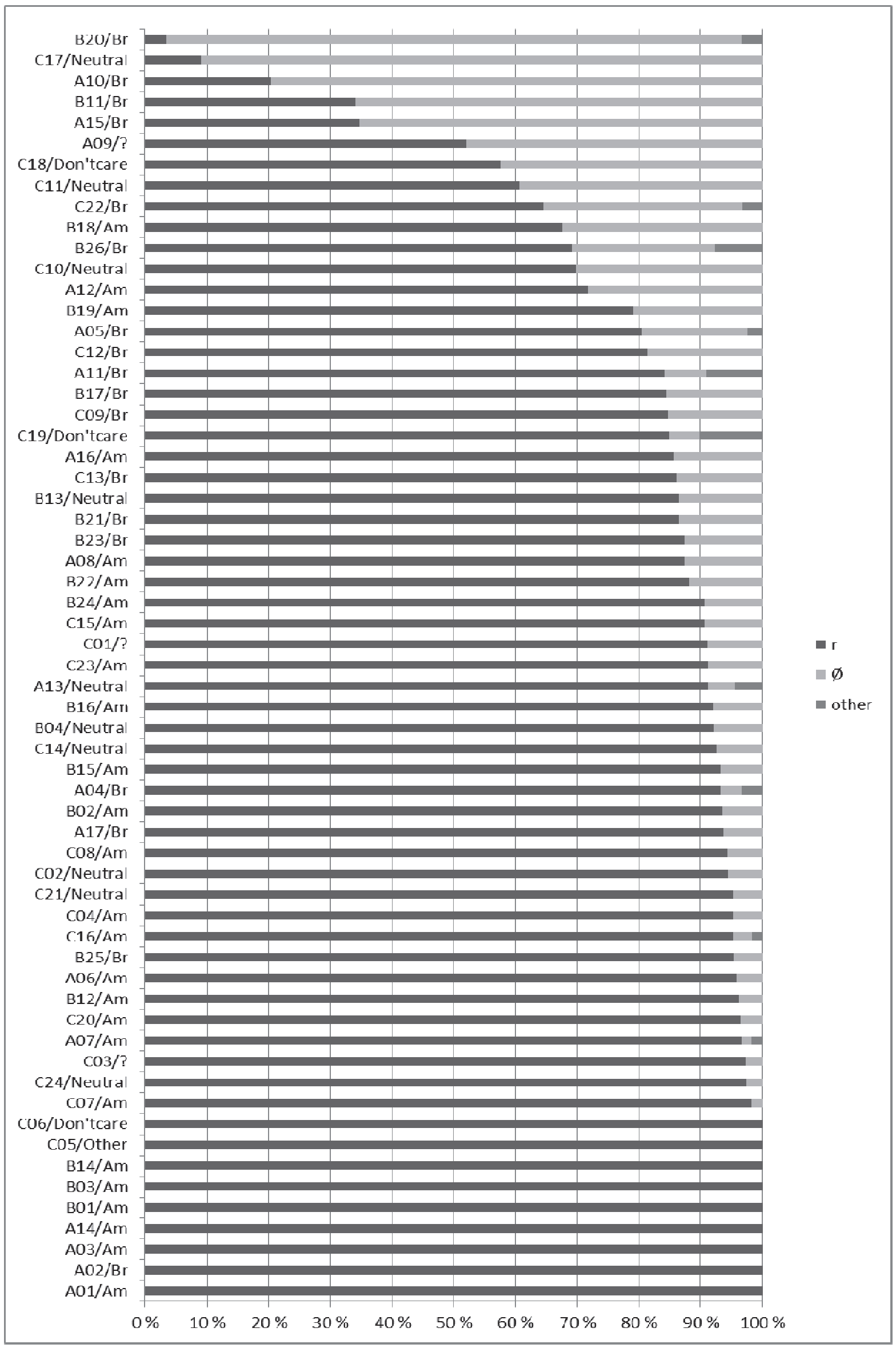


The production of Intervocalic / $t$ / in conversational speech for individual speakers (DS2)

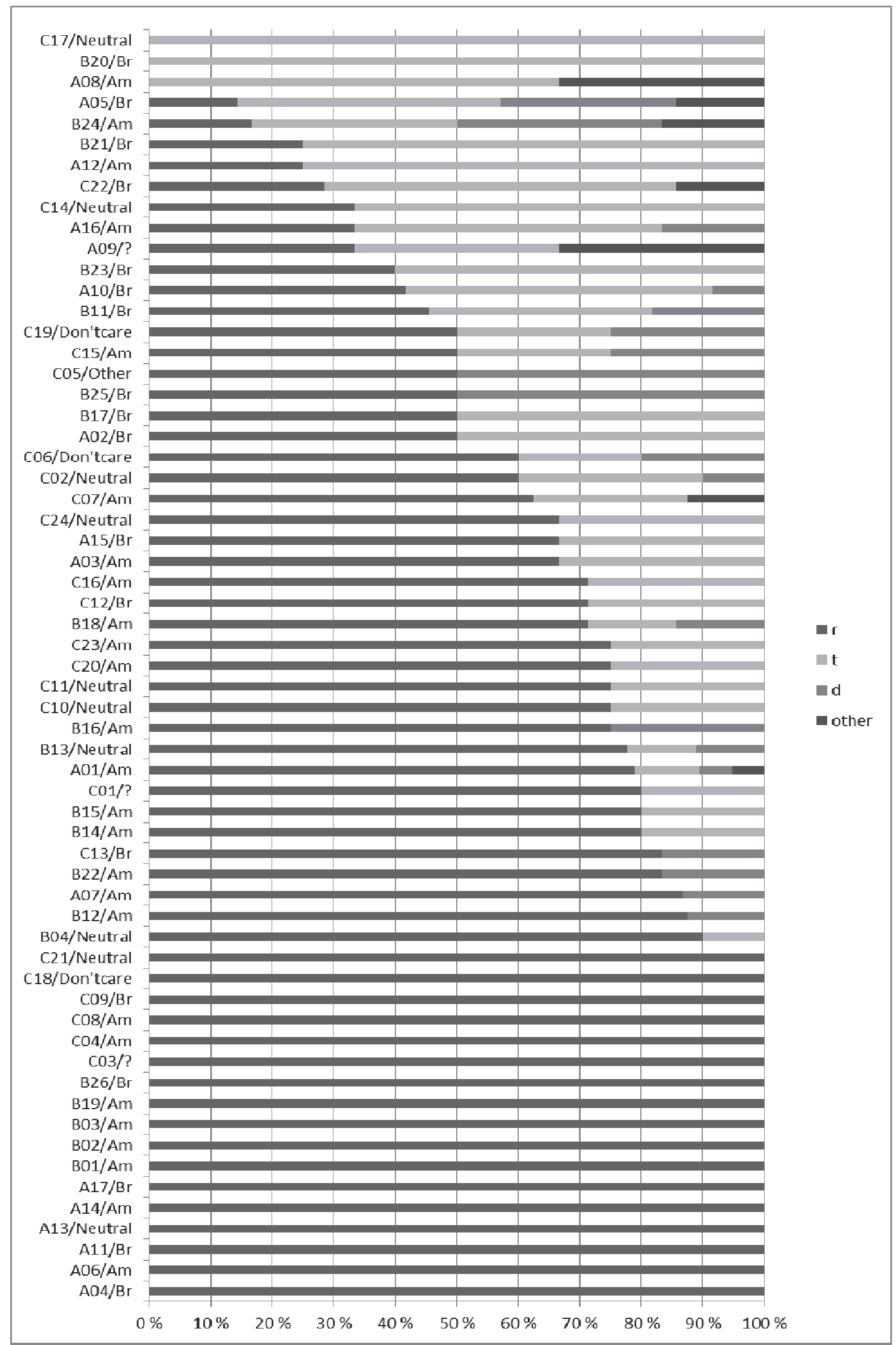


The production of LOT in conversational speech for individual speakers (DS2)

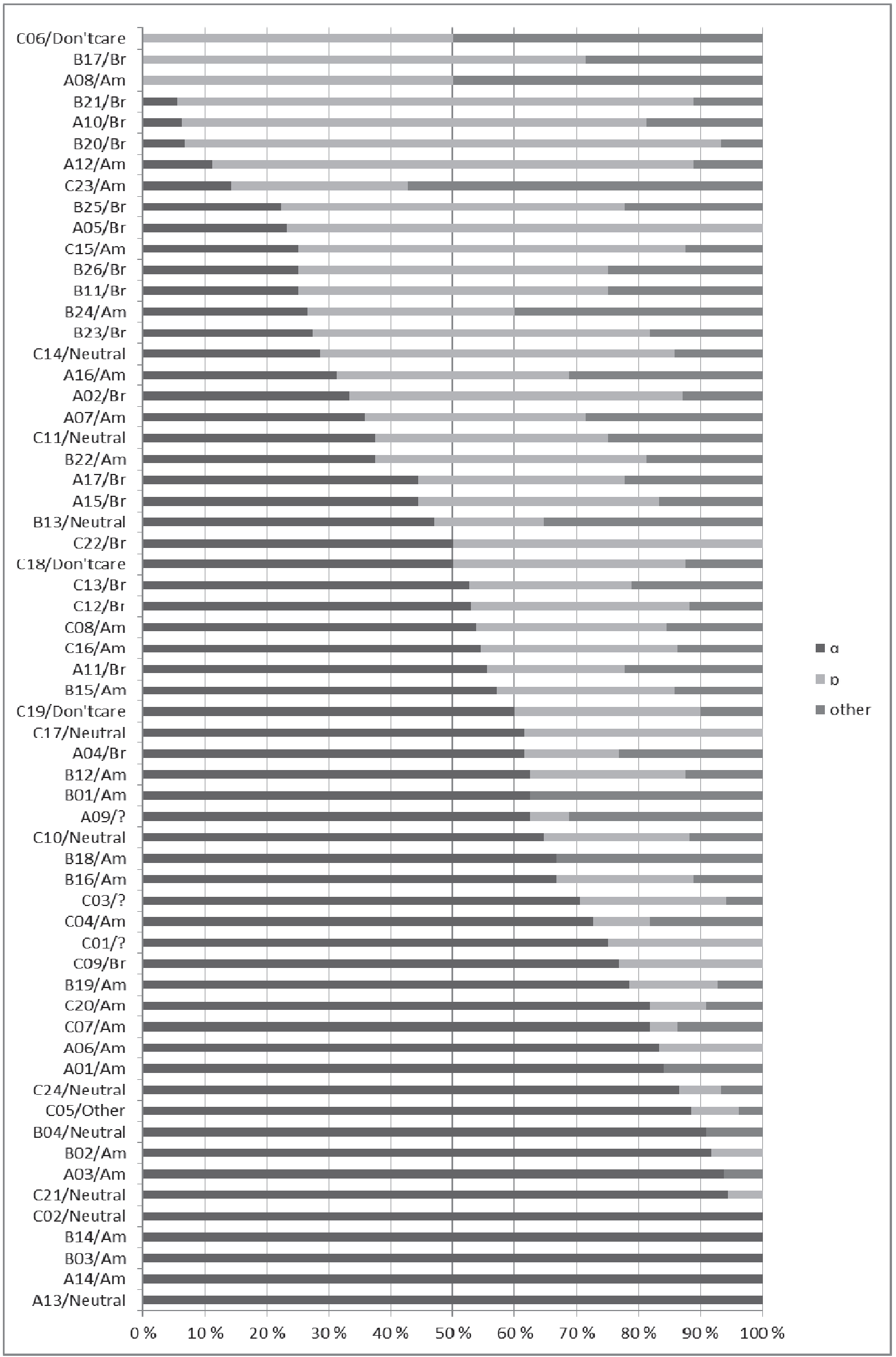


The production of Postcoronal / $\mathrm{j} /$ in conversational speech for individual speakers (DS2)

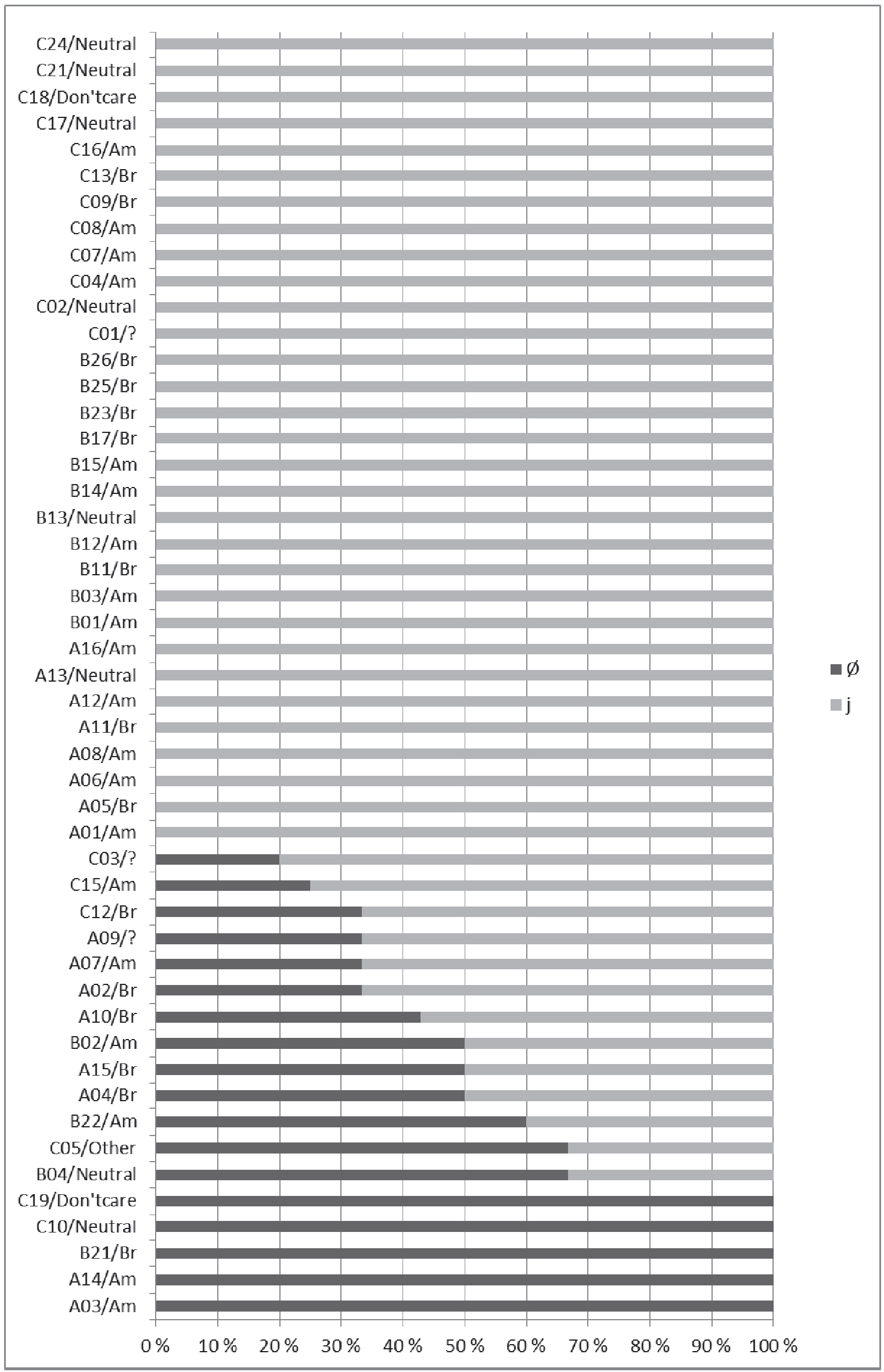


The production of Voiceless th in conversational speech for individual speakers (DS2)

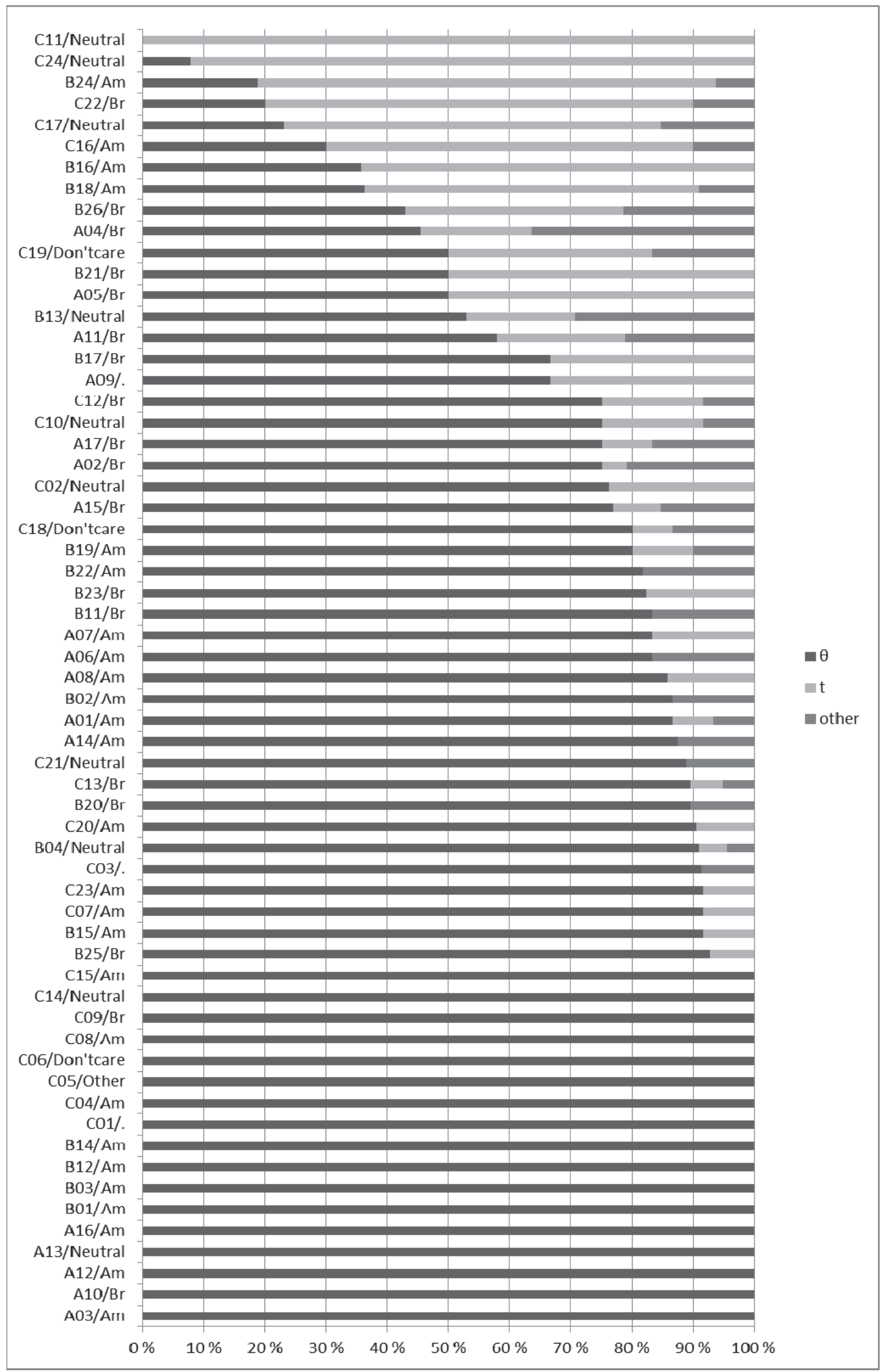


The production of GOAT in conversational speech for individual speakers (DS2)

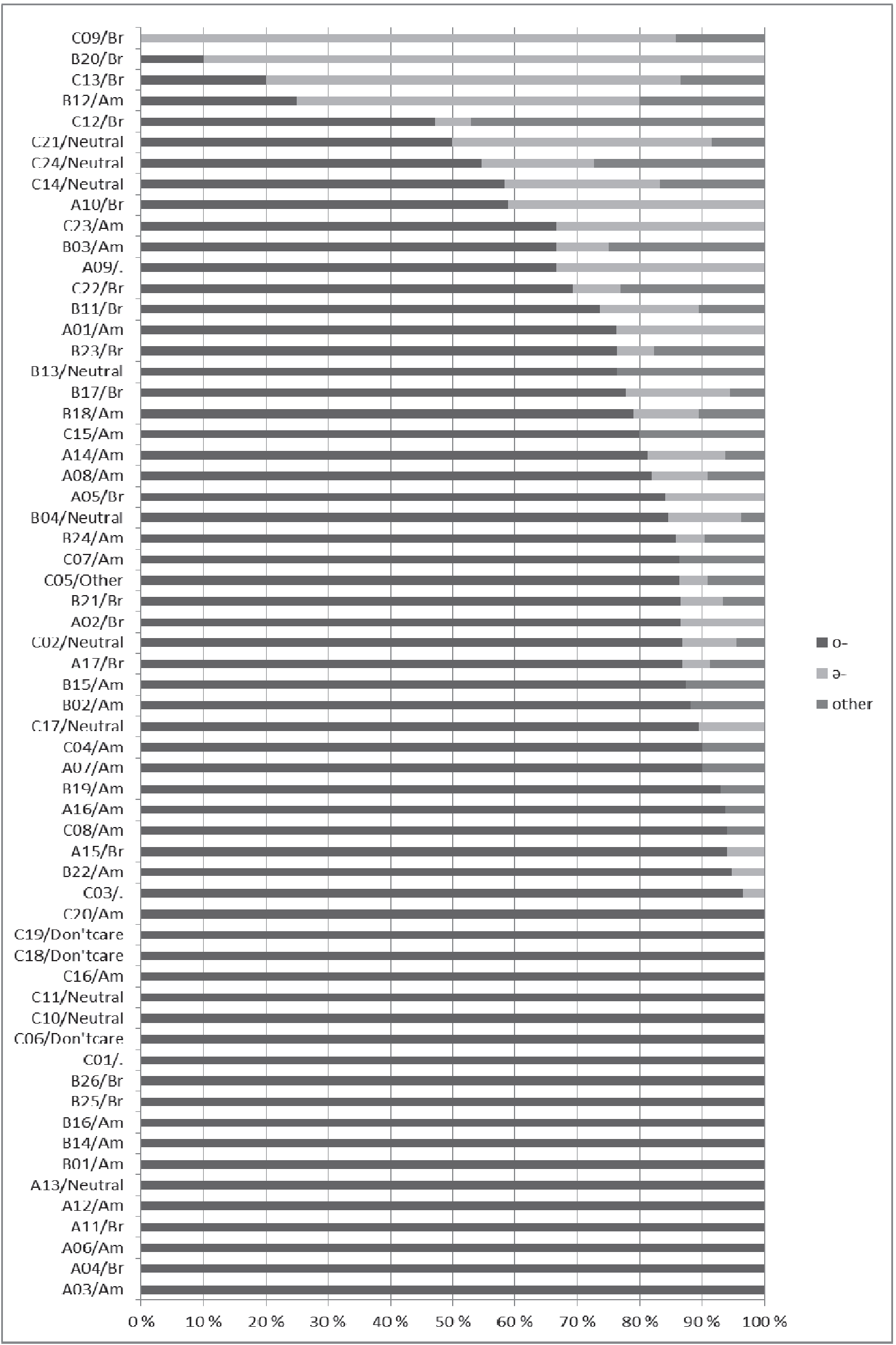




\title{
Article 2
}

\section{Learner attitudes and $L 2$ choices in Norway}

\begin{abstract}
This study investigates attitudes towards varieties of English among Norwegian adolescent learners, and assesses the role of social evaluation for L2 pronunciation choices. In an attempt to access the complexities of attitudes, a verbal guise test is combined with speaker commentary and reports of language choices. The results suggest that while American English is the most accessible English accent and the preferred L2 choice, Standard Southern British English remains the most prestigious English accent and retains the position as a formal English language teaching 'standard'. However, not all learners want to convey the social meanings attributed to these widely identified English varieties, and therefore aim towards a 'neutral' variety of English not associated with any native-English people or culture. These investigations into social motivations for L2 behaviour contribute to the ongoing discourse on the global spread and local appropriation of English, as well as to language attitude research in general. The results have implications for English language educators, who must meet the needs of proficient learners in an environment with increased intra-national use of English and no explicit model of pronunciation.
\end{abstract}

\section{INTRODUCTION}

Language carries social meaning; linguistic forms derive their meanings from language ideologies, and these can be accessed by investigating language attitudes. A central issue in language attitude research is therefore the relationship between attitudes and language behaviour (Garrett 2010). In a second language (L2) context, research on language attitudes can provide insight into language choices made by learners as well as into the status and development of the L2 in the given context. The present study investigates language attitudes towards varieties of English among Norwegian adolescents using a modified verbal-guise test combined with speaker commentary and reports of accent aims. With language attitudes as a backdrop, the article discusses the role of social evaluations for motivated choices and behaviour in the $\mathrm{L} 2$.

In Norway, English is widely used in lectures and readings in higher education, and is often used as lingua franca in large companies (Hellekjær, 2007; Ljosland, 2010). English is taught in school from year one (age six), it has a syllabus which distinguishes it from other foreign languages (Ministry of Education and Research, 2006), and it enjoys high status among learners (Bonnet, 2004). Adolescents have extensive access to a variety of linguistic 
resources through English-language television and films, travelling, and participation in social media (Johansson \& Graedler, 2002; Lund, 2006), and are relatively proficient learners of English (Education First, 2011). Because of considerable influence of American popular culture, most of the English-language media targeted towards adolescents is American English (Rindal, 2010).

Due to a national language policy that supports L1 diversity, there is strong public sense of language variation and the social meanings of variation, and relative tolerance towards variation in both written and spoken language (Røyneland, 2009; Sandøy, 2011). Standard ideology is not prominent; there is in fact no explicit standard spoken variety in the form of a determined socially accepted linguistic variety, and schools are by law obligated to allow students to use their local spoken varieties (Education Act § 2-5; Røyneland, 2009). In the same vein, there is no explicit model of English pronunciation in the English language syllabus either. Pronunciation criteria for English in the Norwegian national curriculum is accent-neutral, for instance "the pupil shall be able to express himself/herself in writing and orally with some precision, fluency and coherence" (Ministry of Education and Research, 2006). This means that practices and offered models of pronunciation among teachers of English are probably fairly diverse.

The Norwegian ELT context with proficient and language-aware learners allows for investigations into social evaluations of the L2. In line with the continuing internationalisation and globalisation of English, the investigation of attitudes towards varieties of English among L2 speakers can be of value to language education and teacher training in a country where English is increasingly used as part of speakers' identity repertoire (Rindal, 2010). With the Norwegian ELT setting as context, the present study addresses the following research questions:

1. What social evaluations do Norwegian learners make of English accents?

2. How do language attitudes relate to L2 choices?

The following subsections present previous research into attitudes towards English among L2 speakers, and discuss theoretical and methodological issues concerning language attitude research.

\section{Attitudes and learner models in non-native environments}

Researchers of language attitudes have established a set of primary evaluative dimensions on which speakers express attitudes towards speech or speakers, consisting of 'superiority' (e.g. 
educated, formal), 'attractiveness' (e.g. pleasant, attractive), and 'dynamism' (e.g. confident, interesting) (Garrett, 2010; Kristiansen, Garrett, \& Coupland, 2005). In some research, these dimensions have been condensed into two categories; 'competence' (or 'status') and 'social attractiveness' (or 'solidarity') (see e.g. Dalton-Puffer, Kaltenboeck, \& Smit, 1997; McKenzie, 2006; Preston, 2002). Among native speakers of English, so-called 'standard' varieties of English have been evaluated more positively on superiority dimensions than socalled 'non-standard' varieties, while the latter have been rated higher on dimensions of attractiveness (Coupland \& Bishop, 2007; Giles, 1970). Interestingly, in Denmark, the superiority and dynamism dimensions have been found to represent two different Danish 'standards' for young Danish speakers - a media standard and a school standard (Kristiansen, 2001).

In recent years an increasing number of studies have investigated attitudes of nonnative speakers towards varieties of English (e.g. Dalton-Puffer, et al., 1997; Evans \& Imai, 2011; Ladegaard, 1998; van der Haagen, 1998; Xu, Wang, \& Case, 2010). Among the nonnative speakers in European studies, Received Pronunciation (RP) or modern equivalents such as Standard Southern British English (henceforth SSBE) has been considered superior to both General American (GenAm) or 'standard' American English and so-called 'non-standard' varieties (Dalton-Puffer, et al., 1997; Jarvella, Bang, Jakobsen, \& Mees, 2001; Ladegaard, 1998; van der Haagen, 1998). In a Norwegian study, Rindal (2010) found that adolescents preferred SSBE over GenAm for status/competence and linguistic quality, while GenAm was considered more socially attractive.

Research in non-native contexts has also included a linguistic dimension to their methodology, and learners in Europe have considered SSBE the most attractive model of pronunciation (Ladegaard, 1998; Rindal, 2010; van der Haagen, 1998). However, scholars who engage in the discourse on the continuing internationalisation of English in a global context have come to question the role of native accents as learner models in English language teaching (e.g. Kachru, 1985; Phillipson, 1992). This criticism of native models in ELT has mostly concerned countries that are likely to have well-established internal models of English as alternatives to native accents, for instance post-colonial countries. In comparison, countries in which English is taught as a foreign language (EFL), including Norway, have traditionally looked to native accents for pronunciation models. However, also in the latter contexts, scholars have suggested avoiding the so-called 'standard' accents such as SSBE or GenAm as models for learners (e.g. Bex, 2008; Dalton-Puffer, et al., 1997; Dürmüller, 2008), because these accents are "imbued with the cultures of their origin", and 
following these norms might mean "implicitly signalling that they wish to convey the values of such native speakers" (Bex, 2008: 233). The 'standard' accents are, however, the most recognisable among non-native speakers; identification tests show that SSBE and GenAm are identified to a larger extent than varieties such as Australian English, Scottish English, or Cockney (Dalton-Puffer, et al., 1997; Jarvella, et al., 2001; Ladegaard, 1998). One can assume, therefore, that these accents are the most accessible to Norwegian learners.

\section{Theoretical considerations: attitudes}

In social psychology and sociolinguistics, attitude is generally given the status of a social psychological construct, and has naturally been a much debated concept. There is, however, some agreement about a tripartite structure of attitudes into the components cognition (beliefs about the social meaning of objects), affect (feelings about objects) and behaviour (predisposition to act consistently with cognitive and affective judgements) (Garrett, 2010; Kristiansen, et al., 2005). The affect component has more than one level; in addition to the evaluation given to e.g. a language variety, there is the stance towards this evaluation whether it is approved or disapproved of, for instance, and how important it is. Affect is in this way also related to choices and behaviour. However, the links between cognition and affect on the one hand, and behaviour on the other, is problematic. Positive affect towards certain speakers does not mean that one necessarily wishes to behave like them; "[a]ssociations between linguistic forms/styles and social meanings are therefore best seen as 'resources' available to speakers" (Kristiansen, et al., 2005: 18). Among proficient learners, social meanings related to English accents might function as resources in an L2 repertoire.

For the purposes of this study, attitude is defined as "a disposition to react favourably or unfavourably to a class of objects" (Sarnoff, 1970: 279). As mental constructs, attitudes are not directly observable, but must be inferred from more obvious processes, such as statements or behaviour. This study uses a modified verbal-guise test (VGT) to elicit such obvious processes, by asking the participants to rate speakers' levels of qualities or traits on semantic differential scales, such as 'how confident does this person sound'. Despite widespread application of such techniques in research on language attitudes, there are limitations and controversies which challenge their validity (see Garrett, 2010: 57-59 for an overview). The VGT, with its semantic scales, is reductionist and might miss the complexities of attitudes; therefore it might best be employed in combination with other sources of data (Kristiansen, et al., 2005). In the present study, evaluative reactions accessed with a VGT are therefore supported by more open-ended data from questionnaires and interviews. 


\section{The 'standard' and accents in the VGT}

The concept of a spoken 'Standard English' has been widely debated (e.g. Bex \& Watts, 1999; Milroy, 2007), and there is no general consensus about how to define it. Criteria often discussed in relation to a 'standard' is whether or not a variety is codified in dictionaries and grammars, whether the variety is developed in relation to a written variety, whether it is given supra-regional validity, and whether it functions as a norm ideal for a larger society (Auer, 2005). These characteristics have often been given to GenAm and SSBE, thus granting them authoritative and official status. A delimitation of 'Standard English' to SSBE and GenAm is relevant in EFL contexts, where the canonisation of these varieties are still widely employed (explicitly or implicitly) as models of pronunciation in English teaching (e.g. Locher \& Strässler, 2008). More generally, however, standard language can be understood as "an idealization - an idea in the mind rather than a fully achieved reality", and standard norms are related to a standard ideology; a "consciousness among speakers of a 'correct', or canonical, form of language" (Milroy, 2007: 134).

This study deals with the term 'standard' on two levels: first, 'standard' American English and 'standard' British English are viewed as GenAm and SSBE, as defined by e.g. Wells (1982) and the International Phonetic Association (1999). The stimulus chosen for the VGT were speakers of these varieties. Speakers from Scotland and Leeds were included to investigate attitudes towards varieties that traditionally are considered 'non-standard' as models in non-native environments, and to divert focus from the so-called 'standard' English varieties. On a second level, 'standard' refers in this study to the ideological value given to varieties of English in Norway. In line with this understanding of 'standard', the VGT attempts to elicit participants' social evaluations of the accents and investigate whether there is an idea of a 'correct' or 'canonical' form of English in this L2 context.

\section{PARTICIPANTS AND PROCEDURE}

The participants of the study ( $\mathrm{N}=70,40$ females and 30 males) were 17 years old and in their second year of upper secondary school. They were students in three different classes from three different schools and had studied English for 11 years. $90 \%$ of the participants reported having attended Norwegian school from year 1, which means that most of them would have learnt English in the Norwegian school system and in the Norwegian society.

A modified verbal-guise test was used to investigate participants' reactions to different English varieties. The verbal-guise technique is a derivative of the matched-guise technique, 
(Lambert, Hodgson, Gardner, \& Fillenbaum, 1960), where recordings of two or more varieties produced by a single speaker is evaluated by listeners who are under the impression that they are listening to different speakers, thus allowing for evaluation of accents when individual voice attributes are the same. Initially, the stimulus speakers in this study all produced two voices as part of a matched-guise design, and were then assessed for accent and mimicking authenticity: all voices were prior to the test played to professional linguists (a native speaker of British English, a native speaker of American English, and a non-native speaker of English), as well as to a pilot group of four Norwegian adolescents. Any voices which were reported to sound non-authentic, non-native or just 'strange' by any of these assessors were removed from the stimulus recordings, leaving only two matched-guise voices which were judged to be authentic by all assessors. A basic verbal-guise design with separate speakers for each variety gives more accurate representations of accents, but this increases the possibility for evaluations being made due to other features than accent, and therefore the two matchedguise voices were included in the test, alongside the verbal-guise voices. The final stimulus comprised nine speakers producing 11 voices; two female and two male SSBE voices, two female and two male GenAm voices, one female and one male Scottish English voice, and one female Leeds English voice. The speakers, all but one professional linguists with postgraduate degrees (Voice 10 was a proof reader with a university degree within Humanities), were recorded while reading The North Wind and the Sun. Recordings were screened for reading rate and obvious differences in reading animation. Table 1 gives an overview of the voices in the order they were played to the participants, in addition to the speakers' own accent descriptions.

After each recording in the stimulus, the participants were asked to fill out evaluation forms with 16 semantically labelled scales. The scales were chosen from those employed in previous and comparable studies (e.g. Ladegaard, 1998; Rindal, 2010; van der Haagen, 1998), but were moderated and supplemented after pilot tests and conversations with comparable raters. The participants were asked to evaluate 13 person-related qualities (interesting, confident, urban, ambitious, pleasant, educated, modern, formal, attractive, intelligent, reliable, cool, authority) and three language-related qualities (intelligible, aesthetic, model of pronunciation) on scales from 1 (low) to 5 (high), reporting their first impression. The instructions and scales given in the original evaluation form are presented with English translations in Appendix 1.

Following the VGT, the stimulus recordings were replayed to the participants in a different order and the participants were asked to identify the origin of the speakers - USA, 
England or Other country - in a questionnaire. Prior to this identification test, the school classes discussed briefly with their English teacher the notions of UK, Great Britain and England, in order to ensure concept agreement. The participants were informed that all stimulus speakers were native speakers of English, but that not all English-speaking countries were represented, and that the represented countries were not necessarily evenly distributed in the test. The participants were asked to specify the Other country alternative. The results of this test are displayed in Table 1.

Table 1. Speakers in the VGT, with bio and description of accent

\begin{tabular}{|c|c|c|c|c|}
\hline & Voice & Bio & Accent & ID $\%$ \\
\hline 1 & SSBE/M1 & Male (41) from Derby, England & $R P$ & 86 \\
\hline 2 & GenAm/F1 & Female (39) from Indiana, USA & Midwestern & 89 \\
\hline 3 & GenAm/M1 & $\begin{array}{l}\text { Male (32) (= SSBE/M2), from New } \\
\text { Hampshire/Massachusetts, USA }\end{array}$ & $\begin{array}{l}\text { Fairly standard } \\
\text { American accent }\end{array}$ & 93 \\
\hline 4 & $\mathrm{ScE} / \mathrm{M}$ & Male (39) from Edinburgh, Scotland & $\begin{array}{l}\text { Scottish Standard } \\
\text { English }\end{array}$ & 21 \\
\hline 5 & $\mathrm{SSBE} / \mathrm{F} 1$ & $\begin{array}{l}\text { Female }(32)(=\mathrm{ScE} / \mathrm{F}) \text { from } \\
\text { Aberdeen/Sterling, Scotland }\end{array}$ & $R P$ & 84 \\
\hline 6 & GenAm/M2 & Male (39) from DC/Maryland, USA & $\begin{array}{l}\text { Pretty standard } \\
\text { American }\end{array}$ & 77 \\
\hline 7 & Leeds/F & Female (27) from Leeds, England & Leeds accent & 37 \\
\hline 8 & $\mathrm{SSBE} / \mathrm{F} 2$ & $\begin{array}{l}\text { Female (42) from Birmingham, } \\
\text { England }\end{array}$ & $\begin{array}{l}\text { Southern Standard } \\
\text { British English }\end{array}$ & 79 \\
\hline 9 & $\mathrm{SSBE} / \mathrm{M} 2$ & $\begin{array}{l}\text { Male (32) (= GenAm/M1), from New } \\
\text { Hampshire/Massachusetts, USA }\end{array}$ & $R P$ & 56 \\
\hline 10 & GenAm/F2 & $\begin{array}{l}\text { Female (44) from Illinois/New } \\
\text { Jersey, USA }\end{array}$ & $\begin{array}{l}\text { North East American, } \\
\text { [like] on } T V\end{array}$ & 93 \\
\hline 11 & $\mathrm{ScE} / \mathrm{F}$ & $\begin{array}{l}\text { Female }(32)(=\mathrm{SSBE} / \mathrm{F} 1) \text { from } \\
\text { Aberdeen/Sterling, Scotland }\end{array}$ & $\begin{array}{l}\text { Standard Scottish with } \\
\text { some North East } \\
\text { features }\end{array}$ & 46 \\
\hline
\end{tabular}

Note: Percentage of correct identification of accent by participants in the identification test. Voices 3 and 9 are produced by the same speaker, as are Voices 5 and 11 .

\section{RESULTS}

\section{Identification of English accents}

Table 1 gives the percentage of correct identification of the accent origins in the VGT (or intended origin, in the case of the matched-guise voices). The identification of SSBE and GenAm was high overall; between 77 and 93 percent of the participants identified the origin of these accents correctly. Even the origin of the female SSBE matched-guise SSBE/F1 
(Voice 5) was identified as 'England' by 84 percent of the participants. Only one participant answered "Scotland?" as supposed origin of this accent, which is in fact the speaker's actual geographical origin. The one exception to the identification rate of SSBE and GenAm voices was the male SSBE matched-guise voice SSBE/M2 (Voice 9) whom only 56 percent identified as originating from 'England', even though the voice had been assessed repeatedly for accent authenticity in advance. 29 percent of the participants guessed that the speaker originated in the USA, while 13 percent guessed other origins. Although there was uncertainty about the identification of one of the matched-guise voices, this voice was evaluated similarly to the other male GenAm voice as intended by the test design (cf. Methodological limitations below), which justifies its inclusion.

As in previous research on accent identification, the origins of the Scottish and Leeds accents were not identified as widely as were the SSBE and GenAm accents. Only 46, 21, and 37 percent gave correct identification of the origin of the female $\mathrm{ScE}$ accent, the male $\mathrm{ScE}$ accent and the Leeds accent, respectively. The participants were unsure whether the Scottish and Leeds speakers originated in Scotland, Ireland or England. The Leeds speaker was in addition mistaken for Welsh or Australian. There is a disparity, then, between the overall correct identification of so-called 'standard' accents and the identification uncertainty regarding so-called 'non-standard' accents. This identification pattern is not, however, reflected in the evaluational reactions to the speakers in the VGT, which are presented in the following section.

\section{Attitudes towards English accents}

In order to investigate whether the Norwegian learner attitudes pattern into distinct evaluative dimensions as suggested by previous research, a principal components analysis (PCA) with Varimax rotation was performed on the ratings given to each individual quality on the evaluation form. Three components with Eigenvalues greater than one were retained, which together accounted for two thirds of the variance. Table 2 presents the component loadings, where all the qualities except two loaded 0.6 or above on one of the three components. Component 1 consists of qualities related to status and competence, while the qualities in Component 2 can best be described as attributes of social attractiveness. Component 3 holds the traits related to the linguistic quality of the accents. ${ }^{1}$ The qualities confident and urban were not loaded on any specific component; these are excluded from the analysis of the dimensions below. 
Table 2. Loadings of qualities onto principal components

\begin{tabular}{|l|c|cc|}
\hline \multirow{2}{*}{ Educated } & \multicolumn{3}{|c|}{ Component } \\
Formal & 1 & 2 & 3 \\
\hline Intelligent & .869 & .097 & .266 \\
Authority & .790 & .184 & .095 \\
Reliable & .773 & .239 & .295 \\
Ambitious & .720 & .315 & .250 \\
& .677 & .449 & .063 \\
Modern & .666 & .367 & .284 \\
Cool & \multicolumn{3}{|c}{} \\
Interesting & .225 & .776 & .095 \\
Attractive & .290 & .729 & .084 \\
Pleasant & .018 & .705 & .306 \\
& .371 & .657 & .131 \\
Model & .458 & .613 & .165 \\
Intelligible & \multicolumn{3}{|c}{} \\
Aesthetic & .216 & .077 & .859 \\
& .208 & .119 & .805 \\
Confident & .177 & .273 & .803 \\
Urban & \multicolumn{3}{|c}{} \\
\cline { 2 - 3 } & .408 & .433 & .469 \\
& .451 & .396 & .367 \\
\hline
\end{tabular}

Following the PCA, new variables were computed by combining the qualities within the three components revealed by the PCA, thus forming three evaluative dimensions: STATUS And Competence, Social AtTRACTIVEness and Linguistic Quality. The 11 stimulus voices were grouped into four accents based on self-characterisation (cf. Table 1), confirmed by the author and assessors: Standard Southern British English (SSBE), General American (GenAm), Scottish English (ScE) and Leeds English (Leeds). This categorisation was supported by the listener evaluations (cf. Methodological limitations below). A one-way repeated measures analysis of variance (ANOVA with Bonferroni-adjusted post-hoc comparisons) was conducted to compare the evaluations of the accents. The ranking of the accents for the three dimensions is given in Table 3, with mean evaluation scores (out of a total of 5) and standard deviations. All standard deviations have been averaged from those of the individual speakers in the group. The results show that the SSBE speakers are rated higher for all three evaluative dimensions. In contrast to the identification test results where GenAm and SSBE were correctly identified to a large extent while the so-called 'non-standards' were not, the evaluative reactions to GenAm in the VGT pattern similarly to those of ScE and 
Leeds. While the difference between SSBE and the other accents are significant for STATUS AND COMPETENCE and LingUisTiC QUALITY, this is not the case for Social ATTRACTIVENESS, where there is less variation between the accents.

Table 3. Mean accent evaluation scores for the three PCA components, with overall ANOVA and post-hoc results

\begin{tabular}{|c|c|c|c|c|c|}
\hline \multicolumn{2}{|c|}{ StATUS \& } & \multicolumn{2}{|l|}{ SOCIAL } & \multicolumn{2}{|c|}{ LINGUISTIC } \\
\hline \multicolumn{2}{|c|}{ COMPETENCE } & \multicolumn{2}{|c|}{ ATTRACTIVENESS } & \multicolumn{2}{|c|}{ QUALITY } \\
\hline \multicolumn{2}{|c|}{$\mathrm{F}(3,276)=34.39, \mathrm{p}<0.001$} & \multicolumn{2}{|c|}{$\mathrm{F}(3,276)=8.53, \mathrm{p}<0.001$} & \multicolumn{2}{|c|}{$\mathrm{F}(3,276)=29.03, \mathrm{p}<0.001$} \\
\hline SSBE & $3.86(0.65)$ & SSBE & $3.40(0.67)$ & SSBE & $4.40(0.57)$ \\
\hline $\mathrm{ScE}$ & $3.11(0.70)$ & GenAm & $3.18(0.78)$ & GenAm & $3.73(0.81)$ \\
\hline GenAm & $3.06(0.68)$ & $\mathrm{ScE}$ & $3.04(0.74)$ & $\mathrm{ScE}$ & $3.46(0.98)$ \\
\hline Leeds & $2.98(0.73)$ & Leeds & $2.92(0.75)$ & Leeds & $3.43(0.80)$ \\
\hline
\end{tabular}

Note: Standard deviations in parenthesis. The presence of a line denotes a significant difference between the evaluations of all accent groups above the line and all accent groups below the line; single line $=p<0.05$, bold line $=p<0.01$, double line $=p<0.001$.

The accent groups were categorised further by gender, and ANOVAs were conducted to compare mean evaluations of the accent/gender groups. Since there was only one Leeds English speaker, this speaker is omitted from the analysis. The ranking of the accent/gender groups for the three PCA dimensions is given in Table 4, with mean scores and standard deviations. Appendix 2 gives an overview of the mean scores for the accent/gender groups for all individual qualities.

Table 4. Mean evaluation scores for the three PCA dimensions by accent and gender, with overall ANOVA and post-hoc results

\begin{tabular}{|c|c|c|c|c|c|}
\hline \multicolumn{2}{|l|}{ STATUS \& } & \multicolumn{2}{|l|}{ SOCIAL } & \multicolumn{2}{|c|}{ LINGUISTIC } \\
\hline \multicolumn{2}{|c|}{ COMPETENCE } & \multicolumn{2}{|c|}{ ATTRACTIVENESS } & \multicolumn{2}{|l|}{ QUALITY } \\
\hline \multicolumn{2}{|c|}{$\mathrm{F}(5,414)=38.19, \mathrm{p}<0.001$} & \multicolumn{2}{|c|}{$\mathrm{F}(5,414)=14.15, \mathrm{p}<0.001$} & \multicolumn{2}{|c|}{$F(5,414)=27.92, p<0.001$} \\
\hline SSBE F & $4.13(0.57)$ & SSBE F & $3.76(0.62)$ & SSBE F & $4.67(0.42)$ \\
\hline SSBE M & $3.59(0.74)$ & GenAm M & $3.28(0.70)$ & SSBE M & $4.14(0.72)$ \\
\hline GenAm M & $3.22(0.61)$ & ScE F & $3.079(0.77)$ & GenAm M & $3.78(0.86)$ \\
\hline $\mathrm{ScE} \mathrm{M}$ & $3.15(0.66)$ & GenAm F & $3.075(0.86)$ & GenAm F & $3.68(0.76)$ \\
\hline ScE F & $3.08(0.74)$ & SSBE M & $3.04(0.72)$ & ScE M & $3.49(0.99)$ \\
\hline GenAm F & $2.90(0.75)$ & ScE M & $3.00(0.72)$ & ScE F & $3.44(0.97)$ \\
\hline
\end{tabular}

Note: $\mathrm{F}=$ Female, $\mathrm{M}=$ Male. Standard deviations in parenthesis. The presence of a line denotes a significant difference; $\underline{\text { single line }=p<0.05}$, $\underline{\text { bold line }=p<0.01}$, double line $=p<0.001$. 
The gender categorisation shows that the female SSBE voices are rated significantly higher than all other groups, including the male SSBE voices, for all dimensions. In fact, for the Social AtTRACTIVENESS dimension, the male SSBE voices are evaluated similarly to the ScE voices, and slightly below the GenAm voices; the female speakers are the reason for the SSBE preference for Social AtTRACTIVEnEss (cf. Table 3). The 'standard' British accent, then, is distinguished from the other accents to a large extent when produced by female speakers.

The components revealed by the PCA are consistent with the evaluative dimensions found in previous language attitude research, especially in non-native environments (e.g. Dalton-Puffer, et al., 1997; McKenzie, 2006; van der Haagen, 1998). In order to further validate the attitude results, and present a more detailed and complex picture of language attitudes in the L2 environment, the VGT is combined with questionnaire and interview data.

\section{English accent aims}

In a questionnaire, the participants provided background information about gender, home language and accent aim. ANOVAs or t-tests were conducted with these, in addition to school, as independent variables to investigate the effect on any part of the participant evaluations, either on voices and qualities separately or combined into accent/gender groups and evaluative dimensions. The results of the analysis showed that school, gender, home language and accent aim had few (and apparently random) significant effects on accent evaluation.

The participants were also asked to report which accent they aimed towards when they spoke English; British, American, Norwegian, 'Neutral', Other, or I don't care. It was important that the labels presented in the questionnaire were familiar to the participants. Pilot studies suggested that American used by Norwegians generally refers to a GenAm accent, and British generally refers to an SSBE accent. The low identification rate for the Leeds and ScE voices in the identification test supports this assumption. The option Norwegian English is commonly used in the media and among the public to refer to English with Norwegian L1 influence, and accents with very distinct L1 influence are by some teachers nicknamed 'NoEnglish' and ridiculed in the media (e.g. Herseth, 2009). 'Neutral' was given as an alternative in the questionnaire following pilot studies and conversations with speakers of the same age, who reported that they did not aim towards any of the well-known native accents such as American English or British English, but rather a 'neutral' English accent. The label was thus expected to be familiar to adolescent learners, but was given in inverted commas as it is not 
commonly used in writing. The fieldworker was present during the administration of the questionnaire, and the participants did not present any doubts concerning the questionnaire alternatives. Following the administration of the VGT and the questionnaire, a focus-group interview was held at each school, and interviewees were asked to define 'neutral' English. There seemed to be agreement across interviewees and across schools that 'neutral' meant speaking the L2 without any identifiable native accent. Below are definitions of 'neutral' given by interviewees in the three different schools. Interviews were held in Norwegian and quotes are translated into English by the author.

engelsk uten noe sånt spesifikt tonefall mot noen aksent (School A) English without any sort of specific tone of voice towards any accent

en mer ren form for engelsk, at jeg ikke har noe sånt dialekt-preget over det [...] uten, på en måte, noe spesielle måter å uttale ordene på [...] vi kan, på en måte, snakke hva vi synes er mest behagelig da, men som oftest så, på en måte, skal man finne den der mellomtingen (School B)

a cleaner form of English, that there isn't anything dialect-distinctive about it [...] without any special ways to pronounce the words [...] we can sort of speak the way we think is most comfortable, but most of the time you sort of have to find that thing in between

at du uttaler det ut ifra det da, ut ifra hvordan det høres ut i hodet sånn naturlig, enn at du liksom skal forandre på det for å høres med britisk eller mer amerikansk ut. Det er rett og slett bare å lese og snakke sånn som du føler er naturlig for deg (School C) that you pronounce it based on how it sounds in your head, like, naturally, not that you, like, change it to sound more British or more American. It's actually just reading and talking the way that feels natural to you

What is natural to these L2 speakers might be related to L2 exposure and to which pronunciation is accessible to them. The accessibility of accents and the rationale for the 'neutral' English aim is discussed in The functions of native accents and The role of social evaluations below.

Table 5 gives an overview of the reported accent aims. Nobody chose the option Norwegian. One participant (here in the Other category) circled both British and American and wrote "It can be useful to learn both". ${ }^{2}$ In contrast to the distinctive SSBE preference in the VGT results, the data in Table 5 shows that American is the dominant accent aim in the participant reports. This discrepancy between attitudes and reported aims is discussed below in The role of social evaluations. 
Table 5. Overview of responses to the question 'Which accent/pronunciation are you aiming at when you speak English?'

\begin{tabular}{cccccc}
\hline British & American & 'Neutral' & Other & $\begin{array}{c}\text { I don't } \\
\text { care }\end{array}$ & Total N \\
\hline 23 & 30 & 11 & 2 & 4 & 70 \\
\hline
\end{tabular}

Participants who had chosen either British English (BrE) or American English (AmE) as their accent aim were asked why they did not choose the other accent as aim. 26 answers by AmE aimers and 21 answers by BrE aimers produced a total of 66 reasons which were grouped and labelled according to content (Table 6).

Table 6. Motivations for accent choices with examples given by AmE aimers and BrE aimers

\begin{tabular}{|c|c|c|c|c|}
\hline Reason & $\begin{array}{c}\mathrm{N} \\
\operatorname{AmE} \\
\operatorname{aim}\end{array}$ & $\begin{array}{c}\mathrm{N} \\
\mathrm{BrE} \\
\text { aim }\end{array}$ & Description & Example \\
\hline Access & 16 & 2 & $\begin{array}{l}\text { Accent feels more } \\
\text { natural, easier, more } \\
\text { accessible }\end{array}$ & $\begin{array}{l}\text { Because I find American English } \\
\text { easier to pronunciate and it's } \\
\text { talked more on TV, so it's the } \\
\text { language I hear the most. }\end{array}$ \\
\hline $\begin{array}{l}\text { Linguistic } \\
\text { quality }\end{array}$ & 4 & 12 & $\begin{array}{l}\text { Accent more aesthetic } \\
(\mathrm{N}=15) \text { or intelligible } \\
(\mathrm{N}=1)\end{array}$ & $\begin{array}{l}\text { I think British English sounds } \\
\text { better }\end{array}$ \\
\hline $\begin{array}{l}\text { Status and } \\
\text { Competence }\end{array}$ & $\begin{array}{c}6 \\
(\text { neg) }\end{array}$ & 10 & $\begin{array}{l}\text { Accent associated } \\
\text { with/not associated } \\
\text { with e.g. formality, } \\
\text { class, intelligence, } \\
\text { education }\end{array}$ & $\begin{array}{l}\text { because British English is more } \\
\text { classy, and sounds nicer and less } \\
\text { vulgar } \\
\text { I feel that American English is } \\
\text { more relaxed, and not VERY } \\
\text { Formal. }\end{array}$ \\
\hline Validity & 0 & 4 & $\begin{array}{l}\text { Accent is the real and } \\
\text { original English }\end{array}$ & $\begin{array}{l}\text { Well, I do think British English is } \\
\text { and was the original English } \\
\text { while American just "happened". }\end{array}$ \\
\hline $\begin{array}{l}\text { Authenticity/ } \\
\text { Markedness }\end{array}$ & 4 & 0 & $\begin{array}{l}\text { Accent sounds right or } \\
\text { appropriate and not } \\
\text { fake/Accent is more } \\
\text { neutral }\end{array}$ & $\begin{array}{l}\text { (British English is harder), and if } \\
\text { you don't quite get it right, you } \\
\text { would just sound stupid, and } \\
\text { people would think you are trying } \\
\text { hard to be something you are not. }\end{array}$ \\
\hline Other & 2 & 3 & $\begin{array}{l}\text { Audience or social } \\
\text { attractiveness reasons }\end{array}$ & $\begin{array}{l}\text { because I think American english } \\
\text { [is] not so boring such as british }\end{array}$ \\
\hline
\end{tabular}

Note: Examples are copied verbatim from the questionnaire, which was given and responded to in English 
A few main patterns are identifiable in the reasons given for accent aims. First, the most common reason to aim towards an American English accent was accessibility. Two of the AmE aimers who gave Access as reason pointed out that British English nevertheless sounded better. Another two AmE aimers in this category explicitly reported TV to be the reason for accessibility. Second, the most common reason to aim towards a $\mathrm{BrE}$ accent was aesthetics. One of the BrE aimers in this category pointed out that AmE was easier, but a ugly language. Third, another common reason for aiming towards $\mathrm{BrE}$ was that this accent was associated with status and competence qualities such as education, formality or class. These associations to British English were also a common reason to not choose this accent (cf. '(neg)' in Table 6), but rather the less formal American English. Finally, in addition to reasons related to status and competence and linguistic quality (mostly in favour of $\mathrm{BrE}$ ), and accessibility (mostly related to AmE), there was also a matter of markedness: British English is considered the original English, but L2 speakers of this accent might easily sound like they are trying too hard, and American English is the more neutral choice.

\section{DISCUSSION}

\section{The functions of native accents}

Agreement in the VGT results across social groups gender, school, home language and accent aim suggests a shared set of attitudes towards English accents among Norwegian learners. The almost unanimous endorsement of the SSBE voices suggests that this accent is by far regarded as the most prestigious English accent, which is in line with evaluative patterns in other non-native speaker contexts (e.g. Dalton-Puffer, et al., 1997; Jarvella, et al., 2001). The attitudes towards SSBE that emerged from the VGT results were supported by accent aim motivations reported in the questionnaire (Table 6); British English was repeatedly reported to be chosen for reasons related to status and competence and linguistic quality. Thus SSBE seems to maintain its status as a superior 'standard', also in the ELT context in Norway. The standard ideological value of SSBE, however, varies according to gender; the female SSBE speakers were judged superior to male counterparts on all dimensions. This suggests that standard forms might be a more favourable social investment for female speakers, as commonly suggested in sociolinguistic research (e.g. Eckert \& McConnell-Ginet, 1999; Trudgill, 1972).

Considering the substantial exposure to American English through the media, one would expect that this accent would be widely accepted among Norwegian adolescents. 
Instead, GenAm is mostly rated similarly to the less recognisable $\mathrm{ScE}$ and Leeds accents. The media-dominated variety is not, then, as in Kristiansen (2001), considered a second and more informal 'standard', even though this accent has an equally high identification rate as the prestigious SSBE. However, access was reported as reason to aim towards this accent; AmE was regarded as easier and more 'natural'. This suggests that the dominance of AmE in the popular media makes this accent more available and subsequently affects learners' English language choices - a suggestion also given by participants themselves in some cases (cf. Table 6). Increased access from exposure, then, justifies the choice of AmE as accent aim instead of the highly rated BrE.

Conversely, though, high evaluation scores do not necessarily mean accent preference; SSBE is rated higher for as diverse traits as attractiveness, authority and urbanity, and although most of the scales in the VGT could be interpreted as positive-negative bipolar scales, this is not necessarily always so, for instance for traits such as ambition or formality. Some qualities might not always be approved of, or they might not be important, or they might not be attributes speakers want to convey. The high SSBE ratings suggest that the participants' judgements are overall stronger for this accent, so that SSBE is in some way more marked than GenAm, ScE and Leeds. British English was in fact reported to be avoided because of its markedness - an attempt to use this accent is more easily noticed, and it is more difficult to pass as an 'authentic' speaker of this variety (cf. Table 6). This markedness is explained in the following quote from one of the focus-group interviews:

folk som snakker britisk virker som overachievers fordi da får man liksom inntrykk av at de enten har bodd i utlandet i sånn britisk-snakkende sted liksom eller så har de bare prøvd sånn sinnsykt hardt på skolen liksom [...]

hvis jeg plutselig skulle begynne å snakke britisk så ville det bare vært rart fordi jeg bor ikke i Storbritannia jeg er ikke brite og jeg er ikke påvirket av britisk kultur i det hele tatt liksom, så det ville liksom forandret på deler av identiteten (School C) people who speak British seem like overachievers because then you, like, get the impression that they either lived abroad in, like, a British-speaking place or they've just, like, tried insanely hard in school [...]

if I suddenly should have started speaking British then that would just be weird because I don't live in Great Britain I'm not a Brit and I'm not influenced by British culture, like, at all, so that would, like, change parts of the identity

British English, then, is assigned a formal function, related to competence and school. These status and authority attributes are not necessarily desired by all speakers. Coupland (2009: 44) 
argues that, also for native speakers, "the 'superiority' of RP was often a two-edged sword in social evaluative terms", because RP speakers are associated with the less credible quality 'posh'. American English was in fact repeatedly reported as aim because it was not associated with status and competence, and seems to be assigned an informal function. In addition to these opposing formality functions of the two native accents, the $\mathrm{BrE}$ choice is more marked; the accent might convey that the speaker is trying too hard (cf. Table 6). The evaluative ambiguity and markedness related to BrE suggests that this accent is less socially accessible to learners than AmE.

\section{The role of social evaluations}

Although one evaluational pattern emerges from the combination of methodologies, there is nevertheless a discrepancy between the VGT attitudes and the reported accent aims. The attitudes that emerge from the evaluation test would suggest that a British English accent would be the dominant L2 choice among the Norwegian learners, but only 23 out of 70 participants reported this as accent aim. Furthermore, in an investigation of the pronunciation of phonological variables among Norwegian learners, Rindal (2010) shows that the dominant variants in the L2 production are those also found in American English. Among Norwegian learners, then, an L2 continuum of native-accent preference is formed; from the BrE authority reflected in the attitudes elicited from the VGT on one end, via the diverse accent aims which emerged from the qualitative data, and to AmE dominance in the L2 production on the other end.

The interconnectedness of the elements in this L2 continuum is not immediately evident. Kristiansen (2001) argues that it is the 'unaware' judgements elicited in techniques such as the matched-guise test, not reported language choices, which ultimately lead to actual language behaviour. In the L2 context, this does not seem to be the case; second language behaviour is more closely linked to reported aims and motivations rather than the attitudes elicited with the speaker evaluation test. ${ }^{3}$ This is confirmed in Rindal (2010), where speakers' realisation of L2 phonological variables correlated significantly with reported accent aims. The attitudes - aims - behaviour continuum suggests that other factors and constraints apart from social evaluations are likely to have an impact on actual language behaviour. The perceived linguistic and social accessibility of American English resources, for instance, is likely to constrain L2 choices. Although there clearly are social meanings attached to English accents, knowledge of L2 linguistic resources and their attributes might be restricted, and consequently less importance might be given to social meaning when making L2 choices. 
Even though the impact of social evaluations on language choices and behaviour might be restricted in a second language, speakers nevertheless report that the most widely used native accents are associated with values and attributes that they might not always wish to convey. While the more accessible American English for some becomes the less marked L2 accent, 11 out of 70 participants reported an altogether 'neutral' accent aim. In all three focusgroup interviews, this was argued to represent a wish to not use any of the widely identified English accents:

jeg tror mange av oss også vil være nøytrale fordi jeg vil liksom bli oppfattet som en som faktisk kan språket ikke sånn jeg vil liksom ikke bli oppfattet som en amerikaner eller som en brite (School C)

I think many of us want to be neutral because I want to, like, be thought of as someone who actually knows the language, not, like, I don't want to, like, be thought of as an American or a Brit

The reported desire to use a neutral variety of English (i.e. using variants in between established variants, cf. English accent aims above) suggests that L2 choices are socially meaningful, even though they might be restricted by accessibility. The L2 strategy among some Norwegian learners seems to be an attempt to avoid the associations related to nativespeaker accents by not aiming towards any recognisable English variety.

\section{Methodological limitations}

Although this study attempted to control for speaker attributes other than accent by including two speakers of each gender in each main accent group, and by controlling for age, education, content, speech rate and obvious differences in reading animation, it is not possible to completely avoid that speakers and listeners interact and interpret the text individually. A critical inspection of the evaluation results for the individual voices shows that attributes other than language could likely have influenced participant judgement for one of the stimulus speakers. Table 7 presents the means for each individual voice. These results show that the individual voices do in fact pattern into gender and accent groups, reflecting the categorisation made by the study design. The only exception to this accent/gender pattern in the overall means is GenAm/F1 (Voice 2), who is separated from GenAm/F2 (Voice 10) in the ordered list of ratings. In fact, there is a significant difference in the overall mean scores between these two speakers $(p=<0.05)$ in the STATUS AND COMPETENCE dimension. This intra-group difference suggests that GenAm/F1 (Voice 2) is at least to a certain degree 
evaluated differently because of some other speaker attribute, for instance pitch variability which can be interpreted by listeners as level of animation.

Table 7. Mean evaluation scores for the three PCA dimensions by individual voices

\begin{tabular}{|c|c|c|c|c|c|}
\hline \multirow{2}{*}{\multicolumn{2}{|c|}{$\begin{array}{l}\text { STATUS \& } \\
\text { COMPETENCE }\end{array}$}} & \multirow{2}{*}{\multicolumn{2}{|c|}{$\begin{array}{l}\text { SOCIAL } \\
\text { ATTRACTIVENESS }\end{array}$}} & \multirow{2}{*}{\multicolumn{2}{|c|}{$\begin{array}{l}\text { LINGUISTIC } \\
\text { QUALITY }\end{array}$}} \\
\hline & & & & & \\
\hline SSBE/F2 & $4.17(0.56)$ & $\mathrm{SSBE} / \mathrm{F} 1$ & $3.85(0.65)$ & $\mathrm{SSBE} / \mathrm{F} 1$ & $4.74(0.42)$ \\
\hline SSBE/F1 & $4.09(0.58)$ & SSBE/F2 & $3.67(0.59)$ & SSBE/F2 & $4.60(0.41)$ \\
\hline SSBE/M2 & $3.59(0.68)$ & GenAm/M2 & $3.45(0.82)$ & SSBE/M1 & $4.20(0.70)$ \\
\hline SSBE/M1 & $3.58(0.79)$ & GenAm/F2 & $3.26(0.89)$ & SSBE/M2 & $4.08(0.75)$ \\
\hline GenAm/M1 & $3.34(0.60)$ & GenAm/M1 & $3.10(0.59)$ & GenAm/F2 & $3.89(0.62)$ \\
\hline $\mathrm{ScE} / \mathrm{M}$ & $3.15(0.66)$ & $\mathrm{ScE} / \mathrm{F}$ & $3.08(0.77)$ & GenAm/M2 & $3.80(0.88)$ \\
\hline GenAm/F2 & $3.12(0.74)$ & SSBE/M1 & $3.08(0.73)$ & GenAm/M1 & $3.77(0.83)$ \\
\hline GenAm/M2 & $3.10(0.63)$ & SSBE/M2 & $3.00(0.70)$ & $\mathrm{ScE} / \mathrm{M}$ & 3.49 (0.99) \\
\hline $\mathrm{ScE} / \mathrm{F}$ & $3.08(0.74)$ & $\mathrm{ScE} / \mathrm{M}$ & $3.00(0.72)$ & GenAm/F1 & $3.47(0.89)$ \\
\hline GenAm/F1 & $2.69(0.76)$ & GenAm/F1 & $2.91(0.82)$ & $\mathrm{ScE} / \mathrm{F}$ & 3.44 (0.99) \\
\hline
\end{tabular}

Note: Standard deviations in parenthesis.

However, all other individual speakers grouped into their respective gender and accent categories. This is also the case for the two speakers who produced two voices each; SSBE/M2 (Voice 9) was evaluated similarly to SSBE/M1 (Voice 1), and SSBE/F1 (Voice 5) grouped with SSBE/F2 (Voice 8), as intended by the methodology. Furthermore, the female speaker who produced Voices 5 and 11 elicited significantly higher scores when using an SSBE accent than when reading with a $\mathrm{ScE}$ accent $(\mathrm{p}<0.001)$, for all dimensions. This supports the inclusion of matched-guise voices alongside verbal-guise voices to strengthen the study design. However, the judgement of other speaker attributes in one of the GenAm females points to limitations in the methodology. In addition, speaker evaluation techniques have a salience problem, i.e. the unnatural focus of systematically asking participants to listen to and judge a series of speech recordings with a repeated content. These limitations suggest that a controlled test is not sufficient to access language ideologies. Therefore, the VGT results were in this study supported by data from a questionnaire and focus-group interviews.

\section{IMPLICATIONS AND FURTHER RESEARCH}

The modified verbal-guise test combined with more open-ended data revealed a shared set of language attitudes towards English accents among the Norwegian learners. The formal, school-oriented British English seems to be considered the more marked accent, and is 
therefore by some avoided as L2 accent aim. American English is more accessible, and is perhaps because of this the preferred accent aim. However, a reported desire to use a neutral variety of English suggests that L2 speakers might not always wish to convey the values and cultures of native varieties. This suggests that a model of pronunciation offered to EFL students as 'correct' is not unproblematic; there are social meanings associated to native accents of English that might prevent learners from wanting to use these. At the same time, 'standard' varieties of American English and British English are by far the most recognisable worldwide, and might therefore be relevant learner targets. It follows from the results in the present study, that critical distance is necessary in the use of target accents in English language teaching. More research is needed to explore learners' preferred models, as well as teacher attitudes towards available target accents.

The data reveal an L2 continuum of attitudes - choices - behaviour, where it is difficult to determine the driving-force of variation (Kristiansen, 2011) - the role and impact of social evaluations, language behaviour and accessibility on language variation. The results suggest that the relationship between attitudes and behaviour is different in an L2 than in an L1. More research is needed into the processes between social motivations and language behaviour among speakers of a second language, as well as into the L2 strategies and styles (Coupland, 2007; Eckert \& Rickford, 2001) of individual speakers.

Language ideologies are likely to be affected by other factors and constraints on evaluation, such as stance towards the evaluation and accessibility of linguistic and social resources. Although these other factors might play a considerable role in an L2, the language attitudes and choices that emerged here suggest that social meanings related to English accents are in fact resources in Norwegian learners' L2. This level of L2 repertoire renders the label 'learners' problematic. Although the label is used in the title and throughout this article to situate the research in the ELT context, the use of resources from English to negotiate social meaning suggests that these participants are predominantly L2 speakers, not first and foremost L2 learners. As such, it might not be constructive to treat English like a foreign language in school contexts. Educators in Norway and countries with similar English language conditions should take this L2 speaker status into account in the development and practice of English language teaching. 


\section{NOTES}

${ }^{1}$ These three language-related qualities were already categorised into a separate component in the evaluation form, but it is difficult to say whether the PCA is a confirmation of this precategorisation, or whether the PCA results might have been formed by the construction of the evaluation form. Either way, there is no reason to suspect that the PCA results would have been different if there was no such pre-categorisation in the evaluation form.

${ }^{2}$ This suggests that the methodology might have restricted the participants' responses; although the response alternatives were constructed based on pilots and previous research (Rindal, 2010), an open-ended rather than closed-ended question might have elicited more informative responses.

${ }^{3}$ Investigating differences between 'aware' and 'unaware' evaluative patterns was not a primary aim in the present study. Contrary to Kristiansen (2001), it is likely that there in the present study was in fact an awareness of language as object of evaluation among the participants.

\section{REFERENCES}

Auer, P. (2005). Europe's sociolinguistic unity, or: A typology of European dialect/standard constellations. In N. Delbecque, J. van der Auwera \& D. Geeraerts (Eds.), Perspectives on variation: Sociolinguistic, historical, comparative (pp. 7-42). Berlin: de Gruyter.

Bex, T. (2008). 'Standard' English, discourse grammars and English language teaching. In M. A. Locher \& J. Strässler (Eds.), Standards and norms in the English language (pp. 221-238). Berlin and New York: Mouton de Gruyter.

Bex, T., \& Watts, R. J. (Eds.). (1999). Standard English: The widening debate. London: Routledge.

Bonnet, G. (2004). The assessment of pupils' skills in English in eight European countries 2002. Paris: The European Network of Policy Makers for the Evaluation of Education Systems.

Coupland, N. (2007). Style: Language variation and identity. Cambridge: Cambridge University Press.

Coupland, N. (2009). Dialects, standards and social change. In M. Maegaard, F. Gregersen, P. Quist \& J. N. Jørgensen (Eds.), Language attitudes, standardization and language change (pp. 27-49). Oslo: Novus forlag.

Coupland, N., \& Bishop, H. (2007). Ideologised values for British accents. Journal of Sociolinguistics, 11(1), 74-93.

Dalton-Puffer, C., Kaltenboeck, G., \& Smit, U. (1997). Learner attitudes and L2 pronunciation in Austria. World Englishes, 16(1), 115-128.

Dürmüller, U. (2008). Towards a new English as a foreign language curriculum for Continental Europe. In M. A. Locher \& J. Strässler (Eds.), Standards and norms in the English language (pp. 239-253). Berlin and New York: Mouton de Gruyter.

Eckert, P., \& McConnell-Ginet, S. (1999). New generalizations and explanations in language and gender research. Language in Society, 28, 185-201.

Eckert, P., \& Rickford, J. (Eds.). (2001). Style and sociolinguistic variation. Cambridge: Cambridge University Press.

Education Act, Act of 17 July 1998 no. 61 relating to Primary and Secondary Education and Training. Education First. (2011). EF English Proficiency Index.

Evans, B. E., \& Imai, T. (2011). 'If we say English, that means America': Japanese students' perceptions of varieties of English. Language Awareness, 20(4), 315-326.

Garrett, P. (2010). Attitudes to language. Cambridge: Cambridge University Press.

Giles, H. (1970). Evaluational reactions to accents. Educational Review(22), 211-227.

Graedler, A.-L., \& Johansson, S. (2002). Rocka, hipt og snacksy: Om engelsk $i$ norsk språk og samfunn [About English in Norwegian language and society]. Kristiansand: Norwegian Academic Press. 
Hellekjær, G. O. (2007). Fremmedspråk i norsk næringsliv - engelsk er ikke nok! (Vol. 3). Halden: Fremmedspråksenteret.

Herseth, S. K. (2009). Engelsklærer vil bruke Jagland-tale i undervisningen [English teacher wants to use Jagland speech in class], Dagbladet. Retrieved from http://www.dagbladet.no/2009/12/10/nyheter/innenriks/obama/fredspris/jagland/9445365/

International Phonetic Association. (1999). Handbook of the International Phonetic Association: A guide to the use of the International Phonetic Alphabet. Cambridge: Cambridge University Press.

Jarvella, R. J., Bang, E., Jakobsen, A. L., \& Mees, I. M. (2001). Of mouths and men: Non-native listeners' identification and evaluation of varieties of English. International Journal of Applied Linguistics, 11(1), 37-56.

Kachru, B. (1985). Standards, codification and sociolinguistic realism: The English language in the outer circle. In R. Quirk \& H. G. Widdowson (Eds.), English in the world: Teaching and learning the language and literatures (pp. 11-30). Cambridge: Cambridge University Press.

Kristiansen, T. (2001). Two standards: One for the media and one for the school. Language Awareness, 10(1), 9-24.

Kristiansen, T. (2011). Attitudes, ideology and awareness. In R. Wodak, B. Johnstone \& P. Kerswill (Eds.), The SAGE handbook of sociolinguistics: SAGE.

Kristiansen, T., Garrett, P., \& Coupland, N. (2005). Introducing subjectivities in language variation and change. Acta Linguistica Hafsniensia, 37, 9-35.

Ladegaard, H., J. (1998). National stereotypes and language attitudes: The perception of British, American and Australian language and culture in Denmark. Language and Communication, 18(4), 251-274.

Lambert, W. E., Hodgson, R. C., Gardner, R. C., \& Fillenbaum, S. (1960). Evaluational reactions to spoken languages. Journal of Abnormal and Social Psychology, 60(1), 44-51.

Ljosland, R. (2010). Teaching through English: Monolingual policy meets multilingual practice. Hermes - Journal of Language and Communication Studies, 45, 99-113.

Locher, M. A., \& Strässler, J. (Eds.). (2008). Standards and norms in the English language. Berlin and New York: Mouton de Gruyter.

Lund, A. (2006). The multiple contexts of online language teaching. Language Teaching Research, $10(2), 181-204$.

McKenzie, R. M. (2006). A quantitative study of the attitudes of Japanese learners towards varieties of English speech: Aspects of the sociolinguistics of English in Japan. (Doctoral dissertation). The University of Edinburgh, Edinburgh.

Milroy, J. (2007). The ideology of the standard language. In C. Llamas, L. Mullany \& P. Stockwell (Eds.), The Routledge companion to sociolinguistics (pp. 133-139). London and New York: Routledge.

Ministry of Education and Research. (2006). National curriculum for knowledge promotion in primary and secondary education and training. English subject curriculum. Oslo: Ministry of Education and Research.

Phillipson, R. (1992). Linguistic imperialism. Oxford \& New York: Oxford University Press.

Preston, D. R. (2002). Language with an attitude. In J. K. Chambers, P. Trudgill \& N. Schilling-Estes (Eds.), The handbook of language variation and change. Oxford: Blackwell Publishing.

Rindal, U. (2010). Constructing identity with L2: Pronunciation and attitudes among Norwegian learners of English. Journal of Sociolinguistics, 14(2), 240-261.

Røyneland, U. (2009). Dialects in Norway - catching up with the rest of Europe? International Journal of the Sociology of Language, 196/197, 7-31.

Sandøy, H. (2011). Language culture in Norway: A tradition of questioning standard language norms. In T. Kristiansen \& N. Coupland (Eds.), Standard languages and language standards in a changing Europe. Oslo: Novus Press.

Sarnoff, I. (1970). Social attitudes and the resolution of motivational conflict. In M. Jahoda \& N. Warren (Eds.), Attitudes (pp. 279-284). Harmondsworth: Penguin.

Trudgill, P. (1972). Sex, covert prestige and linguistic change in the urban British English of Norwich. Language in Society, 1, 179-195. 
van der Haagen, M. (1998). Caught between norms: The English pronunciation of Dutch learners. Hague: Holland Academic Graphics.

Wells, J. C. (1982). Accents of English. Cambridge: Cambridge University Press.

Xu, W., Wang, Y., \& Case, R. E. (2010). Chinese attitudes towards varieties of English: A pre-Olympic examination. Language Awareness, 19(4), 249-260. 


\section{APPENDIX 1: The instructions and scales from the VGT evaluation form.}

English translation in parenthesis.

Nå får du høre noen opptak av mennesker som snakker engelsk. Lytt til båndet og sett ring rundt passende karakter for hver person, 1 er minst og 5 er mest. For eksempel, hvis du synes personen som snakker høres ut som en veldig spennende person, sett ring rundt 5. Hvis personen høres veldig kjedelig ut, sett ring rundt 1.

Dette er $i k k e$ en test, vi vil vite hva $d u$ synes. Magefølelsen er ofte den riktige!

You will now hear some recordings of people who are speaking English. Listen to the tape and circle a grade for each person, 1 is the least and 5 is the most. For example, if you think the person talking sounds like a very interesting person, circle 5. If the person sounds very boring, circle 1.

This is not a test, we want to know what you think. Your first impression is often the right one!

Den som snakker er... (The person talking is...)

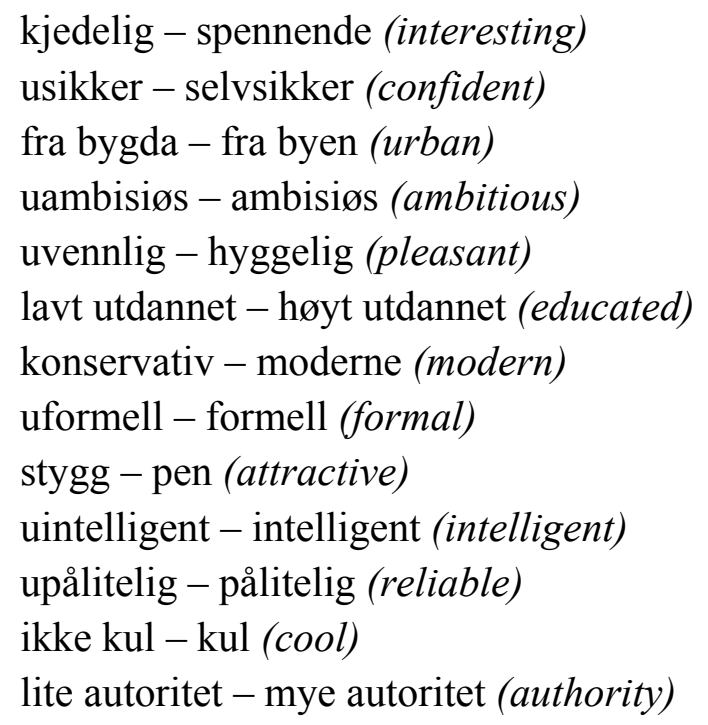

Uttalen er... (The pronunciation is...)

uforståelig - forståelig (intelligible)

uestetisk - estetisk (aesthetic)

(ikke fint å høre på) - (fint å høre på) ((not) pleasant to listen to)

dårlig uttalemodell - god uttalemodell (bad/good model of pronunciation)

(ikke ideal engelsk uttale) - (ideal engelsk uttale) ((not) ideal English pronunciation) 


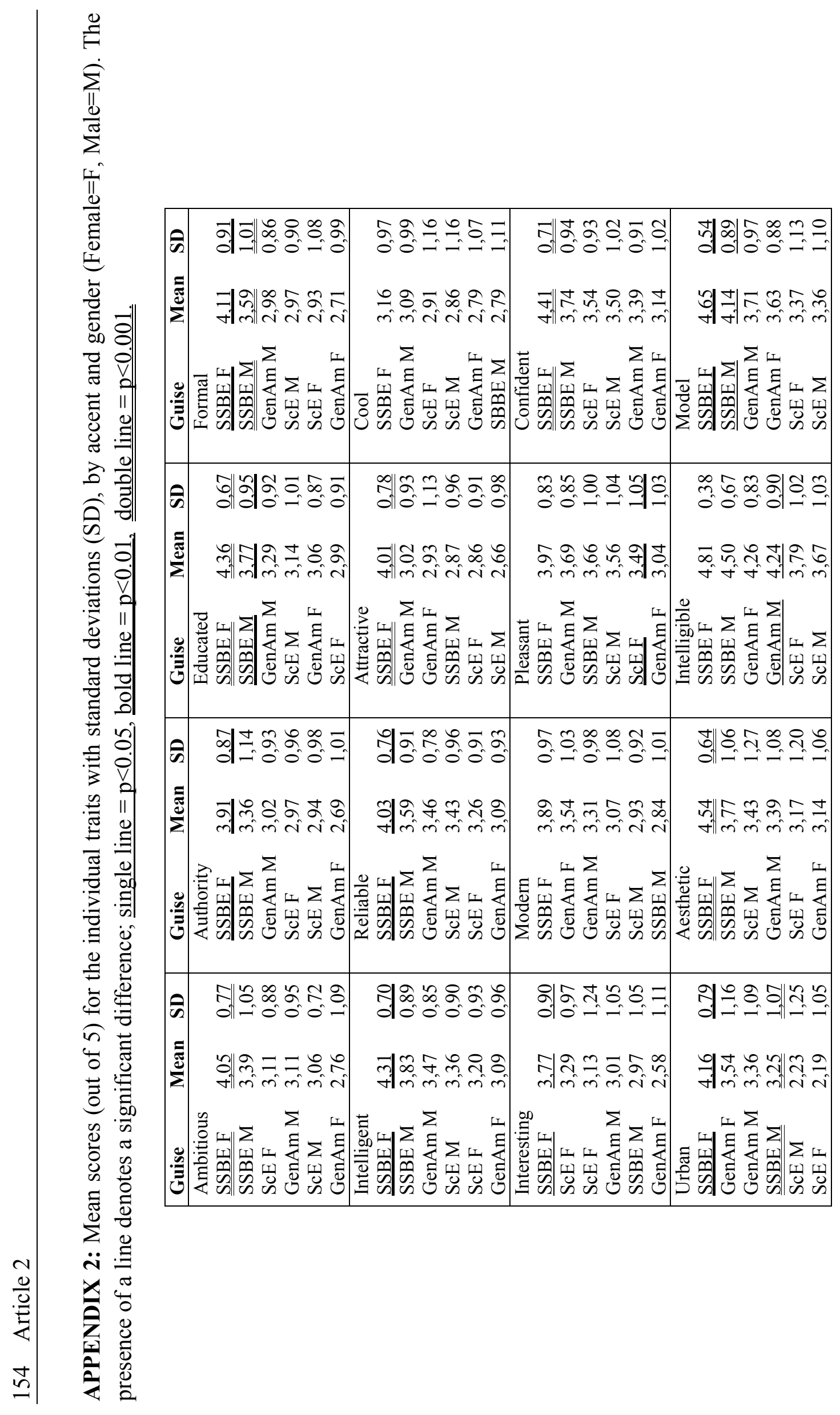




\title{
Article 3
}

\section{Being 'neutral'? English pronunciation among Norwegian learners" ${ }^{* 1}$}

\begin{abstract}
Following the global spread of English, more and more speakers appropriate English in their local environments. In Norway, the status of English is in transition, as English is no longer a 'foreign' language, but not quite a second language or lingua franca either. This study investigates the pronunciation of English among Norwegian adolescents by applying sociolinguistic methods in an L2 context. Results from an auditory analysis of seven phonological variables show a blended use of linguistic features from American English and British English, with some additional pronunciations, forming a hybrid and variable L2 accent. The participants' pronunciation aligns with their self-expressed target accents, but American English is the dominant pronunciation, suggesting influence from imported American media. Although the majority of learners aim towards a native accent, a large minority report a wish to avoid native accents and use a neutral variety of English. The variability in the local appropriation of English reflects the transitional status of English in Norway, and contributes to the increasing diversity in the development of English as a global language. The results have implications for English language educators, who must meet the needs of proficient learners in a transitional L2 environment.
\end{abstract}

\section{INTRODUCTION}

In an increasingly globalised world, English has become the foremost global language of communication. English is not only the result of a more economically, culturally and professionally interconnected world; it also provides the lingua franca that enables these connections (Jenkins, Cogo, \& Dewey, 2011). Because of this function as a transnational lingua franca, the status of English in the world is increasingly characterised by those who use it as a second or later language, rather than by its native speakers (Kirkpatrick, 2010a). English is not merely spread around the world, but appropriated by speakers in different communities. Speakers negotiate and re-enact English to meet communicative and situational demands - in this way, the globalised English is being constantly localised through its use. The global spread and local appropriation of English encourages the research of new and developing Englishes around the world.

\footnotetext{
${ }^{*}$ Co-authored with Caroline Piercy
} 
In response to the localisation of English around the world, language paradigms such as World Englishes (Kachru, 1992; Kirkpatrick, 2010b) and English as a lingua franca (ELF) (Jenkins et al., 2011; Seidlhofer \& Berns, 2009) acknowledge the diversity in the global community of English speakers and recognise the legitimacy of modern English varieties. A growing body of research describes and discusses the new Englishes which have developed (see e.g. Kachru, Kachru, \& Nelson, 2006; Kirkpatrick, 2010b). Most of this research has been conducted in postcolonial settings where English has official language status alongside one or more national languages and bilingualism has led to creole or indigenised Englishes. These new Englishes are characterised by a distinct set of linguistic properties, which can be accounted for by contact processes between English and the local language(s) and the historical development of the resulting new English variety (e.g. Schneider, 2010). Furthermore, an emerging research trend is the investigation of English used as a lingua franca by non-native speakers (see e.g. Jenkins et al., 2011 for an overview). Lingua franca English is typically characterised by linguistic properties and norms that are co-constructed and established in an ad hoc manner by speakers of different first languages in interactions where English is used to achieve a communicative goal (Seidlhofer, 2011). World Englishes and ELF thus offer frameworks for describing some of the new uses of English in the world.

In Norway, English has traditionally been taught as a foreign language, but increased intranational exposure and transnational travel and communication has led to improved language proficiency and confidence, and the development away from a function of 'foreign language' in the curriculum (KD, 2006). Although English retains its separate identity as a discipline in school, the English language is increasingly becoming part of speakers' linguistic repertoire. However, Norwegians do not qualify as speakers of English as a second language (ESL) under traditional descriptions (e.g. Graddol, 2006); they are neither speakers of New Englishes in postcolonial countries nor immigrants to a native-English-speaking country, and English does not have official language status in Norway. Furthermore, the English language teaching (ELT) situation in Norwegian schools does not reflect the description of ELF interactions, since English is not used as a lingua franca among Norwegians: although learners of English most likely will need English to communicate with speakers of other first languages, this is normally not the case when speaking English in school, where Norwegian language competence is a requirement. The participants in the present study are recorded in peer interactions in which they would speak Norwegian if not prompted to use English by the teacher, or in this case the fieldworker. The status of English in Norway is no longer that of 
EFL, but not quite ESL or ELF either, and seems thus to be caught between English language paradigms.

The transitional status of English in Norway reflects the negotiation between global development and local appropriation which characterises English in the world today, and this calls for investigations into the language variation of Norwegian speakers of English. By investigating the pronunciation of English among 70 Norwegian adolescents, and combining production results with reported language choices, this study explores the linguistic strategies applied by learners in a transitional ELT context. The following research questions are addressed:

1. What characterises the pronunciation of English among Norwegian learners?

2. How does English language use among learners relate to the status of English in Norway and the development of English as a global language?

The following section briefly considers the role of English for young Norwegians in school and in the larger society, as well as the general sociolinguistic climate of Norway. The production analysis is presented in Results, followed by a discussion of the appropriation and negotiation of English in Norway.

\section{English in Norway}

As in other European countries, Norwegians experience massive exposure to English through the media (Graedler, 2002), and the English language media targeted at adolescents is dominated by American popular culture (Rindal, 2010). Imported films and TV programmes are not dubbed but subtitled, and adolescents are confident users of new technologies and international media sources (ITU Monitor, 2009). In line with a general increase in the intranational use of ELF in Europe (Seidlhofer, 2011), English is widely used in Norwegian higher education and business domains (Ljosland, 2010; Språkrådet, 2011). Among their European peers, young Norwegians are among the most proficient L2 speakers of English (Bonnet, 2004; Education First, 2011), and their English language attitudes and behaviour suggest that English could be part of speakers' identity repertoire (Rindal, 2010).

Although Norway is traditionally an EFL country, there have been considerable developments in Norwegian ELT in the last decades. English is now a mandatory subject for ten years from year 1 (age six), and has its own syllabus separate from the other foreign 
languages. Considerable attention is paid to the global spread of English, exemplified by the first sentence in the national English subject curriculum: "The English language is used everywhere" $(\mathrm{KD}, 2006)^{2}$. Certain aspects of ELF influence the syllabus, such as emphasis on intelligibility, pragmatic strategies and intercultural competence. For instance, speaking and writing are described as tools in "the quest to understand and use English in ever more varied and demanding contexts that span special fields and cultures" (KD, 2006). However, although the focus is on learning about language, culture and society in "English-speaking countries" (KD, 2006) in general, no definition of this frequently used phrase is given. Although knowledge about the diversity of English is endorsed, native speaker communities are used as references to which other Englishes can be compared. For instance, the English subject aims to enable students to "give examples of other varieties of English than those that are used in the Anglo-American core area, and reflect on their distinctive character" (KD, 2006, emphasis added). Because of this general orientation around native speaker varieties, American English and British English were also used as references in the methodology of the present study.

The English language syllabus does not offer learners any specific variety as 'correct'. This is in line with ELF scholars' reservations about using external models as prestige models in ELT contexts (see Jenkins, 2006 for an overview), and contrary to traditional EFL practices. This lack of explicit standard is also in line with the general sociopolitical discourse on language in Norway. In the L1, Norway has two written languages, Bokmål and Nynorsk, which developed following a struggle for independence and national identity after three centuries of Danish dominance. The two written languages are given equal official status by the government, and after a failed reform mission to merge them into one single national language, both languages permit various forms and freedom of choice. This freedom of choice challenges the status of one indisputable homogenous norm, and the situation has resulted in an awareness among Norwegians that there is not one self-evident language form (Røyneland, 2009; Sandøy, 2011). Furthermore, the government's liberal stance towards written forms has led to increased acceptance of spoken forms, too. Using dialect is, in general, accepted by Norwegians, even preferred, and Norwegians are accustomed to considerable dialectal variation in public arenas (Sandøy, 2011). There is no explicit standard spoken variety in the form of a determined socially accepted linguistic variety, and schools are by law obligated to allow students to use their local spoken varieties, and even to adjust to these (Education Act §2-5; Røyneland, 2009). A large-scale study on attitudes towards English in the Nordic countries (Moderne importord $i$ språka $i$ Norden, translated Modern import words in the languages in the Nordic countries), showed that Norwegians are the most tolerant towards 
dialect use in the spoken media (Kristiansen \& Vikør, 2006). This project also showed that in this comparative framework Norwegians are also relatively tolerant towards the general advance and influence of English (Sandøy, 2007; Selback \& Kristiansen, 2006). There seems thus to be a general acceptance of spoken variation in Norway.

Without explicit external L2 models offered by educational authorities, and in a sociolinguistic climate where speakers generally are accustomed to and tolerant of variation, Norwegian learners make their own English language choices. It is therefore relevant to not only investigate participants' pronunciation, but also desired pronunciation. In addition to an investigation of L2 production, this study therefore considers participants' reports and commentary about target pronunciation when speaking English. It is appropriate to assume that because of the orientation around Anglo-American varieties, these native accents will be targeted by learners. However, in a previous study about pronunciation and attitudes among Norwegian learners, Rindal (2010) suggested that English language choices among Norwegian learners extend beyond an American/British English dichotomy. Therefore, the present study focuses specifically on the language choices which divert from traditional EFL practices of targeting native accents, and discusses L2 production and reported practice in relation to the public discourse about language in Norway, as well as to the development of English as a global language.

\section{A note on the use of sociolinguistic methods}

The shift in thinking about language from fixed and static to fluid and hybrid in language paradigms such as ELF resonates well with a similar shift in how language diversity is viewed within sociolinguistics. Many sociolinguists no longer view language as reflecting a set of stable demographic categories, but rather as a resource for social practice (e.g Coupland, 2007; Eckert, 2012). Within sociolinguistics, language variation is seen as structured rather than random, and its origin and spread is therefore the central object of investigation (Foulkes, 2006). This study therefore applies sociolinguistic methods in the investigation of the hybridity and variability of English among learners.

\section{METHODOLOGY}

\section{The participants and procedure}

This study investigates the speech of 70 Norwegian speakers of English; 38 females and 32 males. The participants were all 17 years of age and in their second year of upper secondary 
school. They were students in three different classes from three different schools located in three different parts of Oslo, the capital of Norway. All the schools (here referred to as Schools A, B and C) have relatively high admission standards, and the students consequently have relatively good grades from lower secondary school. Furthermore, all but one participant reported that they intended to go on to higher education. These students are thus assumed to be relatively academically oriented compared to the general student population of Norway. ${ }^{3}$ The participants represent well the demographics of urban multicultural Oslo with just under half reporting to have another home language in addition to, or instead of Norwegian. However, all participants reported to have resided mostly in the urban southeast of Norway, and therefore shared the same L1 Norwegian variety, namely Urban East Norwegian (UEN). The shared L1 variety was confirmed by production data; the participants were also recorded while speaking Norwegian and they all used a UEN variety, with some L1 influence for some of the speakers who had an additional home language. Table 1 gives an overview of the participants.

Table 1. Distribution of the participants by school, gender and home language

\begin{tabular}{lcclccccc}
\hline & \multicolumn{2}{c}{ Gender } & & \multicolumn{3}{c}{ Home language } & \\
\cline { 2 - 3 } School & Male & Female & & $\begin{array}{c}\text { Norwegian } \\
\text { only }\end{array}$ & $\begin{array}{c}\text { Other/additional } \\
\text { language }\end{array}$ & Unknown & Total \\
\hline School A & 15 & 5 & & 14 & 5 & 1 & 20 \\
School B & 9 & 17 & & 15 & 11 & - & 26 \\
School C & 8 & 16 & & 5 & 17 & 2 & 24 \\
\hline Total & 32 & 38 & & 34 & 33 & 3 & 70 \\
\hline
\end{tabular}

Despite the diversity of home languages there was homogeneity in their English speaking backgrounds; $90 \%$ of the participants had attended Norwegian school from year 1 meaning that most of the participants would have learnt English in the Norwegian school system, having studied English for nine years, as well as in Norwegian society more generally. $75 \%$ had never visited an English-speaking country for more than three weeks and reported having no special English language background (e.g. parents with English as L1, attending an English language school, etc.). Almost 90\% had never visited an English-speaking country for more than three months. At the time of the study, all participants had teachers of English who had Norwegian as L1 and English as L2 and who had undertaken their teacher education and training from the University of Oslo. 
The participants were recorded while speaking English in two conditions: first individually reading a word list of 40 words, and secondly having a casual conversation with a classmate of their choice. Approximately ten minutes of speech was recorded for each pair, yielding a total of five and a half hours of speech. After the data was elicited each participant was asked to complete a questionnaire written in English (see Accent aims below). To ascertain what type of English pronunciation participants were exposed to in class, the teachers' production was also recorded and analysed. All recordings were made with a Roland R09 recorder in stereo with a $44100 \mathrm{~Hz}$ sampling rate, and each participant wore a Sennheiser G2 wireless set with ME2 omnidirectional lavaliere microphone.

\section{The variables}

One of the aims for this study was to provide a broad overview of the English pronunciation used by the participants, and we therefore chose to examine seven different variable features of pronunciation: three vocalic and four consonantal. Furthermore, we wanted to examine the extent to which participants' production matched the English accent they reported as their target pronunciation. Therefore it was necessary to select features that differentiate native models of pronunciation; specifically the distinction between the reference accents of General American (GenAm) and Standard Southern British English (SSBE). The six features we chose to examine that differentiate GenAm from SSBE were the quality of the vowels in the lexical sets BATH, LOT and GOAT, the presence or absence of non-prevocalic $/ \mathrm{r} /$, the presence of intervocalic / $t$ / voicing, and finally the presence or absence of post-coronal $/ j /$. The first five of these variables are frequently described as salient distinguishing differences between GenAm and SSBE (e.g. Roach, Setter, \& Esling, 2011; Shockey, 1984; Tottie, 2002; Trudgill, 1986). Post-coronal / j/ is described as a distinction between GenAm and SSBE (e.g. Roach et al., 2011; Tottie, 2002), but in contrast to the other features it is not often described as salient. Finally, we chose to examine the realisation of voiceless $t h$, which is pronounced as a dental fricative $/ \theta /$ by speakers of both GenAm and SSBE, but sometimes replaced with $/ \mathrm{t} /$ by learners of English, since most of these, Norwegians included, do not have dental fricatives in their L1 (e.g. Cruttenden, 2008).

The variables were included in the word list task (except for Voiceless $t h$, which was added to the set of variables in retrospect) and examined in conversational speech. The word list consisted of 40 words, of which 26 contained variables of interest, and the remaining 14 were added as fillers. During the analysis, three items (atom, knowledge, fatal) were removed 
due to a considerable number of mispronunciations and hesitations which seemed to result from uncertainty about the interpretation of the orthography. The words which we analysed are presented in Table 2, and the word list as presented to participants appears as Appendix 1.

Table 2. The word list tokens included in the analysis

\begin{tabular}{l|l}
\hline Variable & Word list tokens \\
\hline BATH & dance, classroom, fast, glass \\
LOT & college, top, bottom, possible \\
GOAT & code, moment, goat, boat \\
Non-prevocalic $/ \mathrm{r} /$ & army, sister, whatever, fire \\
Intervocalic $/ \mathrm{t} /$ & whatever, bottom, mighty \\
Post-coronal $/ \mathrm{j} /$ & student, new, stupid, Tuesday \\
\hline
\end{tabular}

\section{Analysis}

The variables in both the word list and conversational speech were analysed auditorally. Narrow phonetic transcriptions were produced, taking an approach which included the following four stages: since we wanted to capture as much variation as possible within the scope of the study, we first listened to the recordings and produced preliminary transcriptions of the participants' realisations. After scanning the range of variants, we agreed on classificatory categories into which we believed we would be able to reliably classify realisations using auditory analysis. Although at this stage we were inclined to not assume pre-existing categories or variants, we interpreted most of the realisations to be similar to those also found in GenAm or SSBE accents of English, and we therefore classify the results with reference to these accents in subsequent sections. For five of the variables, realisations were produced which defied categorisation into one of the two main variants. Due to considerable variation, these were combined into an 'Other' category. For Intervocalic /t/ we added a fourth category. In the third stage we transcribed all the production data by classifying the realisations into the established categories. Both authors undertook the auditory analysis, coding three or four variables each. Finally, to ensure consistency and agreement in the results, a random sample of at least $15 \%$ of the total tokens was coded a second time by the other author. The consistency between the first and second coder was 82 $95 \%$ for the seven variables $(\mathrm{BATH}=93 \%, \mathrm{LOT}=83 \%, \mathrm{GOAT}=83 \%$, Non-prevocalic $/ \mathrm{r} /=$ $82 \%$, Intervocalic $/ \mathrm{t} /=95 \%$, Post-coronal $/ \mathrm{j} /=88 \%$, and Voiceless $t h=85 \%$ ). This satisfied us that our codings were reliable and accurate particularly given that the authors have different L1 backgrounds (Norwegian and SSBE). 
For each variable all possible tokens were extracted from the conversational data but no more than three instances of any lexical item were included. Tokens obscured by two people speaking at the same time were excluded. Most English proper names were included, except instances where the items could have been appropriated into Norwegian, e.g. geographical names, or where we had limited knowledge of the items, e.g. names of characters in video games. Mispronunciations were excluded. For the vowel variables, only stressed tokens were analysed. In total, 7376 tokens were analysed. 1609 of these tokens were from the word list data and the remaining 5767 came from the conversational speech. See Appendix 2 for the distribution of the tokens by variable and task. Nine participants were excluded from the analysis of conversational speech, because they had been recorded in three same-sex group conversations making it difficult to differentiate between the speakers during transcription and subsequent analysis. Some details specific to the analysis of individual variables are as follows:

- BATH: variants were identified as being either front [æ] or back [a:] which reflects the salient difference between SSBE and GenAm pronunciation. While there were some differences in the length of the front vowel e.g. [æ], [æ], [æ:] the realisation of longer variants of [æ] appeared to be due to its long intrinsic vowel length rather than attempts at truly long front vowels (see Piercy, 2010: 140-155 for a discussion about vowel duration of BATH). Both [æ] and [a:] have corresponding vowels in the UEN inventory (Kristoffersen, 2000).

- LOT: items belonging to the lexical set CLOTH (e.g. cross, moth, soft) were included in addition to LOT items. Due to the neutralising context, tokens were excluded where $/ \mathrm{w} /$ preceded the vowel. Tokens of the lexical item on were also removed, since these were normally realised in a much-reduced form. The two most common variants were identified as [a] and [p], which both correspond to contrasting phonemes in UEN (Kristoffersen, 2000), in addition to less common occurrences of [ $\Lambda]$, [0] and [ou].

- GOAT: we coded for the quality of the first element of the vowel, which could be either monophthongal or the onset of a diphthong. Variants were coded as a back [o] or front [ə] place of articulation in the onset, in addition to lower and more front variants such as $[0],[\Lambda]$ and $[a]$. UEN does not have reduced forms such as the midcentral schwa, and loan words from English with GOAT diphthongs are usually pronounced with a back variant (Graedler, 2002). 
- Non-prevocalic /r/: rhoticity was investigated in stressed and unstressed, word-final and word-internal environments. Word-final tokens in linking or neutralising contexts were excluded. In addition, all tokens of the item sort in the expression sort of were omitted, since these were normally realised in a much-reduced form. The variants that emerged from the analysis were either approximant $[\mathrm{r}]$, non-rhotic $\varnothing$, or other (rhotic or non-rhotic) variants such as [r], which is the realisation of $/ r /$ in UEN speech, [r] resulting from the merger of /rt/ (e.g. 'party', 'thirty'), and finally an apical [t, d, n] resulting from the merger of /r/ followed by an alveolar /t, $\mathrm{d}, \mathrm{n} /$, typical in Norwegian (Kristoffersen, 2000).

- Intervocalic /t/: only word-medial tokens were coded. The variants that emerged were $[\mathrm{t}],[\mathrm{c}],[\mathrm{d}]$ as well as other realisations such as fricatives, approximants or deletions. Intervocalic /t/ in UEN is never voiced, but [r] exists in the inventory as a realisation of $/ \mathrm{r} /$.

- Post-coronal /j/: tokens where a palatal approximant follows coronals in SSBE but not in GenAm were analysed. Both variants are possible in UEN. Coronal environments with a preceding /1/ e.g. absolutely and some tokens with a preceding /s/ e.g. super were excluded since $/ \mathrm{j} /$ presence here is a marked pronunciation for most speakers of British English. There were a minority of realisations of Tuesday as [t $\mathrm{fu}: z d e r]$; these were included as having $/ \mathrm{j} /$ presence since they imply some coalescence of $[\mathrm{t}]$ and $[\mathrm{j}]$.

- Voiceless th: this variable was examined in word-initial, word-medial and word-final environments. Realisations were $[\theta]$ and $[\mathrm{t}]$, as well as other voiced or backed realisations such as $[\mathrm{d}]$ and $[\mathrm{s}]$. UEN does not have $[\theta]$, and is thus often replaced by $[\mathrm{t}]$ (Graedler, 2002).

\section{RESULTS}

\section{Overall production}

Figure 1 shows the overall results for the production of the seven variables from the conversational data. ${ }^{4}$ Appendix 3 gives a table with numbers and percentages of variant use for each variable. In each pie chart in Figure 1 the variant that characterises GenAm English is presented in black and the variant also found in SSBE is presented in white. The figure demonstrates that for almost all the variables it is the variant that is also found in GenAm English that is favoured. The speakers are mostly rhotic $(82 \%)$, they tap or voice Intervocalic /t/ $(75 \%)$, use [æ] for BATH $(68 \%),[a]$ for LOT $(56 \%)$, and have a back onset for GOAT 
(81\%). One exception to this pattern is Post-coronal $/ \mathrm{j} /$, which is present in $77 \%$ of all tokens. However, although there is a preference for GenAm variants, Figure 1 also shows that there is considerable variation in the pronunciation of each variable. The most frequent realisation of Voiceless th was a voiceless fricative [ $\theta](76 \%)$, but there was a large minority of variants pronounced with a stop $[\mathrm{t}](17 \%)$.

BATH

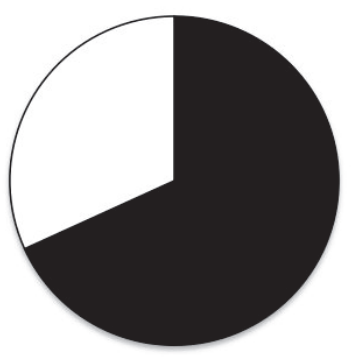

$\mathbf{\square}_{\mathfrak{a}} \square_{\mathrm{a}}$

NON-PREVOCALIC / $\mathbf{r}$ /

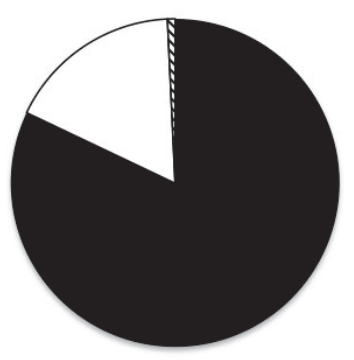

$\mathbf{v}_{\mathrm{r}}$ 口Ø $\mathbf{\Delta}$ OTHER
LOT

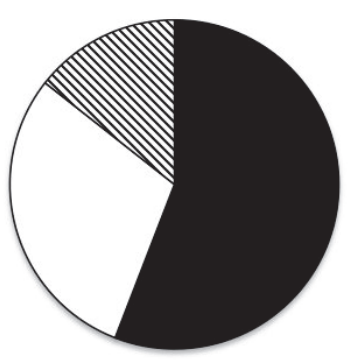

$\mathbf{v}_{\mathrm{a}} \square_{\mathrm{p}} \mathbf{\otimes}_{\mathrm{OTHER}}$

INTERVOCALIC / $/$ /

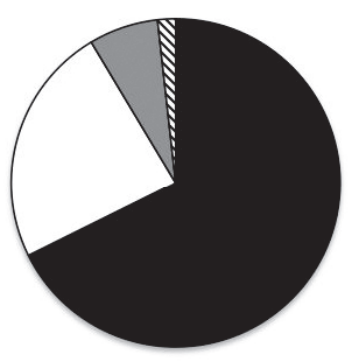

$\boldsymbol{v}_{\mathrm{f}} \square_{\mathrm{t}} \square_{\mathrm{d}} \mathbf{\Delta}_{\mathrm{OTHER}}$

VOICELESS $t h$

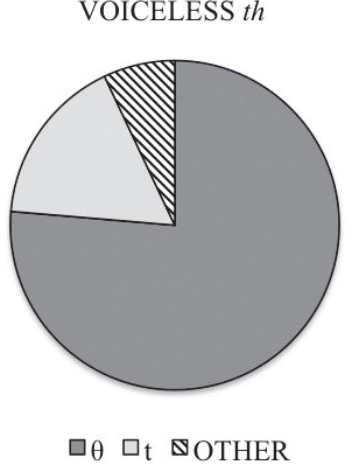

$\square_{\theta} \square_{\mathrm{t}} \mathbb{Q O T T H E R}^{2}$
GOAT

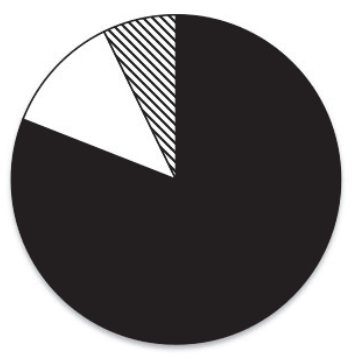

$\boldsymbol{\square}_{\mathrm{O}-} \square_{\text {ว- }} \mathbf{\Phi}_{\mathrm{OTHER}}$

POST-CORONAL /j/

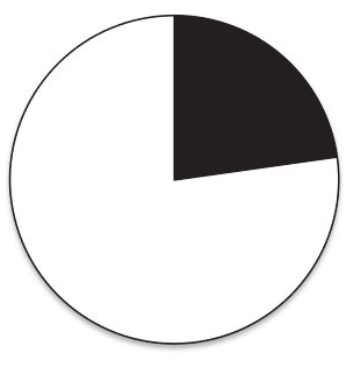

$\mathbf{v}_{\varnothing \mathrm{j}}$

Figure 1. Overall production of each variable in conversational speech $\mathrm{N}($ from left to right $)=346,868,972,2280,396,123,782$ 
Statistical tests were performed to explore patterns in the linguistic variation. Paired samples t-tests were conducted in order to investigate production across speech situations, and significant differences between word list and conversations were found for Non-prevocalic /r/, Intervocalic / $t /$ and LOT. The word list elicited more rhotic variants than the conversation $(\mathrm{p}<0.001)$, as well as more $[\mathrm{t}](\mathrm{p}<0.001)$ and variants other than $[\mathrm{t}],[\mathrm{d}]$ or $[\mathrm{r}](\mathrm{p}<0.01)$ for Intervocalic /t/. In addition, for LOT, [p] was used more in the word list than in conversation $(\mathrm{p}<0.001)$. The preference for $[\mathrm{r}],[\mathrm{t}]$ and $[\mathrm{p}]$ in the word list might be accounted for by the effect of orthography, rather than social reasons. There is no voiced realisation of orthographic $t$ or zero pronunciation of orthographic $r$ in Norwegian, and orthographic $o$ is mostly pronounced with an [v]-, [p]- or [0]-like quality. The reduction of Non-prevocalic /r/ and voicing of Intervocalic $/ \mathrm{t} /$ in the conversations could also indicate fluency in rapid speech, a pattern also found among native speakers (Tollfree, 1999).

Table 3. The production of the seven variables for the English teachers in schools A, B and C

\begin{tabular}{|c|c|c|c|c|}
\hline Variable & Variants & $\begin{array}{c}A \% \\
(N=140)\end{array}$ & $\begin{array}{c}\text { B \% } \\
(\mathrm{N}=\mathbf{8 6})\end{array}$ & $\begin{array}{c}C \% \\
(N=131)\end{array}$ \\
\hline \multirow{3}{*}{ BATH } & $æ$ & 5 & 100 & 25 \\
\hline & a & 75 & 0 & 75 \\
\hline & OTHER & 20 & 0 & 0 \\
\hline \multirow{3}{*}{ LOT } & $\mathrm{a}$ & 0 & 65 & 30 \\
\hline & $\mathrm{p}$ & 100 & 30 & 25 \\
\hline & OTHER & 0 & 5 & 45 \\
\hline \multirow{3}{*}{ GOAT } & o- & 45 & 100 & 60 \\
\hline & ə- & 50 & 0 & 30 \\
\hline & OTHER & 5 & 0 & 10 \\
\hline \multirow{3}{*}{ Non-prevocalic /r/ } & $\mathrm{r}$ & 0 & 85 & 10 \\
\hline & $\varnothing$ & 100 & 15 & 85 \\
\hline & OTHER & 0 & 0 & 5 \\
\hline \multirow{4}{*}{ Intervocalic /t/ } & ᄃ & 35 & 100 & 25 \\
\hline & $\mathrm{t}$ & 60 & 0 & 65 \\
\hline & $\mathrm{d}$ & 5 & 0 & 5 \\
\hline & OTHER & 0 & 0 & 5 \\
\hline \multirow{2}{*}{ Post-coronal /j/ } & $\varnothing$ & 0 & 100 & 0 \\
\hline & $\mathrm{j}$ & 100 & 0 & 100 \\
\hline \multirow{3}{*}{ Voiceless $t h$} & $\theta$ & 100 & 100 & 90 \\
\hline & $\mathrm{t}$ & 0 & 0 & 5 \\
\hline & OTHER & 0 & 0 & 5 \\
\hline
\end{tabular}


Since the participants were students with English as a school subject, it might be predicted that their English teachers would have influenced their L2 pronunciation. Table 3 presents the realisation of the phonological variables for the three teachers in the three schools. Table 3 shows that while the School A teacher produced a majority of variants characteristic of SSBE, albeit with some variation, the teacher in School B produced mostly GenAm features. The School C teacher's pronunciation, on the other hand, showed considerable variation. One-way ANOVA with Post-Hoc Bonferroni was performed with school as independent variable in order to investigate whether school factors such as teacher, school culture or intra-city geographical location had an effect on student pronunciation. Across the three schools and the seven variables, only one significant difference emerged: School $\mathrm{C}$ was found to use more [æ] than Schools A and B $(p<0.05)$ for the quality of BATH. Otherwise, there were no school effects on production. Furthermore, t-tests were conducted with gender and home language as independent variables. A small number of significant results returned (see Appendix 4), but considering the large number of tests, these were not regarded as substantial, and they did not seem to pattern in any consistent manner.

\section{Accent aims}

The most important and revealing results emerged when the variation was examined by the participants' own reported language choices. In a questionnaire administered after the recordings, the participants were asked to report which pronunciation they aimed towards when they spoke English; British, American, Norwegian, 'Neutral', Other, or I don't care. Choices reported by the participants are referred to here as 'accent aims'.

Previous research suggests that American English and British English are the most widely identified English accents in learner contexts (e.g. Dalton-Puffer, Kaltenboeck, \& Smit, 1997; Ladegaard, 1998). These native accents were therefore included as accent aim alternatives. The option Norwegian English is commonly used among the public to refer to English with Norwegian L1 influence, and accents with very distinct L1 influence are nicknamed by some teachers 'NorwEnglish' or even 'No-English' and ridiculed in the media (e.g. Herseth, 2009). Norwegian was included as an alternative because it was considered a familiar accent label to the participants, but due to its relative stigma we did not expect many participants to report it as their preferred pronunciation. In addition to Norwegian and the non-committal options Other and I don't care, 'Neutral' was given as an alternative following pilot studies and conversations with speakers of the same age, who reported that instead of 
aiming towards any of the well-known native accents, they preferred a 'neutral' English accent. In order to explore the rationale for a 'neutral' accent aim further, focus-group interviews with participants with this accent aim were held at each school, following the recordings and administration of the questionnaire. A detailed analysis of the interviews is beyond the scope of this article, but quotes from one interview (School C) are included to illuminate the quantitative data. Interviews were held in Norwegian and quotes are translated into English by the first author. When asked to define 'neutral' English, one participant gave the following response:

you pronounce it based on how it sounds in your head, like, naturally, not that you, like, change it to sound more British or more American. It's actually just reading and talking the way that feels natural to you

What is natural to these L2 speakers might be related to L2 exposure and social evaluations of available linguistic resources. The social evaluations of L2 and motivations for a 'neutral' English aim are discussed below in A 'neutral' variety of English?.

Table 4 gives an overview of the participants' accent aims as reported in the questionnaire. Three participants were absent when the questionnaire was administered. One participant (here in the Other category) circled both British and American and wrote "It can be useful to learn both".

Table 4. The participants' reported accent aim

\begin{tabular}{cccccc}
\hline British & American & 'Neutral' & Norwegian & Other & I don't care \\
\hline 23 & 29 & 10 & 0 & 2 & 3 \\
\hline
\end{tabular}

$75 \%$ of the participants chose one of the native accents as their accent aim. American English was the most popular. Not a single participant reported Norwegian English as their accent aim, but ten students reported to aim towards a 'Neutral' accent. Participants will here be referred to as American English (AmE) aimers, British English (BrE) aimers and Neutral aimers, based on their accent aims.

Figure 2 shows that the production results by accent aim reveal significant differences between the three main groups. One-way ANOVA with Post-Hoc Bonferroni shows that these differences are significant for BATH, LOT, GOAT, Non-prevocalic /r/ and Intervocalic /t/. The differences are significant only between AmE aimers and BrE aimers, not between Neutral aimers and either of the native accent aimers. 
BATH

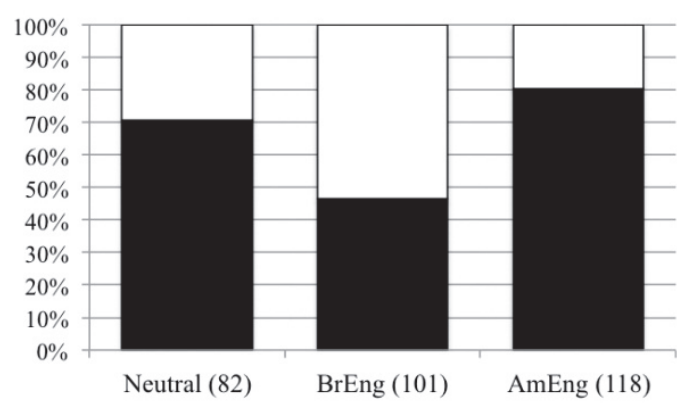

GOAT

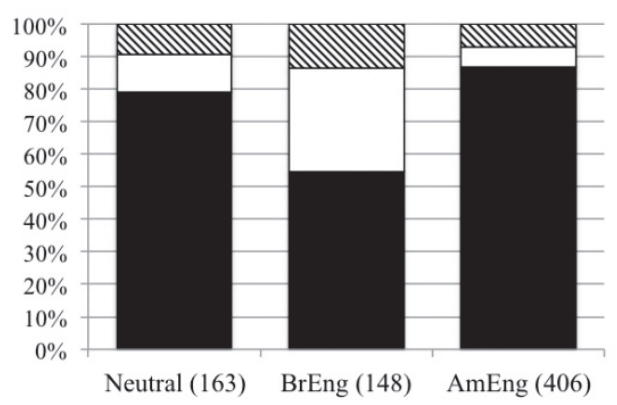

INTERVOCALIC / $/$ /

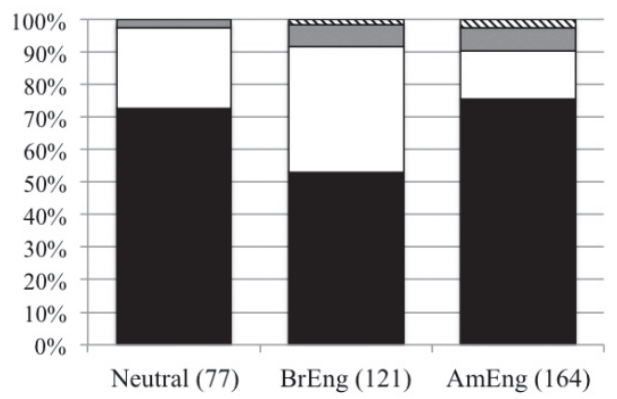

VOICELESS th

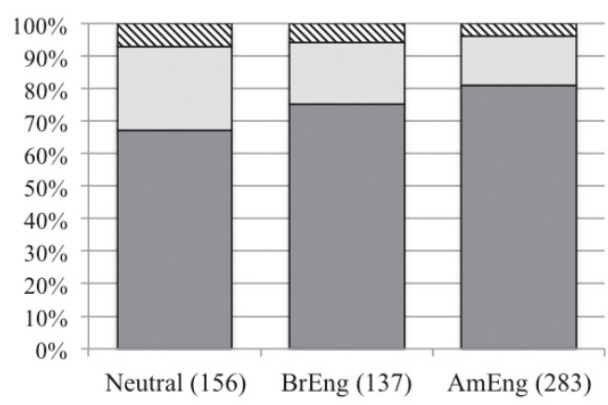

$\square_{\mathrm{t}}$

$\square \theta$
LOT

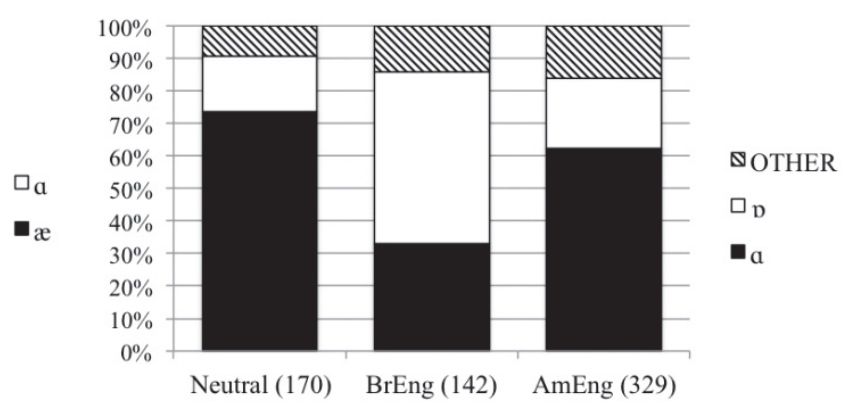

NON-PREVOCALIC /r/

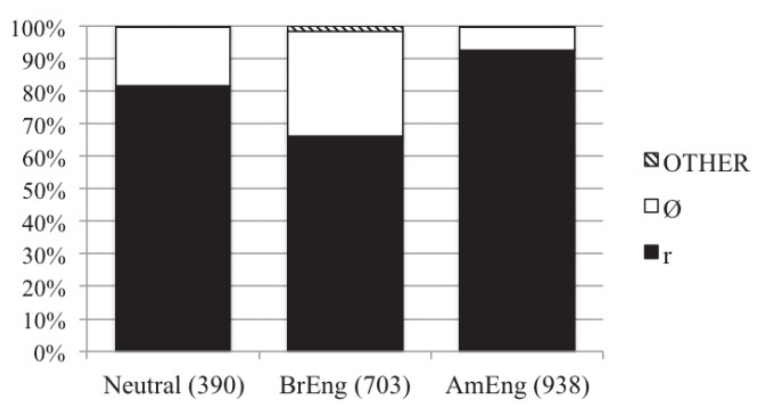

POST-CORONAL /j/

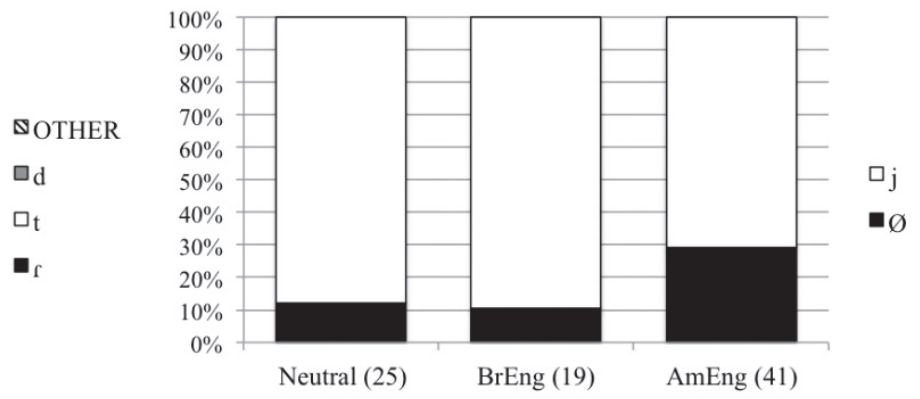

\$OTHER

Figure 2. The production of seven variables in conversational speech by speakers' reported accent aim

The results show that to a certain degree both AmE aimers and BrE aimers produced variants found in their targeted variety of English. For BATH, AmE aimers used more [æ] and less [a] than BrE aimers in both the word list $(\mathrm{p}<0.001)$, and conversational speech $(\mathrm{p}<0.01)$. For LOT, BrE aimers used more [p] and less [a] than AmE aimers in both speech situations 
$(\mathrm{p}<0.001)$. For GOAT, BrE aimers had less back [o-] and more front [ə-] onsets than AmE aimers $(\mathrm{p}<0.01)$ in the word list. For Non-prevocalic $/ \mathrm{r} /$, all the accent aimers were variably rhotic but AmE aimers were more rhotic than BrE aimers in both the word list $(p<0.05)$ and conversational speech $(\mathrm{p}<0.01)$. Finally, for Intervocalic $/ \mathrm{t} /$, those aiming towards AmE used more $[\mathrm{r}]$ and less $[\mathrm{t}]$ than BrE aimers for word list speech $(\mathrm{p}<0.05)$. For Post-coronal $/ \mathrm{j} /$ and Voiceless th no significant differences were found between the three accent aims. Postcoronal $/ \mathrm{j} /$ has not been described as a salient difference in pronunciation between GenAm and SSBE, and the results suggest that this feature is not salient to the participants either. Voiceless th was included to investigate possible patterns of L1 influence, but participants seemed to be treating this variable similarly regardless of accent aim.

\section{DISCUSSION}

\section{Hybridity and variation}

Most of the realisations of phonological variables among the Norwegian adolescents could be identified as variants which can be found in native British English or American English accents. This does not mean that all variants are entirely native-like without influence from one or more home languages. However, analyses of the only variable with an expected L1influenced variant, Voiceless $t h$, showed the native-English fricative realisation to be the most prominent. Furthermore, there was no evidence of heavily L1-influenced pronunciation; rhotic variants of Non-prevocalic / $\mathrm{r}$ / and tapped variants of Intervocalic / $\mathrm{t}$ / were dominant in the participants' production, even though these are not relevant realisations of $/ \mathrm{r} /$ and $/ \mathrm{t} /$ in the L1. Even so, there is naturally more variation in L2 pronunciation than is presented within the scope of this study, which calls for further and more narrow phonetic investigations.

The overall realisation of English phonological variables is characterised by a majority of English variants that are also found in American English. This suggests that the adolescents are not strongly influenced by their teacher's accent, since these had variable patterns of production, and because school did not have any effect on production (cf. Overall results). As suggested by Rindal (2010), the logical alternative explanation for the students' patterns is that they are influenced by daily exposure to English language media, which is dominated by American English. Nevertheless, despite considerable American English influence, speakers' realisations of variables aligned with their reported accent aims. Speakers who reported to aim towards a British English pronunciation used lower levels of AmE features than AmE aimers for all variables, and significantly so for the variables which are salient in differentiating between these two native accents. This implies that the L2 speakers to a certain degree used 
the pronunciation they aimed towards, and suggests a high level of L2 awareness and competence.

Although the production results suggest an overall AmE preference, most speakers used more than one variant for each variable, resulting in considerable intra-speaker variation. The overall speaker pattern is thus a blended use of variants from native English varieties, with some additional pronunciations, forming a hybrid and variable L2 accent. The lack of variation across the social factors of gender, school and home language, though granted in an academically-oriented environment, suggests that the participants constitute an L2 community with shared English linguistic practices. However, this lack of variation between demographic categories also means there is no obvious surface pattern in the variation. As opposed to postcolonial 'New Englishes' (cf. Introduction), L2 production in Norway cannot be accounted for by contact processes and language-historical developments. The hybrid English accent in Norway reflects a transitional L2 situation, in which individual speakers' language choices might better account for the language variation.

\section{A 'neutral' variety of English?}

Although the majority of participants reported to aim towards a native variety of English, a large minority reported a 'neutral' accent aim. For all variables except LOT and Voiceless th, Neutral aimers used less of the features found in AmE than AmE aimers, but more than BrE aimers. Neutral aimers have thus positioned themselves in between in the traditional BrE/AmE dichotomy. Speaker commentary from the focus-group interviews suggests that native accents are associated with values and attributes that learners of English might not wish to convey:

I think many of us want to be neutral because I want to, like, be thought of as someone who actually knows the language (...) I don't want to, like, be thought of as an American or a Brit (Neutral aimer)

The wish to avoid native speaker associations is in line with Rindal (2010), who found that Norwegian learners not only evaluate English accents, but also each other based on the English accent they use: Standard Southern British English is assigned a formal function by learners, related to competence and school, while General American is assigned an informal function and regarded as more available because of considerable media exposure. The strategy for the Neutral aimers in the present study seems to be an attempt to avoid the associations related to native varieties by not aiming towards any recognisable English accent: 
I speak, in a way, what I've learnt and what I've picked up, a little here and a little there (Neutral aimer)

The evasion of native English accents as L2 standards might be facilitated and even encouraged by the general sociolinguistic climate in Norway. In a language society with considerable acceptance towards spoken variation (cf. English in Norway), where using one's own dialect is encouraged and there is no tradition to target a standard (Sandøy, 2011; Vikør, 2006), targeting an L2 standard might not be a priority among speakers either. The absence of a strong standard ideology in Norway might allow learners to use linguistic resources from more than one English variety in a hybrid L2 accent. However, none of the participants reported Norwegian as their English pronunciation aim, which suggests that speakers retain some notion of 'correct' (or at least 'incorrect') English. Furthermore, what the participants have 'picked up' seems to be mostly AmE features. Although Neutral aimers are positioned in between AmE and BrE aimers, there is a tendency for Neutral aimers' production to be closer to AmE aimers than BrE aimers (cf. Figure 2). For LOT, Neutral aimers even produce more AmE features than AmE aimers. The high levels of AmE phonological features in general and among Neutral aimers in particular, suggest that linguistic forms from this variety are more available to Norwegian adolescents.

\section{CONCLUSIONS}

Although the World Englishes paradigm encourages local appropriation and hybridity, early World Englishes perspectives (e.g. Kachru, 1992) have been criticised for constructing English speakers' identity according to their nationality, and for privileging native speakers over second language users, and second language users over foreign language users (e.g. Graddol, 2006; Pennycook, 2005). More recently, ELF scholars are more concerned with the fluidity of language and argue to abandon the traditional variety restriction (Jenkins et al., 2011). The results of this study suggest that the Norwegian participants to a certain extent abandon traditional variety restrictions and native speaker privilege by aiming towards a 'neutral' variety of English and avoiding the formal school-associated British English accent. In an L2 context where the role of English is characterised by transition and hybridity, Norwegian learners' L2 strategies seem also to be characterised by hybridity and negotiation, even for speakers who aim towards native accents of English. In this ELT context, factors such as media influence, language attitudes and language choices seem to better account for patterns in the L2 variation than World Englishes and ELF frameworks. However, similarly to the indigenised Englishes in postcolonial countries, English is also localised in this ELT 
environment, contributing to the increasing diversity in the development of English as a global language. More research is needed into the local uses of English in ELT contexts, especially into individual speaker strategies such as stylistic practice and speaker accommodation, in order to form an accumulated impression of the diversity of English as a global language. Also, more research is needed specifically into the intra-variant variation of L2 speakers, for instance the degree of rhoticity and duration of vowels, which was beyond the scope of the present study, in order to form an impression of the local appropriations of English. The results in this study encourage the further application of sociolinguistic methods when investigating the appropriation of English in L2 environments.

The varying L2 strategies among Norwegian learners not only reflect their access to various linguistic and semantic resources, but also the political-ideological climate in which they practice language. In a society with relative acceptance of spoken variation, where speakers are not accustomed to targeting a standard in their L1, it also seems possible for the L2 to be characterised by variation and for speakers to dismiss standard models. The results of this study consequently strengthen the established characterisations of the Norwegian society as linguistically tolerant. The L2 practices presented here are in line with ELF perspectives, where the target model of English is not a native speaker, but a fluent bilingual speaker, who can communicate with other non-native speakers of varying proficiency, and still be able to express national and individual identity through English. Therefore, the lack of a nativespeaker accent should not be seen as a sign of poor competence among L2 speakers. However, the dismissal of a standard, reflected in the lack of explicit target models in the national English language curriculum, creates a demand for guidance related to English pronunciation, and teachers are left with the responsibility to present and discuss with students the status and diversity of English. Consequently, teacher education in Norway and other countries with similar English language conditions have a responsibility to make available recent and relevant research on English in the complex and globalising world, so that teachers can better meet the language needs among their learners, and if necessary, (re)consider how they think about language and English. 


\section{NOTES}

${ }^{1}$ Our thanks to Andy Maul, Andreas Lund, Unn Røyneland and Paul Foulkes for comments on previous drafts of this paper. We are also grateful for constructive and valuable comments from two anonymous reviewers for World Englishes.

${ }^{2}$ Apart from this citation from the general English syllabus, the citations are taken from the syllabus for the programme subject International English, of which the participants were students at the time of the study. A detailed analysis of the syllabus is beyond the scope of this article; the citations serve as examples of the English language view professed by educational authorities.

${ }^{3} 44,5 \%$ of students in Oslo and $42,5 \%$ in Norway who finish upper secondary school go directly on to higher education (Statistics Norway, 2011). This number is expected to be much higher, though, since many students do military service or have time off before proceeding to higher education.

${ }^{4}$ The percentages presented here represent the overall production for all speakers combined, no matter the number of tokens per speaker. Therefore, the mean number of tokens for the six variables that differentiate GenAm from SSBE (excluding Voiceless $t h$ ) were calculated for each speaker, and compared with the distribution of the token counts by speaker frequency. The calculation showed that the mean number of tokens per speaker coincided with the peak of the token distribution, indicating that the data is not being skewed by any speakers with token counts falling far beyond a normal distribution. The statistical tests presented with Figures 1 and 2, however, are performed with percentages of variant realisation per speaker.

\section{REFERENCES}

Bonnet, G. (2004). The assessment of pupils' skills in English in eight European countries 2002. Paris: The European Network of Policy Makers for the Evaluation of Education Systems.

Coupland, N. (2007). Style: Language variation and identity. Cambridge: Cambridge University Press. Cruttenden, A. (2008). Gimson's Pronunciation of English (7th ed.). London: Hodder Education.

Dalton-Puffer, C., Kaltenboeck, G., \& Smit, U. (1997). Learner attitudes and L2 pronunciation in Austria. World Englishes, 16(1), 115-128.

Eckert, P. (2012). Three waves of variation study: The emergence of meaning in the study of sociolinguistic variation. Annual Review of Anthropology, 41, 87-100.

Education Act, Act of 17 July 1998 no. 61 relating to Primary and Secondary Education and Training. Education First. (2011). EF English Proficiency Index.

Foulkes, P. (2006). Phonological variation: A global perspective. In B. Aarts \& A. McMahon (Eds.), The handbook of English linguistics (pp. 625-669). Oxford: Blackwell.

Graddol, D. (2006). English next. London: The British Council.

Graedler, A.-L. (2002). Norwegian. In M. Görlach (Ed.), English in Europe (pp. 57-81). Oxford: Oxford University Press.

Herseth, S. K. (2009). Engelsklærer vil bruke Jagland-tale i undervisningen [English teacher wants to use Jagland speech in class], Dagbladet. Retrieved from http://www.dagbladet.no/2009/12/10/nyheter/innenriks/obama/fredspris/jagland/9445365/

ITU Monitor. (2009). The digital state of affairs in Norwegian schools 2009: The Network for IT Research and Competence in Education (ITU).

Jenkins, J. (2006). Current perspectives on teaching World Englishes and English as a Lingua Franca. TESOL Quarterly, 40(1), 157-181.

Jenkins, J., Cogo, A., \& Dewey, M. (2011). Review of developments in research into English as a lingua franca. Language Teaching, 44(3), 281-315.

Kachru, B. (1992). World Englishes: Approaches, issues, and resources. Language Teaching, 25, 1-14.

Kachru, B., Kachru, Y., \& Nelson, C. (Eds.). (2006). The handbook of World Englishes. Malden, MA: Blackwell. 
KD. (2006). National Curriculum for Knowledge Promotion in Primary and Secondary Education and Training. Oslo: Ministry of Education and Research Retrieved from http://www.udir.no/Stottemeny/English/Curriculum-in-English/.

Kirkpatrick, A. (2010a). Introduction. In A. Kirkpatrick (Ed.), The Routledge handbook of World Englishes. London: Routledge.

Kirkpatrick, A. (Ed.). (2010b). The Routledge handbook of World Englishes. London: Routledge.

Kristiansen, T., \& Vikør, L. S. (2006). Nordiske språkhaldningar - jamføring og konklusjonar [Nordic language attitudes - summary and conclusions]. In T. Kristiansen \& L. S. Vikør (Eds.), Nordiske språkhaldningar. Ei meiningsmåling [Nordic language attitudes. A survey] (pp. 199214). Oslo: Novus.

Kristoffersen, G. (2000). The phonology of Norwegian. Oxford: Oxford University Press.

Ladegaard, H., J. (1998). National stereotypes and language attitudes: The perception of British, American and Australian language and culture in Denmark. Language and Communication, $18(4), 251-274$.

Ljosland, R. (2010). Teaching through English: monolingual policy meets multilingual practice. Hermes - Journal of Language and Communication Studies, 45, 99-113.

Pennycook, A. (2005). Global and worldly Englishes: Discommunities and subcultural empires. Paper presented at the Institute of European Studies, Berkely, CA, February, Berkely, CA.

Piercy, C. (2010). One la/ or two?: The phonetics, phonology and sociolinguistics of change in the TRAP and BATH vowels in the southwest of England. PhD thesis, University of Essex.

Rindal, U. (2010). Constructing identity with L2: Pronunciation and attitudes among Norwegian learners of English. Journal of Sociolinguistics, 14(2), 240-261.

Roach, P., Setter, J., \& Esling, J. (Eds.). (2011) Cambridge English Pronouncing Dictionary Daniel Jones (18th ed.). Cambridge: Cambridge University Press.

Røyneland, U. (2009). Dialects in Norway - catching up with the rest of Europe? International Journal of the Sociology of Language, 196/197, 7-31.

Sandøy, H. (2007). Avisspråket i Norden - ei jamføring [The newspaper language in the Nordic countries - a summary]. In B. Selback \& H. Sandøy (Eds.), Fire dagar i nordiske aviser [Four days in Nordic newspapers] (pp. 127-155). Oslo: Novus.

Sandøy, H. (2011). Language culture in Norway: A tradition of questioning standard language norms. In T. Kristiansen \& N. Coupland (Eds.), Standard languages and language standards in a changing Europe. Oslo: Novus Press.

Schneider, E. W. (2010). Developmental patterns of English - similar or different? In A. Kirkpatrick (Ed.), The Routledge handbook of World Englishes. London and New York: Routledge.

Seidlhofer, B. (2011). Understanding English as a lingua franca. Oxford: Oxford University Press.

Seidlhofer, B., \& Berns, M. (2009). Perspectives on English as a lingua franca: Introduction. World Englishes, 28(2), 190-191.

Selback, B., \& Kristiansen, T. (2006). Noreg [Norway]. In T. Kristiansen (Ed.), Nordiske sprogholdninger. En masketest [Nordic language attitudes. A matched-guise test] (pp. 65-82). Oslo: Novus.

Shockey, L. (1984). All in a flap: long term accommodation in phonology. International Journal of the Sociology of Language, 46, 87-95.

Språkrådet. (2011). Språkstatus 2011: Språkpolitisk tilstandsrapport fra Språkrådet: Språkrådet (The Language Council of Norway).

Statistics Norway. (2011). Table 06428. Retrieved 27.09.2012 http://www.ssb.no/english/

Tollfree, L. (1999). South East London English: Discrete versus continuous modelling of consonantal reduction. In P. Foulkes \& G. J. Docherty (Eds.), Urban voices (pp. 163-184). London: Arnold.

Tottie, G. (2002). An introduction to American English. Oxford: Blackwell.

Trudgill, P. (1986). Dialects in contact. Oxford: Basil Blackwell.

Vikør, L. S. (2006). Noreg [Norway]. In T. Kristiansen \& L. S. Vikør (Eds.), Nordiske språkhaldningar. Ei meiningsmåling [Nordic language attitudes. A survey] (pp. 61-84). Oslo: Novus. 


\section{APPENDIX 1: The word list task}

$\begin{array}{lll}\text { lemon } & \text { light } & \text { goat } \\ \text { college } & \text { whatever } & \text { corn } \\ \text { student } & \text { stupid } & \text { ice } \\ \text { dance } & \text { leave } & \text { Tuesday } \\ \text { army } & \text { classroom } & \text { mighty } \\ \text { twenty } & \text { fire } & \text { boat } \\ \text { top } & \text { bottom } & \text { plenty } \\ \text { drink } & \text { moment } & \text { glass } \\ \text { eight } & \text { possible } & \text { knowledge } \\ \text { new } & \text { meal } & \text { paint } \\ \text { atom } & \text { invented } & \text { Wednesday } \\ \text { sister } & \text { fast } & \text { time } \\ \text { code } & \text { alright } & \\ \text { wanted } & \text { fatal } & \end{array}$

APPENDIX 2: The number of tokens by variable and task

\begin{tabular}{llll}
\hline Variable & Example & N Word List & N Conversation \\
\hline BATH & fast, dance & 280 & 346 \\
LOT & top, college & 280 & 868 \\
GOAT & code, boat & 280 & 972 \\
Non-prevocalic $/ \mathrm{r} /$ & car, party & 280 & 2280 \\
Intervocalic $/ \mathrm{t} /$ & mighty, better & 209 & 396 \\
Post-coronal $/ \mathrm{j} /$ & new, student & 280 & 123 \\
Voiceless $t h$ & think, earth & - & 782 \\
\hline Total & & 1609 & 5767 \\
\hline
\end{tabular}


APPENDIX 3: The overall production for each variable in conversational speech

\begin{tabular}{|c|c|c|c|c|}
\hline Variable & Total N & Variants & $\mathbf{N}$ & $\%$ \\
\hline \multirow{2}{*}{ BATH } & \multirow{2}{*}{346} & $æ$ & 236 & 68 \\
\hline & & $\mathrm{a}$ & 110 & 32 \\
\hline \multirow{3}{*}{ LOT } & \multirow{3}{*}{868} & $a$ & 485 & 56 \\
\hline & & $\mathrm{p}$ & 258 & 30 \\
\hline & & OTHER & 125 & 14 \\
\hline \multirow{3}{*}{ GOAT } & \multirow{3}{*}{972} & o- & 787 & 81 \\
\hline & & ว- & 115 & 12 \\
\hline & & OTHER & 70 & 7 \\
\hline \multirow{3}{*}{ Non-prevocalic /r/ } & \multirow{3}{*}{2280} & $\mathrm{r}$ & 1871 & 82 \\
\hline & & $\varnothing$ & 392 & 17 \\
\hline & & OTHER & 17 & 1 \\
\hline \multirow{4}{*}{ Intervocalic /t/ } & \multirow{4}{*}{396} & I & 268 & 68 \\
\hline & & $\mathrm{t}$ & 94 & 24 \\
\hline & & $\mathrm{d}$ & 27 & 7 \\
\hline & & OTHER & 7 & 2 \\
\hline \multirow{2}{*}{ Post-coronal /j/ } & \multirow{2}{*}{123} & $\varnothing$ & 28 & 23 \\
\hline & & $\mathrm{j}$ & 95 & 77 \\
\hline \multirow{3}{*}{ Voiceless $t h$} & \multirow{3}{*}{782} & $\theta$ & 597 & 76 \\
\hline & & $\mathrm{t}$ & 130 & 17 \\
\hline & & OTHER & 55 & 7 \\
\hline
\end{tabular}


APPENDIX 4: Significant effects of independent variables school, gender and home language on production

\begin{tabular}{|c|c|c|c|}
\hline $\begin{array}{l}\text { Independent } \\
\text { variable }\end{array}$ & $\begin{array}{l}\text { Statistical test } \\
\text { (SPSS) }\end{array}$ & $\begin{array}{l}\text { Linguistic } \\
\text { variable }\end{array}$ & Significant correlations \\
\hline School & $\begin{array}{l}\text { One-way } \\
\text { ANOVA with } \\
\text { Post-Hoc } \\
\text { Bonferroni }\end{array}$ & BATH & $\begin{array}{l}\text { - School C used more }[æ] \text { than } \\
\text { Schools A and B in conversations } \\
(p<0.05)\end{array}$ \\
\hline Gender & $\begin{array}{l}\text { Independent } \\
\text { samples t-test }\end{array}$ & LOT & $\begin{array}{l}\text { - Females used more }[a] \text { than males } \\
\text { in word list }(p<0.05) \\
\text { - Females used more }[a] \text { than males } \\
\text { in conversations }(p<0.001) \\
\text { - Males used more OTHER variants } \\
\text { than females in conversations } \\
(p<0.05)\end{array}$ \\
\hline $\begin{array}{l}\text { Home } \\
\text { language }\end{array}$ & $\begin{array}{l}\text { Independent } \\
\text { samples t-test }\end{array}$ & BATH & $\begin{array}{l}\text { - Students with another/additional } \\
\text { L1 used more [æ] than students } \\
\text { with Norwegian as only L1 in } \\
\text { word list }(\mathrm{p}<0.05) \\
\text { - Students with Norwegian as only } \\
\text { L1 used more OTHER variants } \\
\text { than students with } \\
\text { another/additional L1 in } \\
\text { conversations ( }<<0.05)\end{array}$ \\
\hline
\end{tabular}






\section{Errata}

- headers are added throughout the thesis

- p. IV, last paragraph, last line:

"Awaiting editor decision for World Englishes" changed to "In press for World Englishes"

- p. $18,1^{\text {st }}$ paragraph, line 4 :

"does not concern" changed to "is not concerned with"

- p. $21,2^{\text {nd }}$ paragraph, line 4:

"General American" changed to "American"

- p. 65 , footnote, line 1:

"students" changed to "students in Norway"

- p. 66, $2^{\text {nd }}$ paragraph, lines 12 and 14 :

"remains" changed to "remnants"

- p. 83, line 13:

"Second language" changed to "Second (additional) language"

- p. $94,1^{\text {st }}$ paragraph, line 1 :

"Article 3" changed to "Article 1"

- p. $94,1^{\text {st }}$ excerpt, heading:

"in Article 1 and in Article 2" changed to "and in Articles 2 and 3"

- p. 94, $2^{\text {nd }}$ excerpt, heading:

"Article 2" changed to "Article 3"

- p. $95,1^{\text {st }}, 2^{\text {nd }}$ and $3^{\text {rd }}$ excerpts, headings:

"Article 3" changed to "Article 1"

- p. $97,1^{\text {st }}$ excerpt, heading:

"Articles 1 and 2" changed to "Articles 2 and 3"

- p. $97,2^{\text {nd }}$ excerpt, heading:

"Article 3" changed to "Article 1"

- p. $98,1^{\text {st }}$ and $2^{\text {nd }}$ excerpts, headings:

"Article 3" changed to "Article 1"

- A few minor typographical errors have been corrected throughout the thesis 